\title{
5
}

\section{Tectonics, Magmatism, and Evolution of the New Hebrides Backarc Troughs (Southwest Pacific)}

\author{
Patrick Maillet, Etienne Ruellan, Martine Gérard, Alain Person, \\ Hervé Bellon, Joseph Cotten, Jean-Louis Joron, Setsuya Nakada, \\ and Richard C. Price
}

\section{ABSTRACT}

In the southwest Pacific, a discontinuous series of narrow and elongated troughs separates the New Hebrides island arc from the adjacent active marginal basin, the North Fiji Basin. This chapter reviews the structural, geophysical, geochronological, and petrological data available for the New Hebrides backarc troughs (NHBAT) and discusses the significance of these structures.

A diffuse horst-and-graben morphology, partly obscured in some places by recent volcanic complexes, characterizes the northern Jean-Charcot troughs (JCT). By contrast, the southern Coriolis troughs (CT) show well-developed flat-bottomed grabens. Moreover, no backarc troughs are observed in the central backarc area, adjacent where the d'Entrecasteaux zone collides with the arc.

Volcanic rocks dredged in the NHBAT show a wide range of $\mathrm{SiO}_{2}$ contents, with high$\mathrm{Al}_{2} \mathrm{O}_{3}$ and low- $\mathrm{TiO}_{2}$ contents, features typical of their arc/backarc environments. Trace element analyses indicate a much stronger subduction component in the volcanics of the southern CT than in those of the northern JCT. However, large-ionic-radius-lithophileelement (LILE) (Ba, Rb, Sr) enrichments and high-field-strength-elements (HFSE) (Ta, Nb, $\mathrm{Zr}, \mathrm{Ti}, \mathrm{Y}, \mathrm{Yb}$ ) depletions, relative to $\mathrm{N}-\mathrm{MORB}$ (mid-ocean ridge basalts), are generally observed in most NHBAT volcanics and are features characteristic of island-arc basic and

Patrick Maillet • ORSTOM Centre de Brest-GDR "GEDO” 910, 29280 Plouzané, France. Etienne Ruellan - CNRS Sophia-Antipolis, 06560 Valbonne, France. Martine Gérard - ORSTOM, 93143 Bondy, France. Alain Person - Laboratoire de Géologie des Bassins Sédimentaires, Université Pierre et Marie Curie, 75252 Paris, France. Hervé Bellon and Joseph Cotten - CNRS URA 1278-GDR "GEDO" 910, Université de Bretagne Occidentale, 29287 Brest, France. Jean-Louis Joron • Groupe des Sciences de la Terre, Laboratoire Pierre-Suie, CEN Saciay, 91191 Gif sur Yvette, France. Setsuya Nakada - Kyushu University, Fukuoka 812, Japan. Richard C. Price - La Trobe University, Bundoora, Victoria 3083, Australia.

Backarc Basins: Tectonics and Magmatism, edited by Brian Taylor, Plenum Press, New York, 1995. 
intermediate volcanics. Backarc basin basalts (BABB) are scarce; the only occurrence was found in the very northern JCT, indicative of an aborted tendency toward oceanic spreading, between 3.9 and $1.1 \mathrm{Ma}$ (K/Ar dating).

Geological long-range inclined asdic (GLORIA) seafloor imagery, manned submersible observations, water chemistry analyses, and sediment heat flow measurements do not provide evidence for widespread hydrothermal activity, or oceanic spreading, in the NHBAT. However. some ferromanganese crusts coating volcanic and volcano-sedimentary formations have a hydrothermal origin (todorokite, birnessite, phillipsite). These hydrothermal crusts are mainly located on the eastern faulted border of the NHBAT.

The volcanic-tectonic evolution of the New Hebrides backarc troughs primarily results from the concomitant effects of nearby subduction (along the New Hebrides subduction zone) and spreading (in the central North Fiji basin) and secondarily from the after-effects of the collision of the d'Entrecasteaux zone with the arc. The NHBAT represent the very first stage of backarc crustal extension, characterized by volcanics with predominantly island-arc tholeiite and some BABB compositional features.

\section{INTRODUCTION}

Located between an island arc and a marginal basin, backarc troughs may record the concomitant or successive influences of crustal distension, rifting, oceanic spreading, with or without any arc-induced magmatic contamination. A number of recent papers have discussed the structural, petrological, and geochronological characteristics of the New Hebrides backarc troughs (Récy et al. 1986, 1990; Monjaret et al., 1987, 1991; Charvis and Pelletier, 1989; Monjaret, 1989: Sage and Charvis, 1991; Matsumoto et al., 1992: Johnson et al., 1993; Pelletier et al., 1993b; Price et al., 1993; Nakada et al., 1994). Yet the significance of these troughs in the regional tectonic framework of the southwest Pacific remains controversial. Do these troughs represent old and inactive structures or incipient spreading features - that is, a nascent backarc basin with recent active submarine volcanism? Is their formation primarily linked to the evolution of the New Hebrides island arc or to that of the North Fiji Basin?

To answer these questions, we review and discuss available data on the New Hebrides backarc troughs and propose a new interpretation accounting for the occurrence of these unusual submarine structures.

\section{GEOLOGICAL AND TECTONIC FRAMEWORK OF THE NEW HEBRIDES ISLAND ARC AND THE NORTH FIJI BASIN}

In the area between $10^{\circ} \mathrm{S}$ and $25^{\circ} \mathrm{S}$ and $165^{\circ} \mathrm{E}$ and $170^{\circ} \mathrm{W}$. two subduction zones with opposite directions of convergence dip toward each other (Fig. 5.1). Along the New Hebrides subduction zone (i.e., beneath the Santa Cruz, or the eastern outer Solomon, and Vanuatu islands), the consumption of the India-Australia plate is marked by a rapid subduction in an E-NE direction $\left(9-16 \mathrm{~cm} / \mathrm{yr} ; \mathrm{N} 76^{\circ} \mathrm{E} \pm 11\right.$; dip $70^{\circ}$ ). Along the Tonga subduction zone, the geodynamic scheme is almost symmetrical for the subducting Pacific plate $\left(16.5-18 \mathrm{~cm} / \mathrm{yr}\right.$ along a W-NW direction, with a dip of $80^{\circ}$ ) (Isacks et al., 1981; Louat et al., 1988: Louat and Pelletier, 1989; Pelletier and Louat, 1989: Pelletier and Dupont, 1990a). 


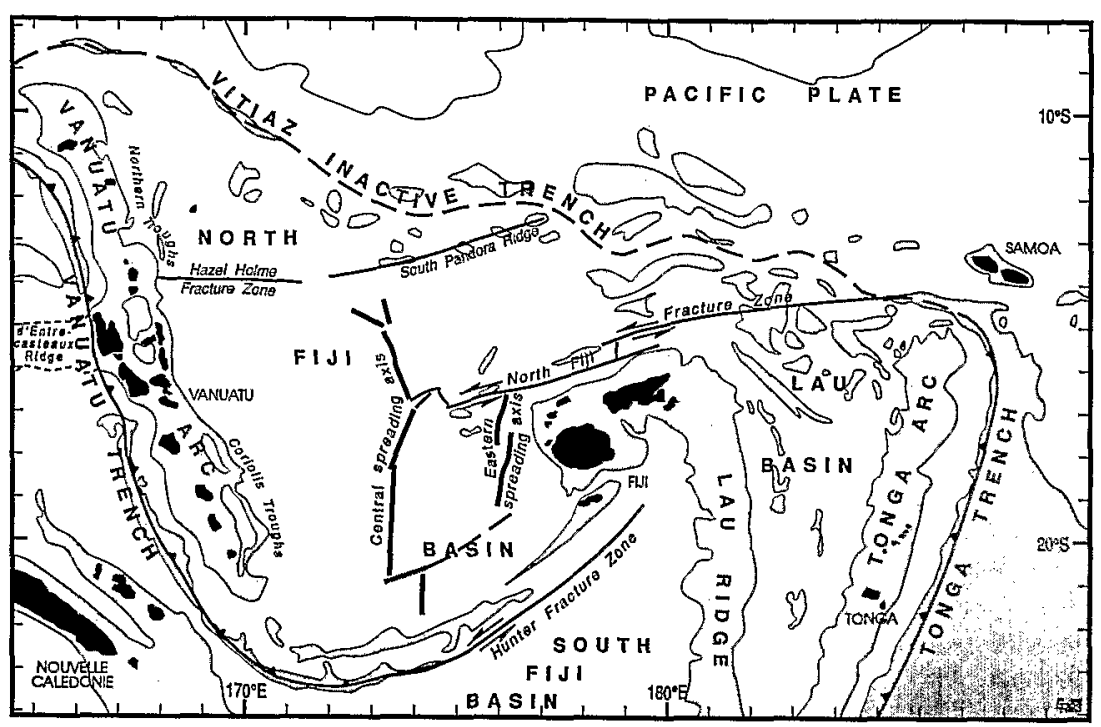

FIGURE 5.1. Tectonic setting of the New Hebrides (Vanuatu) arc in the southwest Pacific. Northern troughs = Jean-Charcot troughs (JCT) in the text.

Plate consumption along these two subduction zones is accompanied by the opening of two active marginal basins: the North Fiji Basin, between Vanuatu and Fiji (Auzende et $a l$., Chapter 4 this volume), and the Lau Basin, between Fiji and Tonga (Hawkins, Chapter 3 this volume).

Interestingly, both subduction zones are affected by the collision of major submarine ridges. The d'Entrecasteaux zone is colliding with the central New Hebrides arc, and the collision zone is moving northward (Maillet et al., 1983; Collot et al., 1985; 1992a,b), whereas the Louisville Ridge is colliding with and sweeping southward along the Tonga arc (Dupont and Herzer, 1985; Pelletier and Dupont, 1990b; Lallemand et al., 1992).

\subsection{The New Hebrides Island Arc}

The New Hebrides island arc comprises three volcanic chains (Carney et al., 1985): a western belt (late Oligocene to middle Miocene) forming the islands of the Torres Group, Espiritu Santo and Malakula; an eastern belt (late Miocene to early Pliocene), including the islands of Maewo and Pentecost; and a central chain (late Miocene to Holocene), which runs more than $1500 \mathrm{~km}$ from Tinakula-Nendo (Santa Cruz Islands) in the north to Matthew and Hunter volcanoes in the south (Fig. 5.2).

The following summary is from Macfarlane et al. (1988) and Gorton (1974, 1977).

\subsubsection{Western Belt}

Volcanism in the islands of the Torres Group, Espiritu Santo and Malakula, commenced in latest Oligocene time but occurred largely during the early to middle Miocene (25-14 Ma), along the former Vitiaz island arc, overlying a southwest dipping Benioff zone. Petrographically, lavas of the western belt range from olivine basalt to hornblende- 


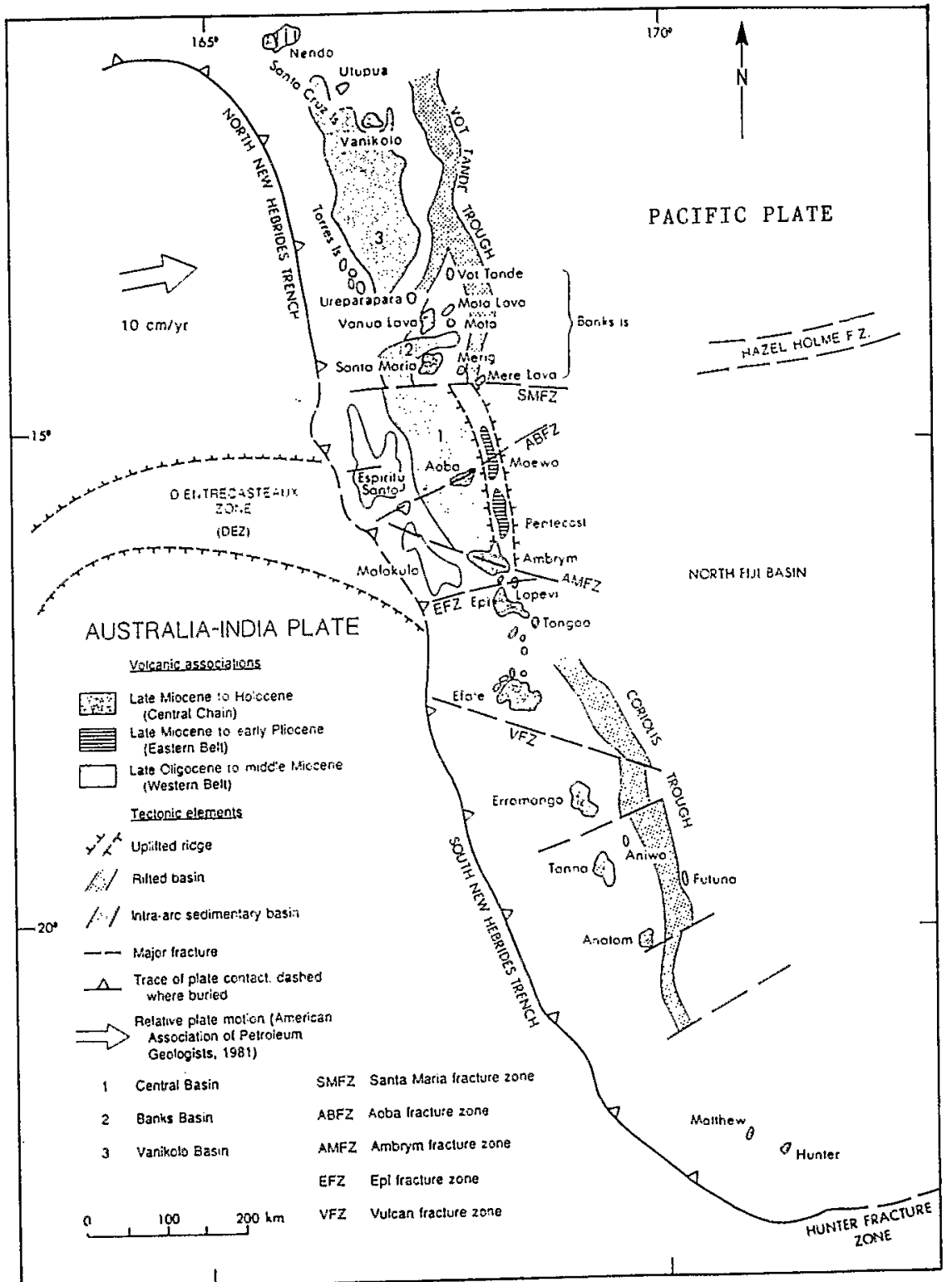

FIGURE 5.2. The principal geological and tectonic features of the New Hebrides island arc iafter Greene et al. 1988a). Vot Tande truugh = Jean-Charcot troughs (JCT) in the text.

bearing dacite and rhyodacite pumice, but andesite (including both two-pyroxene and hornblende-phyric varieties) is most abundant.

The western belt lavas show transitional calc-alkaline/tholeiitic characteristics and in this respect resemble the Lau Ridge volcanics and lavas from the lower- $\mathrm{K}_{2} \mathrm{O}$ suite presently erupting in the New Hebrides arc central chain. 


\subsubsection{Eastern Belt}

The island of Pentecost is the only island of the New Hebrides arc on which a basement complex crops out. This is composed of slices of ultramafic to basaltic rocks interpreted as a fragmented ophiolite, possibly representing sections of the oceanic crust upon which the eastern belt arc volcanics accumulated. Most of these rocks are too altered and metamorphosed for $\mathrm{K} / \mathrm{Ar}$ dating and have low $\mathrm{K}_{2} \mathrm{O}$ contents. Still, two mineral $\mathrm{K} / \mathrm{Ar}$ ages ( $35 \pm 2 \mathrm{Ma}$ for a hornblende from an amphibolite, and $28 \pm 6 \mathrm{Ma}$ for a plagioclase from a gabbro) place younger limits on the age of this basement (Gorton, 1974).

Most of the Maewo and Pentecost volcanics erupted between late Miocene and lowermiddle Pliocene time (7-5 Ma for Maewo, 6-3 Ma for Pentecost) from submarine fissures. Pillow lavas, associated intrusions, and pyroclastic rocks range in composition from basal ankaramites, picrites, and mafic-enriched porphyritic basalts to an upper series of feldsparphyric basalts and basaltic andesites. They range across the medium- $\mathrm{K}_{2} \mathrm{O}$ to high- $\mathrm{K}_{2} \mathrm{O}$ fields and are differentiated to high- $\mathrm{K}_{2} \mathrm{O}$ calc-alkaline andesite.

\subsubsection{Central Chain}

Volcanism began in the central chain in latest Miocene time (Erromango island: 5.85.3 Ma; Bellon et al., 1984) and thus overlapped the eastern belt activity that ceased at about 3.5 Ma. Activity has been virtually continuous, at least from the earliest Pleistocene $(1.8 \mathrm{Ma})$. From Pleistocene to present times, volcanism, which was mainly subaerial, developed extensively along the length of the active arc. Lavas range from picrite to dacite or rhyodacite, with a peak frequency distribution in the basalt range, a trough between $52 \%$ and $62 \% \mathrm{SiO}_{2}$, and a smaller peak at $63 \% \mathrm{SiO}_{2}$. This distribution was considered to be representative of all the lavas in the exposed arc, but recent work seems to indicate that the compositional range of the central chain volcanics may be much more continuous (Robin et al., 1991, 1994; Eissen et al., 1992; Picard et al., 1995).

Two broad lava suites can be distinguished, although a compositional spectrum undoubtedly exists between the two. A higher- $\mathrm{K}_{2} \mathrm{O}$ suite is represented by picritic to rhyodacitic lavas on the islands of Tongoa, Ambrym, Aoba, and Santa Maria. These volcanics are strongly light-rare-earth-element (LREE) enriched and have ${ }^{87} \mathrm{Sr} /{ }^{86} \mathrm{Sr}$ ratios ranging from 0.7038 to 0.7043 (Briqueu and Lancelot, 1983). Lavas of the lower- $\mathrm{K}_{2} \mathrm{O}$ group dominate the islands of Matthew, Hunter (Maillet et al., 1986), Anatom, Tanna, Erromango, Efate, Lopevi, active submarine volcanoes around Epi, and all the Banks islands except Santa Maria. This lower- $\mathrm{K}_{2} \mathrm{O}$ suite characteristically exhibits LREEenriched REE patterns, but the degree of LREE enrichment is notably less than in the higher- $\mathrm{K}_{2} \mathrm{O}$ suite, and ${ }^{87} \mathrm{Sr} /{ }^{86} \mathrm{Sr}$ ratios are significantly lower $(0.7030-0.7033$; Briqueu and Lancelot, 1983). The lower- $\mathrm{K}_{2} \mathrm{O}$ suite might have been generated by higher degrees of partial melting at shallower levels in the upper mantle than the higher- $\mathrm{K}_{2} \mathrm{O}$ suite (Crawford et al., 1988), although the respective mantle sources were clearly different isotopically.

The structural consequences of the collision of the seismically inactive d'Entrecasteaux zone with the central part of the New Hebrides arc (Fig. 5.2) are now well documented (Collot et al., 1985, 1991, 1992a,b; Greene et al., 1988a,b, 1992). This collision, which began 4-3 Ma (Macfarlane et al., 1988), likely affects the central chain as well as the backarc area, tectonically and petrologically. This essential point, though still controversial (Roca, 1978; Monjaret, 1989), will be discussed later. 


\subsection{The North Fiji Basin}

Auzende et al. (Chapter 4 this volume) discuss the structure and evolution of the North Fiji basin (NFB) in detail, and the reader is referred to that chapter for a complete description. A summary of the geology and petrology of the NFB is presented here and is taken from Auzende et al. (1990), Huchon et al. (1994). Nohara et al. (1994), and Eissen et al. (1994).

The NFB is an active marginal basin bounded by the New Hebrides arc to the west, by the Hunter ridge and fracture zone to the south. by the Fiji Platform to the east. and by the Vitiaz paleosubduction zone to the north (Fig. 5.1). This basin was created by backarc spreading. which commenced behind the New Hebrides arc 10 to $8 \mathrm{Ma}$ ago in response to a clockwise rotation of the arc from an initial position close to the present location of the Vitiaz zone.

The formation of the NFB can be summarized as follows.

10 to $8 \mathrm{Ma}$ (or even in early Miocene time. according to Kroenke, 1984): Collision of the Ontong Java Plateau near the Solomon arc (volcanism ceased on New Hebrides western belt ca. 15-14 Ma) and reversal of the polarity of the subduction from southwestward along the Vitiaz zone to northeastward beneath the New Hebrides arc.

8 to $3 \mathrm{Ma}$ : Beginning of NFB opening, along an axis roughly parallel to the Vitiaz zone; clockwise rotation of the New Hebrides arc (the spreading axis trend rotates progressively from $\mathrm{N}_{2} 20^{\circ}$ to $\mathrm{N} 150^{\circ}$ ), and counterclockwise rotation of the Fiji Platform. Active volcanism occurs on the New Hebrides eastern belt until $3.5 \mathrm{Ma}$, and on the central chain from 5.8 to $5.3 \mathrm{Ma}$ onward.

3 to $0.7 \mathrm{Ma}$ : The spreading axis jumps into the central NFB from a $\mathrm{N} 150^{\circ}$ to a $\mathrm{N}-\mathrm{S}$ direction; synchronously, spreading starts in the Lau Basin. Active volcanism occurs on the New Hebrides central chain.

$0.7 \mathrm{Ma}$ to present: Modification of the spreading geometry in the central NFB between $15^{\circ} \mathrm{S}$ and $18^{\circ} 30^{\prime} \mathrm{S}$; migration of a triple junction (ridge-ridge-transform) near $16^{\circ} 40^{\prime} \mathrm{S}$. with a southern branch oriented $\mathrm{N} 15^{\circ}$, a northern branch oriented $\mathrm{N} 160^{\circ}$, and the prolongation of the North Fiji fracture zone, oriented $N 60^{\circ}$ in this area. Active volcanism continues on the New Hebrides central chain.

As demonstrated by Eissen $e t$ al. $(1991,1994)$, the dominant magma type produced in the NFB is N-MORB, showing depleted large-ion lithophile (LIL), high-field strength (HFS), and light rare-earth (LRE) element patterns. This magma type is the only one present along the most mature N-S spreading segment of the NFB (i.e., between $18^{\circ} 20^{\prime} \mathrm{S}$ and $21^{\circ} \mathrm{S}$ ).

Several ridges of various origin transect the NFB crust. In particular, the Hazel Holme-South Pandora Ridge is significant, since it may influence the volcano-tectonic evolution of the northern New Hebrides backarc area (Figs. 5.1 and 5.3). As indicated by Pelletier $e t$ al. (1993a), this seismically active ridge is considered to be an extensional zone in its western part (Hazel Holme extensional zone) and a slow spreading ridge in its easternmost part (South Pandora Ridge: Kroenke $e t$ al., 1994: Price and Kroenke, 1991). The western part of the Hazel Holme Ridge trends $\mathrm{N} 85^{\circ}-\mathrm{N} 90^{\circ} \mathrm{E}$ over $100-120 \mathrm{~km}$ in width. It is composed of a series of volcanic ridges, scarps, and parallel narrow troughs deeper than $3000 \mathrm{~m}$ (Fig. 5.4). To the west of $168^{\circ} 30^{\prime} \mathrm{E}$, the width of the whole structure decreases: lateral troughs disappear and a single $2500-3500 \mathrm{~m}$ deep E-W trough remains, bounded by symmetrical ridges culminating at a depth of $1700 \mathrm{~m}$ (Figs. 5.5, 5.6). This trough abruptly 


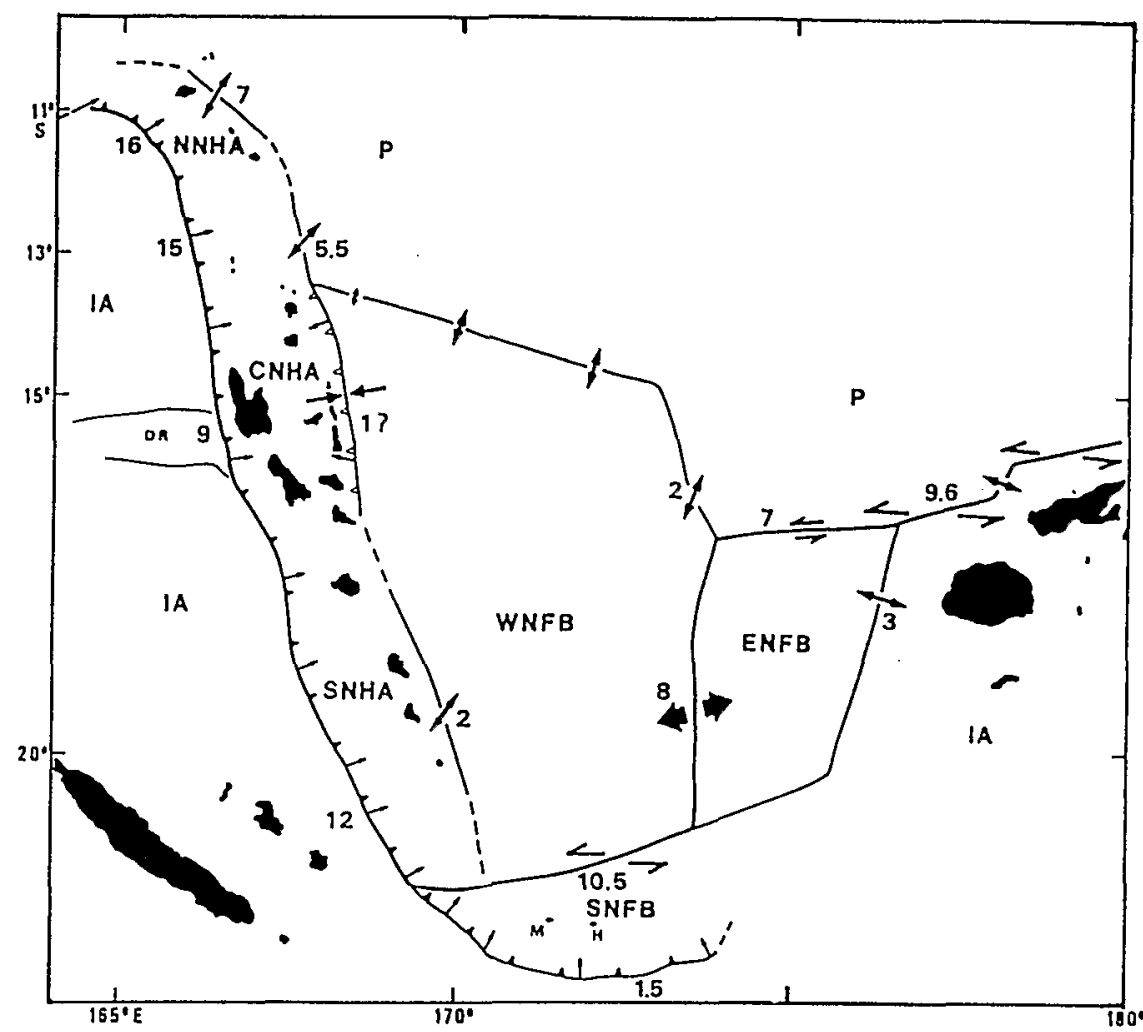

FIGURE 5.3. Present-day relative motions in the New Hebrides-North Fiji Basin region, as proposed by Louat and Pelletier (1989). P: Pacific plate; IA: Indo-Australian plate; DR: d'Entrecasteaux ridge; M and H: Matthew and Hunter volcanoes. WNFB, ENFB, and SNFB: western, eastern and southern North Fiji Basin microplates, respectively; NNHA, CNHA, and SNHA: northern, central and southern segments of the New Hebrides arc microplate, respectively. Numbers and arrows beside plate boundaries indicate the rates (in $\mathrm{cm} / \mathrm{yr}$ ) and trends of the relative motions. Very thick divergent arrows show the motion along the main spreading center of the North Fiji basin. Line with filled barbs corresponds to the New Hebrides Trench. Line with open barbs marks the New Hebrides backarc compressive belt.

terminates at $168^{\circ} 10^{\prime} \mathrm{E}$, at the very southernmost tip of the N-S-trending northern New Hebrides backarc area (Pelletier et al., 1993a).

\section{THE NEW HEBRIDES BACKARC TROUGHS}

\subsection{Previous Work and Recent Investigations}

A series of narrow and elongated troughs separates the New Hebrides island arc from the adjacent, active, marginal North Fiji Basin (Fig. 5.2). These troughs, however, do not extend along the entire length of the arc, since they are absent in the central backarc area (and, in particular, to the east of Maewo and Pentecost islands). Interestingly, this central area also lies opposite the d'Entrecasteaux zone. 


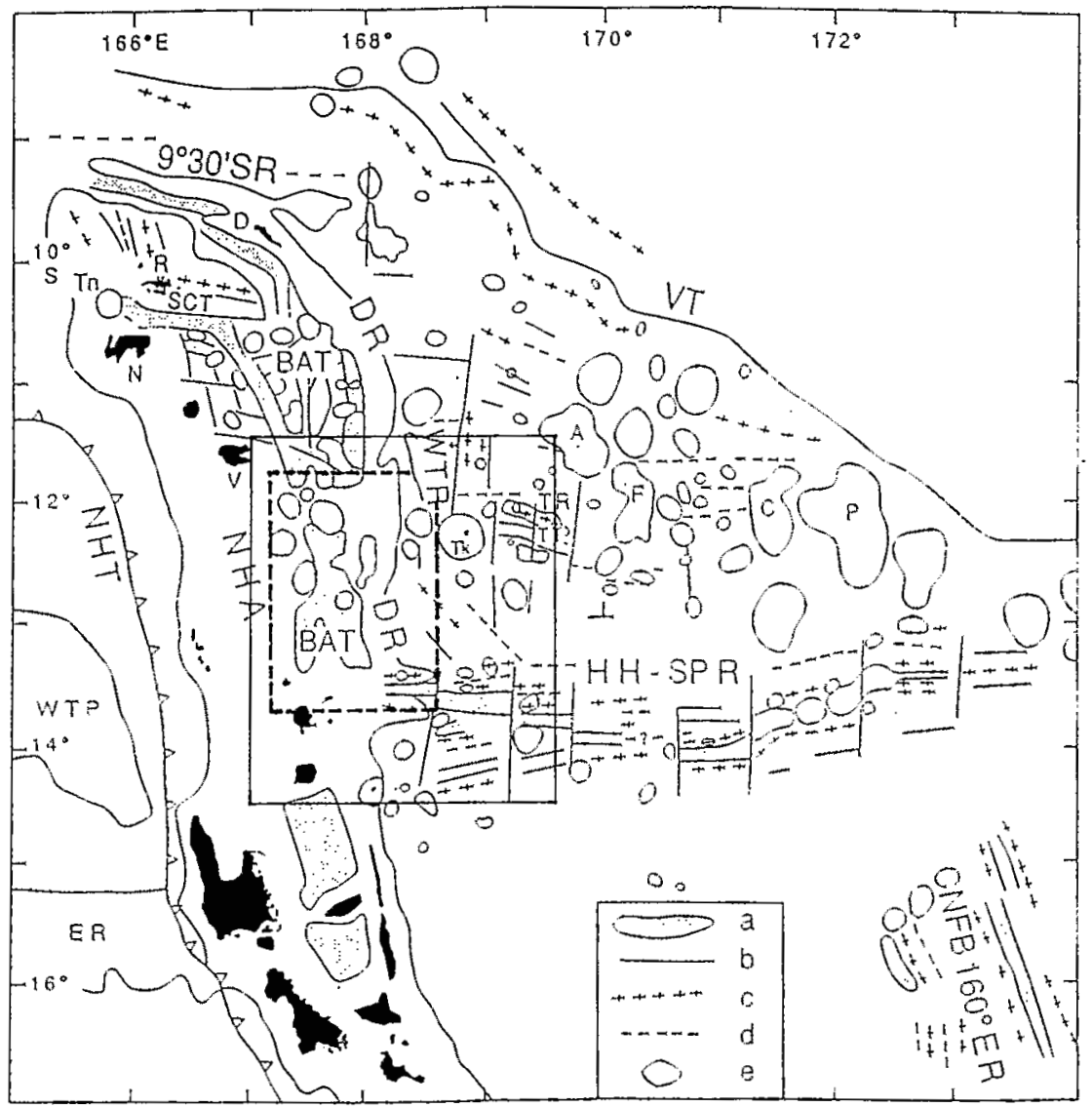

FIGURE 5.4. Structural map of the northern New Hebrides arc/northwestern North Fiji Basin (adapted from Pelletier et al. 1993a). (a) troughs and depressions; (b) structural trends and fractures; (c) structural highs: (d) structural lows; (e) volcanic highs. NHA: New Hebrides arc; VT: Vitiaz Trench: BAT: backare troughs domain (Jean-Charcot troughs): 9³0'SR: 9^30'S ridge: DR: Duff Ridge; WTR: West Tikopia ridge; TR: Tikopia Ridge; HH-SPR: Hazel Holme-south Pandora ridge; CNFB $160^{\circ}$ ER: central North Fiji Basin $160^{\circ} \mathrm{E}$ ridge: TT: Tikopia Trough: SCT: Santa Cruz Trough; WTP: west Torres plateau; ER: d'Entrecasteaux Ridge. Islands and reefs are in black; D: Duff Islands; R: Reef Islands; Tn: Tinakula Island; N: Nendo Island: V: Vanikoro Island; Tk: Tikopia Island; A: Anuta Island; F: Fatutaka island; C: Charlotte Bank: P: Pandora Bank. Areas detailed in Figs. 5.5-5.7 are outlined.

Thus, between $10^{\circ} \mathrm{S}$ and $21^{\circ} \mathrm{S}$, it is possible to distinguish three main areas in the New Hebrides backarc: (1) the Jean-Charcot troughs (JCT. named after the R/V Jean Charcot), or northern troughs, extend between $10^{\circ} \mathrm{S}$ (Pelletier $c t a l ., 1993 \mathrm{a}, \mathrm{b}$ ) and $13^{\circ} 30^{\prime} \mathrm{S}$. where they abut the western termination of the Hazel Holme Ridge (Fig. 5.4): a central area, extending from $13^{\circ} 30^{\prime} \mathrm{S}$ to $17^{\circ} 30^{\prime} \mathrm{S}$ - that is, roughly from the east of Vanua Lava Island to the east of Tongoa Island, is totally devoid of troughs (Fig. 5.2); (3) the Coriolis troughs (CT; named after the R/V Coriolis), or southern troughs, extend between $17^{\circ} 30^{\prime} \mathrm{S}$ and $21^{\circ} \mathrm{S}$, where their southern en echelon termination merges into the structural grain of the island arc (Monzier et al., 1991; Figs. 5.2, 5.9).

Since the first mention of the Coriolis troughs in the literature (Puech and Reichenfeld, 

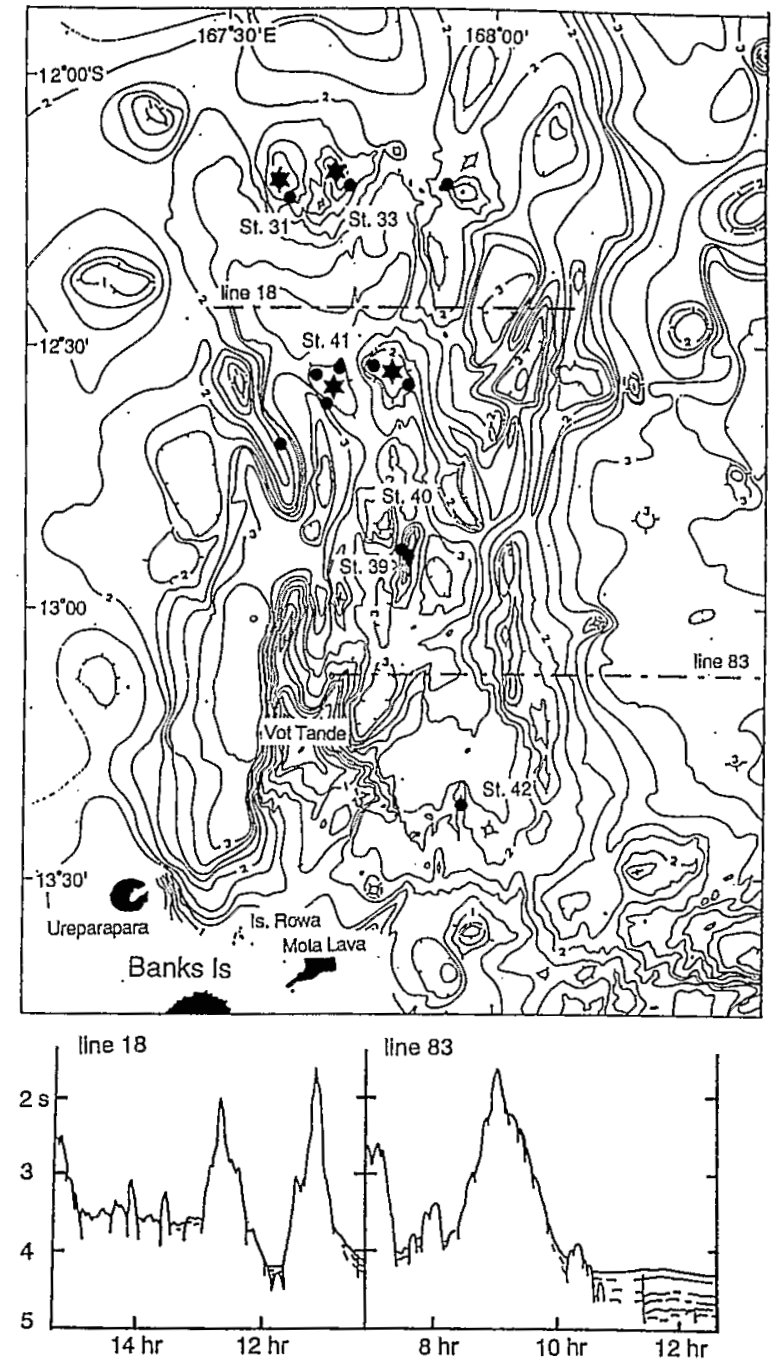

FIGURE 5.5. Bathymetric map of the Jean-Charcot troughs (after Charvis and Pelletier, 1989), showing positions of volcanic cones (stars) and sample localities (dots). Data from SEAPSO 2, KAIYO 89, and SAVANES cruises. Depths in $\mathrm{km}$, with $250 \mathrm{~m}$ isobaths. Bottom diagrams: seismic cross sections along survey lines shown above (adapted from Nakada et al., 1994). See Fig. 5.4 for location.

1969), several oceanographic cruises have been partly or fully devoted to the study of the New Hebrides backarc area (Dubois et al., 1978). The most recent, which provide most of the data used in this chapter, include SEAPSO 2 (Nov. 1985, R/V Jean Charcot; Récy et al., 1986); EVA 13 (1986, R/V Coriolis; Sage and Charvis, 1991); MULTIPSO (May 1987, R/V Jean Charcot; Daniel et al., 1989); EVA 14 (Aug. 1987, R/V Le Noroît; Pelletier et al., 1988); GLORIA survey (Aug. 1989, HMAS Cook; Johnson et al., 1993; Price et al., 1993; Tiffin, 1993); KAIYO 89 (Dec. 1989-Jan. 1990, R/V Kaiyo; KAIYO 89 Cruise Report, 1990; Nakada et al., 1994; this chapter); YOKOSUKA 90 (Jan.-Feb. 1991; R/V Yokosuka; 


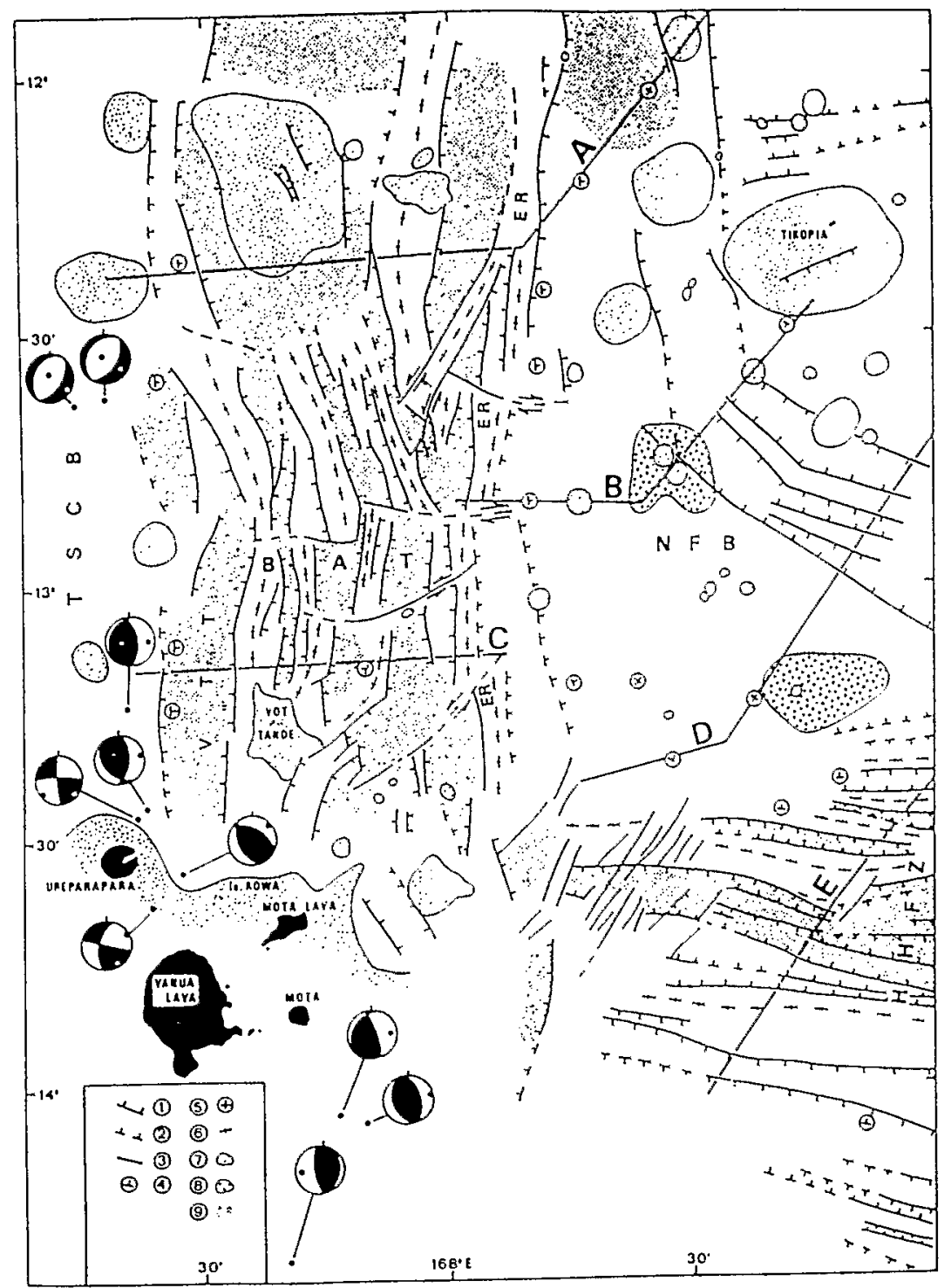

FIGURE 5.6. Structural map of the Jean-Charcot troughs (from Charvis and Pelletier. 1989). 1: normal fault; 2 : small and/or inferred normal fault; 3: transverse tectonic lineation (arrows indicate strike-slip fault); 4: inclined bedding: 5: horizontal bedding: 6 : structural high: 7: volcano; 8 : lava flow; 9 : major graben. TSCB: Torres-Santa Cruz sedimentary basin: BAT: backarc troughs (Jean-Charcot troughs): VTT: Vot Tande Trough; ER: Eastern Ridge (Duff Ridge of Fig. 5.4); HHFZ: Hazel Holme fracture zone; NFB: North Fiji Basin. See Fig. 5.4 for location. 
Eissen et al., unpublished information, 1994); SANTA CRUZ (Nov.-Dec. 1991; R/V Le Noroît; Pelletier et al., 1993b); SAVANES (Dec. 1991-Jan. 1992; R/V Le Norô̂t and Cyana submersible; Savanes 91-92 Cruise Report, 1992; Nakada et al., 1994; this chapter).

The KAIYO 89, YOKOSUKA 90, and SAVANES cruises were parts of the STARMER French-Japanese Joint Project (Joint Research Program on Rift System in the Pacific Ocean; Auzende and Urabe, 1994), endorsed by SOPAC (the South Pacific Applied Geoscience Commission, Suva, Fiji).

\subsection{Structure and Tectonics}

\subsubsection{The Jean-Charcot Troughs}

The Jean-Charcot troughs (JCT) are a succession of discontinuous and, in some areas, anastomosing, horsts, grabens, and half-grabens, trending slightly oblique to the submeridional northern New Hebrides central chain (Fig. 5.4). Between $12^{\circ} 20^{\prime} \mathrm{S}$ and $13^{\circ} 20^{\prime} \mathrm{S}$, in an area 50-55 km wide (E-W) and 100-120 km long (N-S), at least six individual troughs have been recognized, each 3-9 km wide and 20-35 km long (Figs. 5.5, 5.6; Récy et al., 1986, 1990; Matsumoto et al., 1992; Johnson et al., 1993). The JCT are limited to the west by the submarine extensions of the New Hebrides central chain; to the south by the Hazel Holme ridge; and to the east by the N-S Duff ridge, culminating around $1250 \mathrm{~m}$ depth, which separates the JCT from the North Fiji Basin. The northern extension of the JCT, however, is still conjectural. North of a shallow (up to $460 \mathrm{~m}$ deep) volcanic complex centered near $12^{\circ} 10^{\prime} \mathrm{S}$, the JCT domain widens up to $100 \mathrm{~km}$ and abuts the intra-arc E-W-trending Santa Cruz Trough (Fig. 5.4; Pelletier et al., 1993a).

The average depth of the JCT is $3000-3500 \mathrm{~m}$ (Fig. 5.5), similar to the mean depth of the North Fiji Basin (Pelletier et al., 1993a; the maximum depth in the whole New Hebrides backarc, $3658 \mathrm{~m}$, was recorded in the JCT, during the KAIYO 89 cruise, at $\left.12^{\circ} 46.9^{\prime} \mathrm{S}-167^{\circ} 41.9^{\prime} \mathrm{E}\right)$.

Seismic reflection profiles across the JCT show thick sedimentary layers (more than 1-s twt), which are usually tilted eastward and dip more steeply downsection. Unconformities or tectonic discordances are frequent. The most recent deposits also dip more steeply downsection, indicating coeval tectonics and sedimentation during the entire structural history of the troughs (Charvis and Pelletier, 1989; Récy et al., 1990).

During the period $1977-1987$ no shallow earthquake $(0-70 \mathrm{~km})$ with magnitude large enough to have a focal mechanism determination has been recorded in the entire JCT area or in the western end of the Hazel Holme Ridge (Charvis and Pelletier, 1989). Yet Louat and Pelletier (1989) suggested a surprisingly high rate of extension in the JCT $\left(5.5 \mathrm{~cm} / \mathrm{yr}\right.$ along a $\mathrm{N} 45^{\circ} \mathrm{E}$ direction, at $13^{\circ} \mathrm{S} ; 7 \mathrm{~cm} / \mathrm{yr}$ along a $\mathrm{N} 37^{\circ} \mathrm{E}$ direction at $11^{\circ} \mathrm{S} ; \mathrm{Fig}$. 5.3), using the RM-2 plate model of Minster and Jordan (1978) combined with a large set of regional data (i.e., shallow seismicity, focal mechanism solutions, and magnetism). Louat and Pelletier (1989) argue that horst-and-graben structures like the JCT can be formed in an aseismic but tectonically active environment. However, GLORIA imagery data show no evidence of any neovolcanism in these troughs (Figs. 5.7, 5.8). The eroded nature of at least some of the seamounts behind the arc, as well as the thick sediment fills in the grabens of the Hazel Holme Ridge, led Johnson et al. (1993) to suggest that these structures are not young. However, this interpretation is at odds with the evidence cited for recent faulting producing rotated sedimentary sequences. 


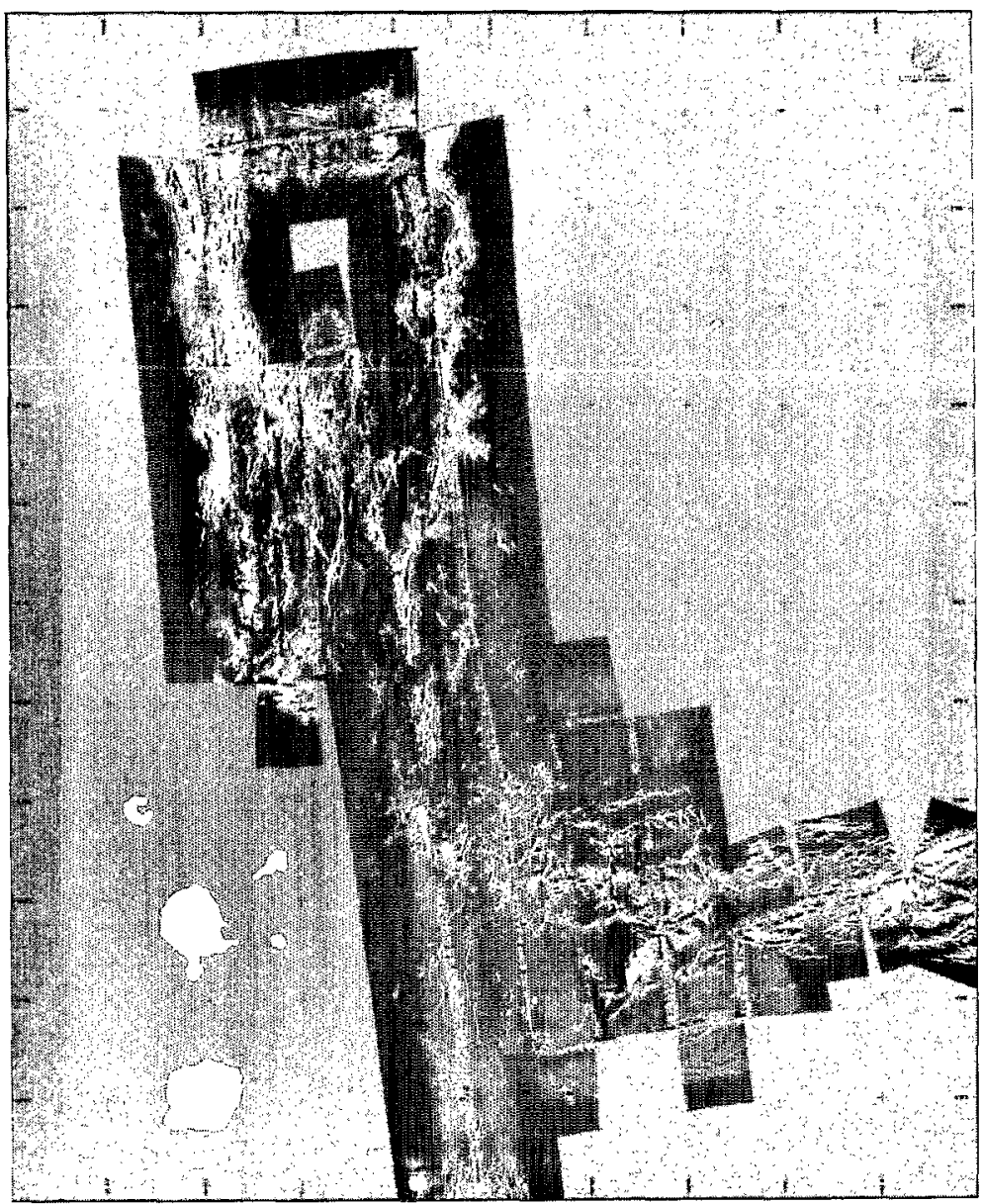

FIGURE 5.7. GLORIA imagery of northern New Hebrides-southeastern Solomon Islands area (from Johnson et $u l$, , 1993). Lineations indicated by strong white reflections are associated with the Hazel Holme Ridge in lower right and the Jean-Charcot troughs in upper diagram. See Fig. 5.4 for location.

\subsubsection{The Coriolis Troughs}

The morphology of the CT looks comparatively simpler (Fig. 5.9). They are made up of well-delineated grabens (Daniel, 1982) discontinuously paralleling the eastern flank of the southern New Hebrides central chain between Efate and Anatom Islands. SeaBeam bathymetry (Récy et al. 1986. 1990) and GLORIA seafloor imagery (Price et al., 1993) allow three main grabens to be distinguished in the CT. namely the Efate, Erromango, and Futuna troughs.

The Efate Trough is a complex double graben, trending NNW-SSE, 10-25 km wide and about $100 \mathrm{~km}$ long. A horst at a depth of $1200 \mathrm{~m}$ separates a western, small, asymmetrical graben (mean depth: $2150 \mathrm{~m}$ ) from a larger, deeper, eastern graben (mean depth: 2500 $2600 \mathrm{~m}$ ). The latter is bounded eastward by a very steep normal fault and terminates southward on a structural threshold about $1500 \mathrm{~m}$ deep, occupied to the west at $18^{\circ} 32^{\prime} \mathrm{S}-$ $169^{\circ} 35^{\prime} \mathrm{E}$ by a $1000 \mathrm{~m}$ high. less than $500 \mathrm{~m}$ deep volcanic seamount (Monzier et al. 1984a: 


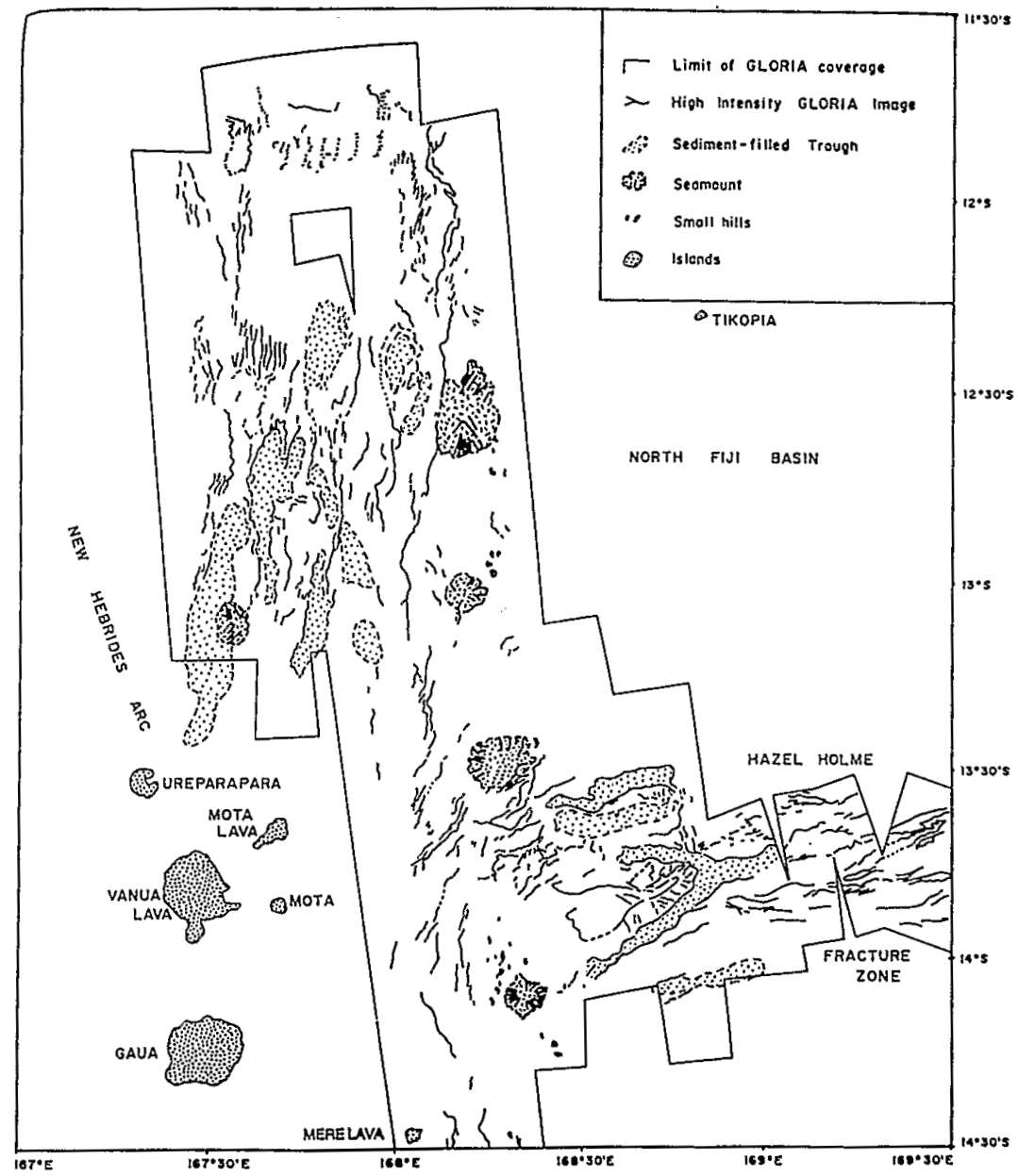

FIGURE 5.8. Geological interpretation of the GLORIA imagery of Fig. 5.7 (from Johnson et al., 1993).

Récy et al., 1990). Downfaulted sediment-draped blocks can be identified in seismic profiles across the Efate Trough, but substantial areas appear on GLORIA imagery to be unsedimented basement outcrop (Fig. 5.10).

Southeastward, the Efate Trough is succeeded by another depression, the Erromango Trough, which is about $75 \mathrm{~km}$ long, $30 \mathrm{~km}$ wide, and 2500-3100 m deep. Its northeastern and southwestern margins, interpreted as fault scarps, are roughly linear and parallel and rise to about $1500 \mathrm{~m}$ depth. An unsampled bathymetric high $(2100 \mathrm{~m}$ bsl $)$ in the center of the trough $\left(19^{\circ} 05^{\prime} \mathrm{S}-169^{\circ} 52^{\prime} \mathrm{E}\right)$ is highly reflective on GLORIA imagery and may correspond to a young, unsedimented volcanic feature (Price et al., 1993).

There is no major structural discontinuity between the Erromango Trough and the Futuna Trough, and the latter can be considered as the southeastward extension of the former (Daniel 1982; Monzier et al. 1984a). The Futuna Trough is approximately $75 \mathrm{~km}$ long, $20-30 \mathrm{~km}$ wide, and $3200 \mathrm{~m}$ deep. It is therefore the deepest graben of the CT (the maximum depth recorded during SEAPSO 2 cruise is about $3400 \mathrm{~m}$, at $19^{\circ} 42.5^{\prime} \mathrm{S}-$ $170^{\circ} 09^{\prime} \mathrm{E}$, about $20 \mathrm{~km}$ south-southwest of Futuna Island). Its asymmetrical morphology is 

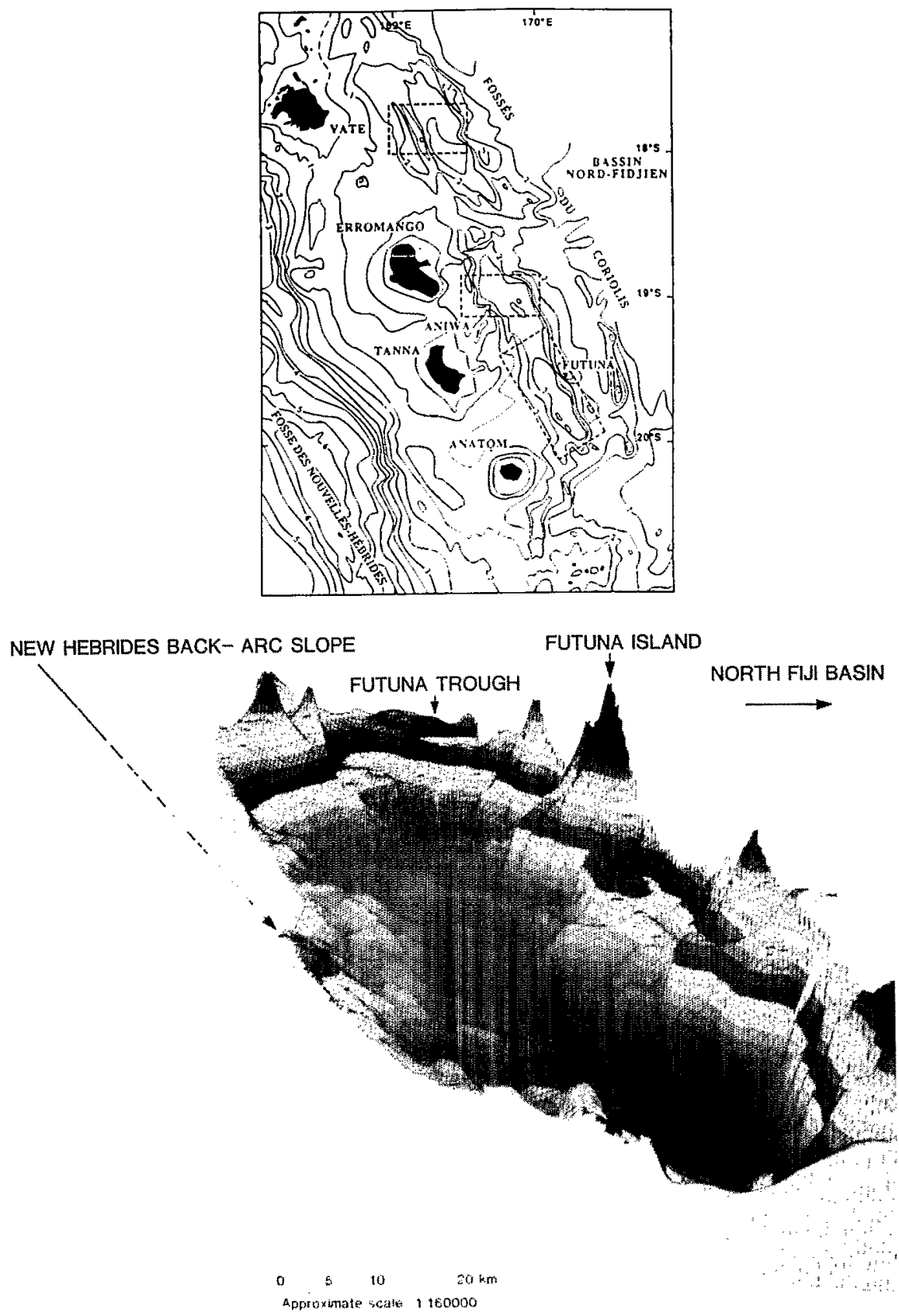

FIGURE 5.9. The Coriolis troughs (from Récy et al, 1990). (Top) Bathymetric map. Depths in km, with 500-m isobaths (from Monzier et al.. 1984a). SeaBeam surveyed outlined areas. See Fig. 5.2 for location (Note: Vate $=$ Efate). (Bottom) The Futuna Trough. Block diagram hased on SeaBeam bathymetry. Vertical exaggeration: 5/1; mesh size: $300 \mathrm{~m}$; each nuance represents a $150 \mathrm{~m}$ depth unit. 
obvious, with the eastern wall steeper and shallower (above sea level at Futuna Island) than the western wall (Fig. 5.9). Rough topography, steep fault scarps trending NW-SE, and a thin (less than $80 \mathrm{~m}$ ) sediment cover characterize most of its floor.

The shallower depth of the Efate Trough may indicate thermal uplift, consistent with extensive recent volcanism apparent on GLORIA imagery (Fig. 5.10). The deeper Erromango and Futuna troughs seem to be relatively immature backarc structures, formed as a consequence of lithospheric extension accompanying uplift or doming (Price et al., 1993). Numerous shallow earthquakes border the western limit of the CT between $18^{\circ} 50^{\prime} \mathrm{S}$

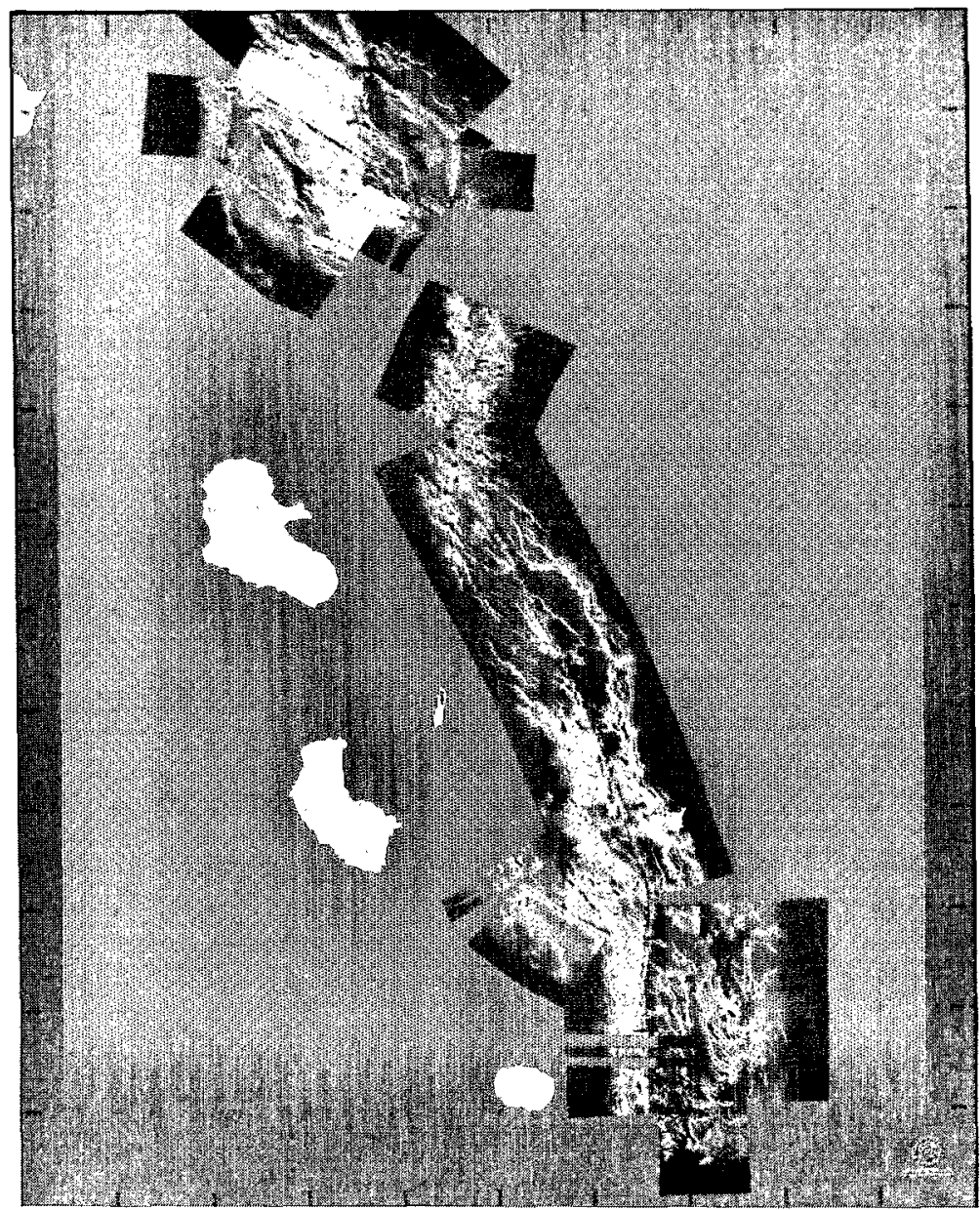

FIGURE 5.10. GLORIA imagery of the Coriolis troughs (from Price et al., 1993). See Fig. 5.2 for location. South of $19^{\circ} 15^{\prime} \mathrm{S}$, the line $\mathrm{R}$ to $\mathrm{W}$ marks the northern wall of the northern Futuna trough. $\mathrm{P}$ is an isolated, sediment-filled basin, perched above the Futuna Trough. South of $19^{\circ} 45^{\prime} \mathrm{S}$, dark area labeled $S$ is an acoustic shadow on the eastern wall of the southern Futuna Trough. $R$ indicates a series of scarps marking the southwestern wall of the trough. Note: Vate $=$ Efate; Anetium $=$ Anatom. 
and $21^{\circ} \mathrm{S}$, and normal faulting mechanisms indicate a NE-SW extension. Louat and Pelletier (1989) calculated a rate of $2 \mathrm{~cm} / \mathrm{yr}$ along a $\mathrm{N} 37^{\circ} \mathrm{E}$ direction, at $20^{\circ} \mathrm{S}$ (Fig. 5.3).

Gravity data show a clear positive anomaly paralleling both western and eastern borders of the CT, without any deep-rooted compensation (Collot and Malahoff, 1982), indicative of rift-flank flexural uplift (Weissel and Karner, 1989).

The formation of intra-arc sedimentary basins may have partly influenced the evolution of the New Hebrides backarc area. Among them, the Aoba and Vanikoro-Torres basins deserve special mention.

\subsubsection{The Aoba Basins}

The central part of the New Hebrides island arc, between Banks Islands and Epi Island, is structurally complex and has recorded the effects of the ongoing collision of the arc with the d'Entrecasteaux zone (Fig. 5.11; Collot et al, 1985, 1992a; Collot and Fisher, 1988; Greene and Johnson, 1988). Deep and thick intra-arc sedimentary basins (North and South Aoba basins) separate the old western belt islands (Espiritu Santo, Malakula) from the younger eastern belt islands (Maewo, Pentecost). Preliminary results of Ocean Drilling Program (ODP) Leg 134 in the North Aoba Basin (Fig. 5.11) indicate that this basin is the product of island-arc volcanism and tectonic deformation-that is, a piggyback subsiding basin pinched and overthrust between two ancient volcanic arcs (Gérard, 1993). At Site 832 , an unconformity marks the uplift time of the central part of the western belt in response to the collision of the d'Entrecasteaux zone. The age of this sedimentary hiatus is near the Upper Pliocene-Lower Pleistocene boundary. Recent (Pleistocene) basin-filling recorded at Sites 832 and 833 comes from effusive products of the central chain volcanoes (Aoba. Santa Maria-Gaua, and Mere Lava islands). At Site 833, Pleistocene basaltic sills intruded the Lower Pliocene sedimentary sequence. This recent sill complex indicates that volcanism was active along the eastern belt during the early Pliocene as well as during the Pleistocene (Collot et al., 1992a).

Compression (North Aoba Basin; Greene and Johnson, 1988; Daniel et al.. 1989). distension (South Aoba Basin; Greene and Johnson, 1988), and folds and faults with different orientations characterize the Aoba basins area. Moreover, compressive stresses are relayed to the very eastern margins of Maewo and Pentecost, since westward-dipping thrust faults appear on seismic reflection records (Louat and Pelletier, 1989; Récy et al.. 1990). Shallow earthquake focal mechanisms confirm this observation (Louat and Pelletier. 1989).

On GLORIA seafloor imagery (Fig. 5.12), the structural limit between the central New Hebrides arc platform and the North Fiji Basin clearly appears as anastomosing fault scarps, between the midpoint of Pentecost Island and the northern end of Maewo Island (Price et al., 1993: Tiffin, 1993).

\subsubsection{The Vanikoro-Torres Basin}

The poorly known Vanikoro-Torres basin, which extends between Vanikoro and Vanua Lava islands, east of Torres Islands (Fig. 5.13), is a very thick sedimentary basin (up to $6 \mathrm{~km}$ thick in its center: Holmes, 1988) lying on the summit platform of the northern New Hebrides arc (Falvey and Greene, 1988). On seismic reflection profiles, three unconformities are distinguished (early-middle Miocene; late Miocene; late Pliocene-early Pleistocene), as well as faulting and folding extending up to the surface (Falvey and 

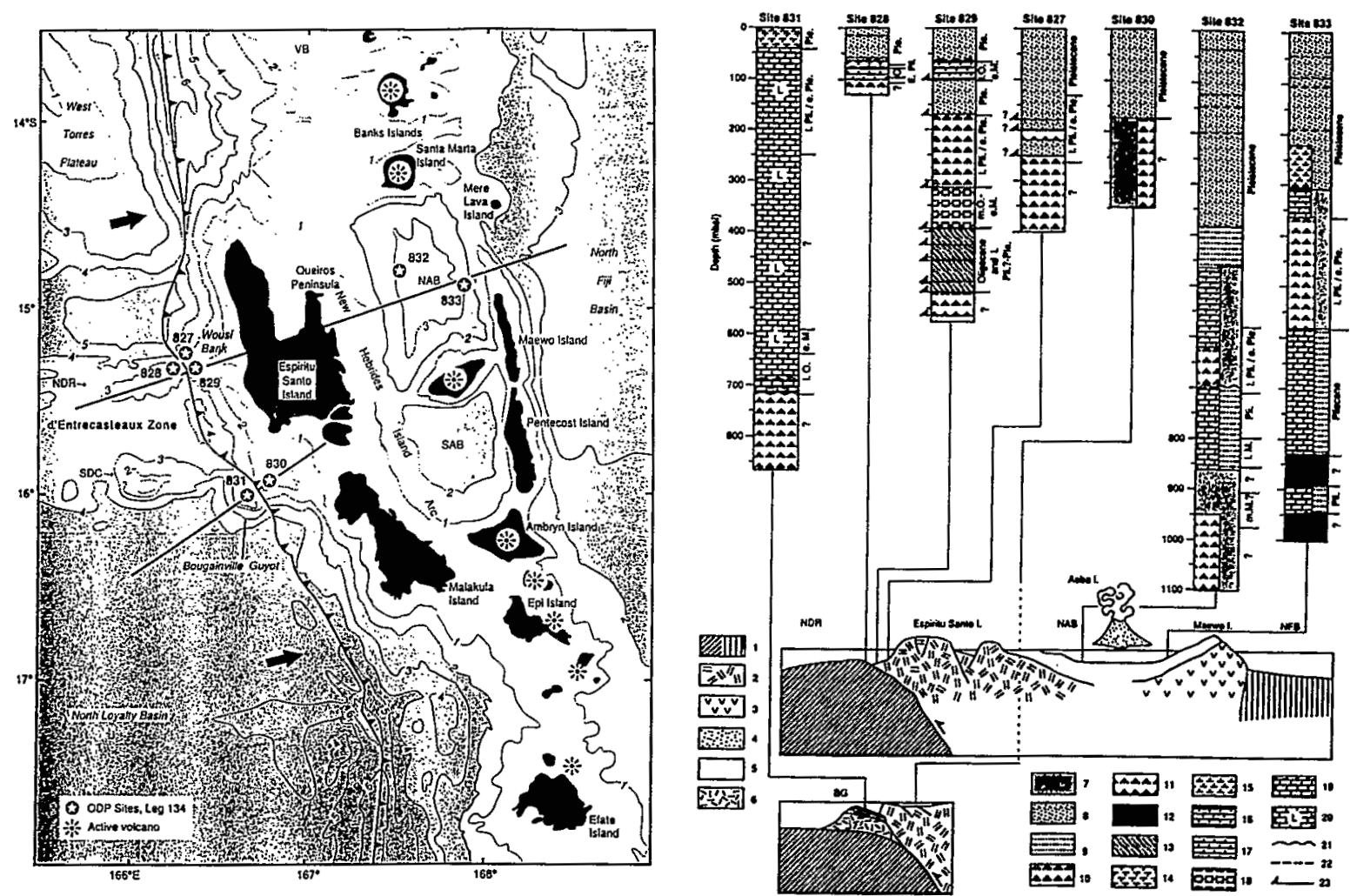

FIGURE 5.11. (Left) Location of sites drilled during ODP Leg 134. Bold lines indicate location of cross sections shown at right. NDR: North d'Entrecasteaux Ridge; SDC: south d'Entrecasteaux chain; NAB: North Aoba Basin; SAB: South Aoba Basin; VB: Vanikoro Basin. Bold line with teeth indicates approximate position of subduction zone; teeth are on upper plate. Arrows indicate direction of plate convergence. Bathymetry in $\mathrm{km}$. (Right) Geologic columns and cross sections, ODP Leg 134. 1: oceanic crust; 2: western belt volcanic rocks; 3: eastern belt voicanic rocks; 4: central chain volcanic rocks; 5: basin fill; 6: guyot volcanic rocks; 7: volcanic sand/sandstone; 8: volcanic silt/siltstone; 9: volcanic sandstone/siltstone/claystone; 10: sed-lithic breccia; 11: volcanic breccia; 12: basalt chalk; 13: multiple slivers of siltstone and chalk; 14: foraminiferal ooze; 15: nanofossil ooze; 16: foraminiferal chalk; 17: nannofossil chalk; 18: calcareous chalk; 19: pelagic limestone; 20: lagoonal limestone; 21: unconformity; 22: ash; 23: thrust fault. NDR: north d'Entrecasteaux Ridge; BG: Bougainville guyot; NAB: North Aoba Basin; NFB: North Fiji Basin (From Collot et al., 1992a). 


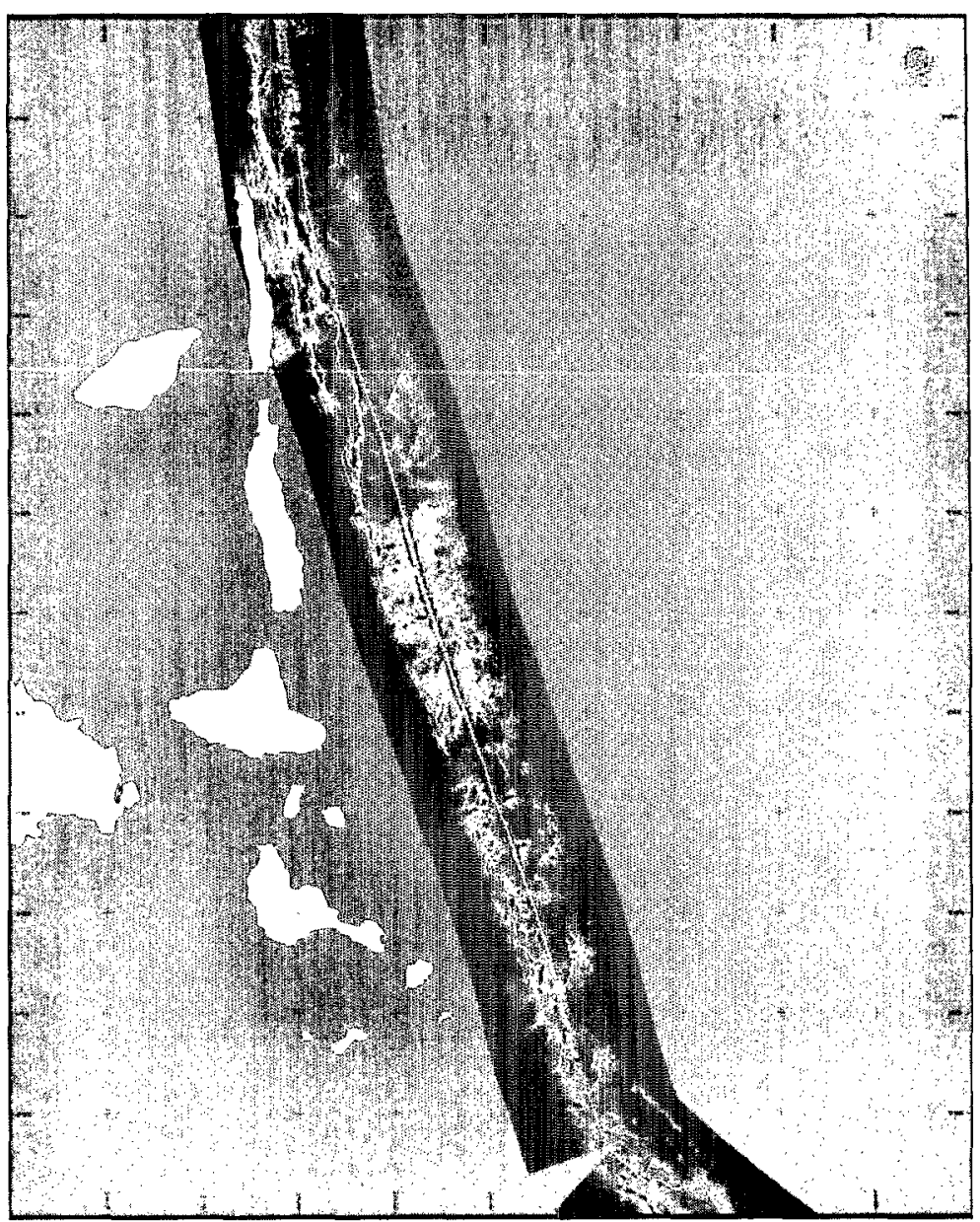

FIGURE 5.12. GLORIA imagery along the New Hebrides backarc between $14^{\circ} 30^{\prime} \mathrm{S}$ and $17^{\circ} 30^{\prime} \mathrm{S}$ (from Price et al., 1993). See Fig. 5.2 for location.

Greene, 1988). The easternmost part of the Vanikoro-Torres Basin (i.e., the area closest to the northern NHBAT) is intruded by young (Pleistocene-Holocene) volcanic intrusions from the New Hebrides central chain.

\subsection{Volcanic Petrology, Geochronology, and Geochemistry}

\subsubsection{Volcanic Petrology}

Before the SEAPSO 2 cruise (1985), the petrological knowledge of the NHBAT was limited to two studies. Dugas et al. (1977) described and analyzed a few volcanic samples from the Futuna Trough (GEORSTOM IIl CENTRE cruise, 1975), while Vallot (1984) presented the first compilation of dredged samples from along the whole southern New Hebrides arc (i.e., inner trench slope, arc substratum, and Coriolis backarc troughs) during GEORSTOM III CENTRE and EVA V (1977) cruises. 
FIGURE 5.13. The central and northern New Hebrides arc, with its intra-arc sedimentary basins (North Aoba, South Aoba and Vanikoro-Torres basins) and fault systems. The Vanikoro-Torres basin appears as Torres-Santa Cruz sedimentary basin in Fig. 5.6, and as Vanikoro Basin in Fig. 5.11. The Jean-Charcot troughs area is outlined (see Fig. 5.5). Vanikolo = Vanikoro. Bathymetry in km. Islands toponymy: VA: Vanikoro; VL: Vanua Lava; VT: Vot Tande; MT: Mota Lava; TK: Tikopia; MO: Maewo; PT: Pentecost; AO: Aoba; ES: Espiritu Santo; MA: Malakula; AM: Ambrym (From Falvey and Greene, 1988).

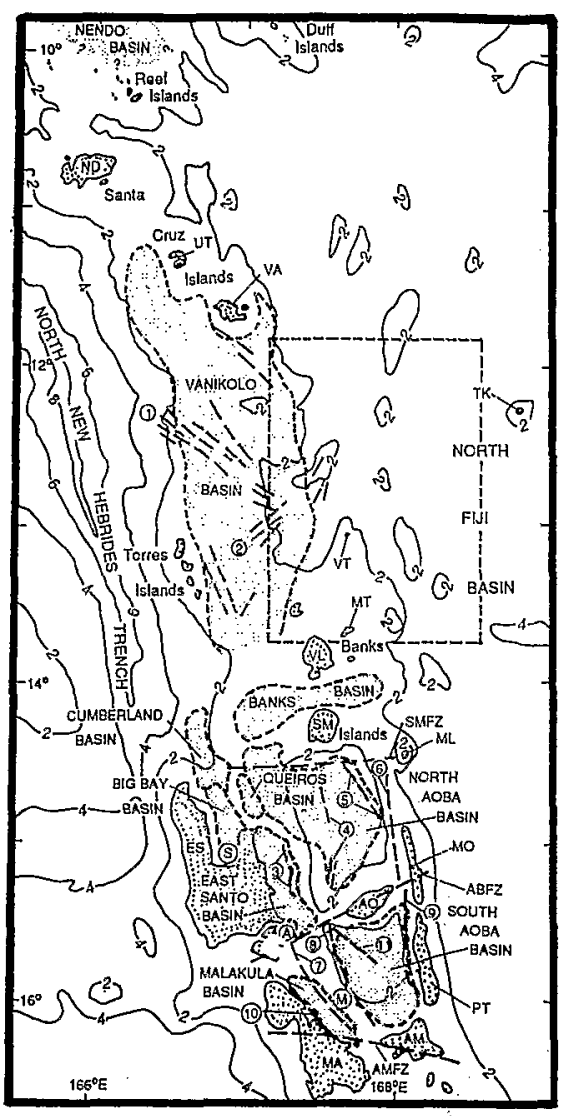

In order to get a closer view of the structure and volcanology of these troughs, a comprehensive geological, geophysical, and geochronological study was initiated during the 1985 SEAPSO 2 cruise (Récy et al., 1986; Monjaret et al., 1991). Most of the petrological data discussed here come from this study. A few cruises with more specific targets followed more recently (see above), and some data from these are also included in this chapter (Table I).

The dredged samples and samples picked up in situ (via submersible) from the NHBAT have been classified geographically from north to south according to neighboring islands or structures as follows: Vanikoro (VAN), Tikopia (TIK), and Vot Tande (VOT), for the Jean-Charcot troughs (JCT); Hazel Holme (HAZ); Efate (EFA), Erromango (ERR), Futuna (FUT), and Anatom (ANA) for the Coriolis troughs (CT). The coordinates of these samples and their structural settings are shown in Table Ia-Ib and Figs. 5.5, 5.14, and 5.15. As summarized by Monjaret et al. (1991), basalts (45-53\% $\mathrm{SiO}_{2}$ ) clearly predominate (60\% of lavas dredged during the SEAPSO 2 cruise), whereas basaltic andesites (53-60\%) and dacites $\left(\mathrm{SiO}_{2}>60 \%\right)$ represent $13 \%$ and $27 \%$ of dredged samples, respectively. These relative abundances did not drastically change after sampling carried out during KAIYO 89, YOKOSUKA 90 and SAVANES cruises (Table II).

Lavas from the JCT are usually aphyric or weakly porphyritic and show high vesicularity (generally $20 \%$ of the rock volume, sometimes up to $40-50 \%$ ). By contrast, 
volcanics from the CT are generally porphyritic (15\% of phenocrysts: plagioclase, clinopyroxene \pm olivine, orthopyroxene, Fe-Ti oxides) or. in some cases, highly porphyritic (up to $50 \%$ phenocrysts).

Nine petrological types (Table II: types a to i) can be distinguished in the NHBAT volcanics (Monjaret et al., 1991). Mafic lavas are represented by six types:

- Type a: MORB (Mid ncean ridge basalts)

- Types b, c. d: IAT (island-arc tholeiites), which may be enriched in $\mathrm{TiO}_{2}$ (type c), in $\mathrm{MgO}$ (type d), or in $\mathrm{TiO}_{2}$ and $\mathrm{MgO}$ (type c+d)

- Type e: $\mathrm{CAB}$ (calc-alkaline basalts and andesites), which are also in some cases enriched in $\mathrm{TiO}_{2}$ (type e $+c$ ) or in $\mathrm{MgO}$ (type e+d)

- Type f: BABB (backarc basin basalts)-basalts with a composition intermediate between MORB and IAT

Felsic lavas are represented by three types:

- Type g: high-Na/low-K dacites (Nakada et al., 1994)

- Type h: high-K dacites

- Type $\mathrm{i}$ : hyper- $\mathrm{K}$ dacites

MORB (a), BABB (f), and high-Na/low-K dacites ( $g$ ) have only been found in the northern troughs (JCT) and in the Hazel Holme area: MORB (a) are restricted to VAN and $\mathrm{HAZ}$ areas, BABB (f) to the VAN area. high-Na/low-K dacites (g) to the VAN and TIK areas (Table II); all other petrological types recovered in the NHBAT resemble the ones found on the central chain islands.

\subsubsection{Geochronology}

Most K-Ar ages presented in Table III originated from SEAPSO 2 cruise samples and were obtained in France (UBO. Université de Bretagne Occidentale, Brest). They have been discussed elsewhere (Monjaret et al., 1987, 1991: Monjaret, 1989; Récy et al., 1990). Complementary data from samples 3152 (Vanikoro area), 3981X and $415 \mathrm{X}$ (Tikopia area), recovered during the KAIYO 89 cruise, were analyzed in Japan and have been added to this list.

Sample 7M2 is a MORB dredged on the Duff Ridge (Table I; Fig. 5.14) (i.e., on the eastern border of the Vanikoro area). It gave a K/Ar age of $12.4 \pm 0.9 \mathrm{Ma}$ (Table III). This MORB sample represents the oldest known remnant of the North Fiji Basin oceanic crust (Monjaret et al., 1991) and is not considered to be related to oceanic spreading in the NHBAT. K-Ar ages of BABB dredged in the northern JCT (type $f$ in Table III) range between 3.9 and $1.1 \mathrm{Ma}$. Other geochemical types encountered in the NHBAT are characterized by a rather large spectrum of isotopic ages, most of them, however, being younger than 4 Ma. To Monjaret et al. (1991) this succession reveals a polyphased and diachronous trough formation.

\subsubsection{Geochemistry}

3.3.3.1. Major Elements. As noted by Fryer et al. (1990) for the volcanics from the Izu-Bonin backarc rifts, the wide range of $\mathrm{SiO}_{2}$ contents together with the high- $\mathrm{Al}_{2} \mathrm{O}_{3}$ contents of the NHBAT volcanics (Table II; Fig. 5.16) clearly emphasize their arc/backarc environment, and this is confirmed by their $\mathrm{TiO}_{2}$ contents. which are usually lower than $1.2 \%$. However, the $\mathrm{SiO}_{2}$ contents of the NHBAT volcanics cover a compositional continuum. which is not common in such a backarc environment. 


\section{TABLE I}

Location (a) and Structural Setting (b) of Volcanic Samples ${ }^{a}$

\begin{tabular}{llll}
\hline Location & Start & End & Depth (m) \\
\hline
\end{tabular}

(a)

Jean Charcot Troughs

Vanikoro area (VAN)

$\begin{array}{ll}1 & 12^{\circ} 12.9^{\prime} \mathrm{S}-167^{\circ} 34.6^{\prime} \mathrm{E} \\ 2 & 12^{\circ} 15.3^{\prime} \mathrm{S}-167^{\circ} 38.5^{\prime} \mathrm{E} \\ 3 & 12^{\circ} 13.5^{\prime} \mathrm{S}-167^{\circ} 40.6^{\prime} \mathrm{E} \\ 5 & 12^{\circ} 09.1^{\prime} \mathrm{S}-167^{\circ} 48.5^{\prime} \mathrm{E} \\ 6 & 12^{\circ} 14.7^{\prime} \mathrm{S}-167^{\circ} 50.3^{\prime} \mathrm{E} \\ 7 & 12^{\circ} 16.3^{\prime} \mathrm{S}-167^{\circ} 51.8^{\prime} \mathrm{E} \\ 3321 & 12^{\circ} 10.3^{\prime} \mathrm{S}-167^{\circ} 47.0^{\prime} \mathrm{E} \\ 3151 & 12^{\circ} 11.6^{\prime} \mathrm{S}-167^{\circ} 34.9^{\prime} \mathrm{E} \\ 3154 & 12^{\circ} 11.6^{\prime} \mathrm{S}-167^{\circ} 349^{\prime} \mathrm{E} \\ 3152 & 12^{\circ} 11.6^{\prime} \mathrm{S}-167^{\circ} 34.9^{\prime} \mathrm{E} \\ 3155 & 12^{\circ} 11.6^{\prime} \mathrm{S}-167^{\circ} 34.9^{\prime} \mathrm{E}\end{array}$

Tikopia area (TIK)

$\begin{array}{ll}3981 & 12^{\circ} 51.5^{\prime} \mathrm{S}-167^{\circ} 50.5^{\prime} \mathrm{E} \\ 3981 \mathrm{X} & 12^{\circ} 51.5^{\prime} \mathrm{S}-167^{\circ} 50.5^{\prime} \mathrm{E} \\ 3982 & 12^{\circ} 51.5^{\prime} \mathrm{S}-167^{\circ} 50.5^{\prime} \mathrm{E} \\ 3983 & 12^{\circ} 51.5^{\prime} \mathrm{S}-167^{\circ} 50.5^{\prime} \mathrm{E} \\ 4150 & 12^{\circ} 33.3^{\prime} \mathrm{S}-167^{\circ} 40.6^{\prime} \mathrm{E} \\ 4151 & 12^{\circ} 33.3^{\prime} \mathrm{S}-167^{\circ} 40.6^{\prime} \mathrm{E} \\ 4153 & 12^{\circ} 33.3^{\prime} \mathrm{S}-167^{\circ} 40.6^{\prime} \mathrm{E} \\ 4155 & 12^{\circ} 33.3^{\prime} \mathrm{S}-167^{\circ} 40.6^{\prime} \mathrm{E} \\ 4152 & 12^{\circ} 33.3^{\prime} \mathrm{S}-167^{\circ} 40.6^{\prime} \mathrm{E} \\ 415 X & 12^{\circ} 33.3^{\prime} \mathrm{S}-167^{\circ} 40.6^{\prime} \mathrm{E} \\ \mathrm{CY} 11 & 12^{\circ} 32.0^{\prime} \mathrm{S}-167^{\circ} 40.4^{\prime} \mathrm{E} \\ \mathrm{CY} 31 & 12^{\circ} 31.7^{\prime} \mathrm{S}-167^{\circ} 45.1^{\prime} \mathrm{E} \\ \mathrm{CY} 34 & 12^{\circ} 31.5^{\prime} \mathrm{S}-167^{\circ} 45.2^{\prime} \mathrm{E} \\ \mathrm{CY} 36 & 12^{\circ} 32.4^{\prime} \mathrm{S}-167^{\circ} 47.2^{\prime} \mathrm{E}\end{array}$

Vot Tande Area (VOT)

$\begin{array}{ll}10 & 13^{\circ} 23.9^{\prime} \mathrm{S}-167^{\circ} 59.7^{\prime} \mathrm{E} \\ 11 & 13^{\circ} 20.9^{\prime} \mathrm{S}-167^{\circ} 57.1^{\prime} \mathrm{E} \\ 12 & 13^{\circ} 20.9^{\prime} \mathrm{S}-167^{\circ} 49.2^{\prime} \mathrm{E} \\ 4294 & 13^{\circ} 19.9^{\prime} \mathrm{S}-167^{\circ} 55.8^{\prime} \mathrm{E} \\ 4295 & 13^{\circ} 19.9^{\prime} \mathrm{S}-167^{\circ} 55.8^{\prime} \mathrm{E}\end{array}$

Hazel Holme Area (HAZ)

$14 \quad 13^{\circ} 40.0^{\prime} \mathrm{S}-168^{\circ} 30.0^{\prime} \mathrm{E}$

$15 \quad 13^{\circ} 41.0^{\prime} \mathrm{S}-168^{\circ} 29.7^{\prime} \mathrm{E}$

Coriolis Troughs

Efate area (EFA)

$\begin{array}{ll}26 & 17^{\circ} 38.6^{\prime} \mathrm{S}-169^{\circ} 24.7^{\prime} \mathrm{E} \\ 27 & 17^{\circ} 39.8^{\prime} \mathrm{S}-169^{\circ} 25.5^{\prime} \mathrm{E} \\ 28 & 17^{\circ} 38.4^{\prime} \mathrm{S}-169^{\circ} 26.4^{\prime} \mathrm{E} \\ 29 & 17^{\circ} 38.4^{\prime} \mathrm{S}-169^{\circ} 25.6^{\prime} \mathrm{E} \\ 30 & 17^{\circ} 23.3^{\prime} \mathrm{S}-169^{\circ} 02.5^{\prime} \mathrm{E} \\ 31 & 17^{\circ} 23.5^{\prime} \mathrm{S}-169^{\circ} 08.0^{\prime} \mathrm{E}\end{array}$

Erromango area (ERR)

$\begin{array}{ll}22 & 18^{\circ} 49.6^{\prime} \mathrm{S}-169^{\circ} 39.8^{\prime} \mathrm{E} \\ 24 & 18^{\circ} 47.8^{\prime} \mathrm{S}-169^{\circ} 35.1^{\prime} \mathrm{E}\end{array}$

$12^{\circ} 11.9^{\prime} \mathrm{S}-167^{\circ} 34.9^{\prime} \mathrm{E}$
$12^{\circ} 14.9^{\prime} \mathrm{S}-167^{\circ} 38.8^{\prime} \mathrm{E}$
$12^{\circ} 10.9^{\prime} \mathrm{S}-167^{\circ} 42.1^{\prime} \mathrm{E}$
$12^{\circ} 08.8^{\prime} \mathrm{S}-167^{\circ} 48.8^{\prime} \mathrm{E}$
$12^{\circ} 15.8^{\prime} \mathrm{S}-167^{\circ} 51.0^{\prime} \mathrm{E}$
$12^{\circ} 16.7^{\prime} \mathrm{S}-167^{\circ} 52.7^{\prime} \mathrm{E}$
$12^{\circ} 10.3^{\prime} \mathrm{S}-167^{\circ} 46.3^{\prime} \mathrm{E}$
$12^{\circ} 11.6^{\prime} \mathrm{S}-167^{\circ} 35.4^{\prime} \mathrm{E}$
$12^{\circ} 11.6^{\prime} \mathrm{S}-167^{\circ} 35.4^{\prime} \mathrm{E}$
$12^{\circ} 11.6^{\prime} \mathrm{S}-167^{\circ} 35.4^{\prime} \mathrm{E}$
$12^{\circ} 11.6^{\prime} \mathrm{S}-167^{\circ} 35.4^{\prime} \mathrm{E}$

$12^{\circ} 52.2^{\prime} \mathrm{S}-167^{\circ} 51.0^{\prime} \mathrm{E}$ $12^{\circ} 52.2^{\prime} \mathrm{S}-167^{\circ} 51.0^{\prime} \mathrm{E}$ $12^{\circ} 52.2^{\prime} \mathrm{S}-167^{\circ} 51.0^{\prime} \mathrm{E}$ $12^{\circ} 52.2^{\prime} \mathrm{S}-167^{\circ} 51.0^{\prime} \mathrm{E}$ $12^{\circ} 33.2^{\prime} \mathrm{S}-167^{\circ} 40.8^{\prime} \mathrm{E}$ $12^{\circ} 33.2^{\prime} \mathrm{S}-167^{\circ} 40.8^{\prime} \mathrm{E}$ $12^{\circ} 33.2^{\prime} \mathrm{S}-167^{\circ} 40.8^{\prime} \mathrm{E}$ $12^{\circ} 33.2^{\prime} \mathrm{S}-167^{\circ} 40.8^{\prime} \mathrm{E}$ $12^{\circ} 33.2^{\prime} \mathrm{S}-167^{\circ} 40.8^{\prime} \mathrm{E}$ $12^{\circ} 33.2^{\prime} \mathrm{S}-167^{\circ} 40.8^{\prime} \mathrm{E}$

$13^{\circ} 24.8^{\prime} \mathrm{S}-167^{\circ} 59.6^{\prime} \mathrm{E}$ $13^{\circ} 21.7^{\prime} \mathrm{S}-167^{\circ} 55.9^{\prime} \mathrm{E}$ $13^{\circ} 21.4^{\prime} \mathrm{S}-167^{\circ} 48.1^{\prime} \mathrm{E}$ $13^{\circ} 19.9^{\prime} \mathrm{S}-167^{\circ} 56.5^{\prime} \mathrm{E}$ $13^{\circ} 19.9^{\prime} \mathrm{S}-167^{\circ} 56.5^{\prime} \mathrm{E}$

$13^{\circ} 41.6^{\prime} \mathrm{S}-168^{\circ} 28.8^{\prime} \mathrm{E}$ $13^{\circ} 41.9^{\prime} \mathrm{S}-168^{\circ} 29.6^{\prime} \mathrm{E}$

-3800 to -2870
-2900 to -2500

$$
\begin{aligned}
& -1470 \text { to }-940 \\
& -1400 \pm 100 \\
& -1350 \text { to }-900 \\
& -1850 \text { to }-1650 \\
& -2450 \text { to }-2120 \\
& -2165 \text { to }-1930 \\
& -2038 \text { to }-1658 \\
& -915 \text { to }-459 \\
& -915 \text { to }-459 \\
& -915 \text { to }-459 \\
& -915 \text { to }-459 \\
& \\
& -2984 \text { to }-2130 \\
& -2984 \text { to }-2130 \\
& -2984 \text { to }-2130 \\
& -2984 \text { to }-2130 \\
& -1425 \text { to }-1284 \\
& -1425 \text { to }-1284 \\
& -1425 \text { to }-1284 \\
& -1425 \text { to }-1284 \\
& -1425 \text { to }-1284 \\
& -1425 \text { to }-1284 \\
& -1905 \\
& -2412 \\
& -2203 \\
& -1550
\end{aligned}
$$

-2130 to -1880
-2000 to -1550
-2200 to -1600
-2140 to -1650
-2140 to -1650

-2080 to -1850

-1960 to -1200

-1270 to -700

-980 to -600

-1270 to -1200

-1570 to -1250

-2800 to -2400

$18^{\circ} 48.8^{\prime} \mathrm{S}-169^{\circ} 37.9^{\prime} \mathrm{E}$ $18^{\circ} 47.9^{\prime} \mathrm{S}-169^{\circ} 34.9^{\prime} \mathrm{E}$ 
TABLE I

(Continued)

\begin{tabular}{llll}
\hline Location & Start & End & Depth (m) \\
\hline
\end{tabular}

(a)

Coriolis Troughs (cont.)

Erromango area (ERR) (cont.)

$25 \quad 18^{\circ} 32.4^{\prime} \mathrm{S}-169^{\circ} 34.3^{\prime} \mathrm{E}$

Futuna area (FUT)

$\begin{array}{ll}16 & 19^{\circ} 47.8^{\prime} \mathrm{S}-170^{\circ} 16.5^{\prime} \mathrm{E} \\ 17 & 19^{\circ} 47.6^{\prime} \mathrm{S}-170^{\circ} 17.2^{\prime} \mathrm{E} \\ 19 & 19^{\circ} 46.3^{\prime} \mathrm{S}-170^{\circ} 19.1^{\prime} \mathrm{E} \\ 20 & 19^{\circ} 25.0^{\prime} \mathrm{S}-169^{\circ} 54.6^{\prime} \mathrm{E} \\ 21 & 19^{\circ} 54.1^{\prime} \mathrm{S}-170^{\circ} 17.0^{\prime} \mathrm{E}\end{array}$

Anatom area (ANA)

$\begin{array}{ll}4311 & 20^{\circ} 31.0^{\prime} \mathrm{S}-170^{\circ} 00.5^{\prime} \mathrm{E} \\ 4312 & 20^{\circ} 31.0^{\prime} \mathrm{S}-170^{\circ} 00.5^{\prime} \mathrm{E} \\ 4313 & 20^{\circ} 31.0^{\prime} \mathrm{S}-170^{\circ} 00.5^{\prime} \mathrm{E} \\ 4314 & 20^{\circ} 31.0^{\prime} \mathrm{S}-170^{\circ} 00.5^{\prime} \mathrm{E} \\ 4315 & 20^{\circ} 31.0^{\prime} \mathrm{S}-170^{\circ} 00.5^{\prime} \mathrm{E} \\ 4316 & 20^{\circ} 31.0^{\prime} \mathrm{S}-170^{\circ} 00.5^{\prime} \mathrm{E} \\ 4318 & 20^{\circ} 31.0^{\prime} \mathrm{S}-170^{\circ} 00.5^{\prime} \mathrm{E} \\ 43110 & 20^{\circ} 31.0^{\prime} \mathrm{S}-170^{\circ} 00.5^{\prime} \mathrm{E} \\ 43112 & 20^{\circ} 31.0^{\prime} \mathrm{S}-170^{\circ} 00.5^{\prime} \mathrm{E} \\ 4421 & 20^{\circ} 52.6^{\prime} \mathrm{S}-170^{\circ} 00.5^{\prime} \mathrm{E} \\ 4422 & 20^{\circ} 52.6^{\prime} \mathrm{S}-170^{\circ} 00.5^{\prime} \mathrm{E} \\ 4423 & 20^{\circ} 52.6^{\prime} \mathrm{S}-170^{\circ} 00.5^{\prime} \mathrm{E} \\ 4424 & 20^{\circ} 52.6^{\prime} \mathrm{S}-170^{\circ} 00.5^{\prime} \mathrm{E} \\ 4531 & 20^{\circ} 34.0^{\prime} \mathrm{S}-170^{\circ} 02.6^{\prime} \mathrm{E} \\ 4532 & 20^{\circ} 340^{\prime} \mathrm{S}-170^{\circ} 02.6^{\prime} \mathrm{E} \\ 4533 & 20^{\circ} 340^{\prime} \mathrm{S}-170^{\circ} 02.6^{\prime} \mathrm{E} \\ 4534 & 20^{\circ} 340^{\prime} \mathrm{S}-170^{\circ} 02.6^{\prime} \mathrm{E} \\ 4641 & 20^{\circ} 02.6^{\prime} \mathrm{S}-170^{\circ} 39.8^{\prime} \mathrm{E}\end{array}$

Location

$\begin{array}{ll}18^{\circ} 31.9^{\prime} \mathrm{S}-169^{\circ} 34.8^{\prime} \mathrm{E} & -910 \text { to }-750 \\ & -3320 \text { to }-2500 \\ 19^{\circ} 46.8^{\prime} \mathrm{S}-170^{\circ} 18.3^{\prime} \mathrm{E} & -2900 \text { to }-2150 \\ 19^{\circ} 46.2^{\prime} \mathrm{S}-170^{\circ} 20.6^{\prime} \mathrm{E} & -1750 \text { to }-1550 \\ 19^{\circ} 25.6^{\prime} \mathrm{S}-169^{\circ} 55.5^{\prime} \mathrm{E} & -1400 \text { to }-1000 \\ 19^{\circ} 55.5^{\prime} \mathrm{S}-170^{\circ} 18.6^{\prime} \mathrm{E} & -3280 \text { to }-3150 \\ & \\ 20^{\circ} 30.9^{\prime} \mathrm{S}-170^{\circ} 00.7^{\prime} \mathrm{E} & -2288 \text { to }-2066 \\ 20^{\circ} 30.9^{\prime} \mathrm{S}-170^{\circ} 00.7^{\prime} \mathrm{E} & -2288 \text { to }-2066 \\ 20^{\circ} 30.9^{\prime} \mathrm{S}-170^{\circ} 00.7^{\prime} \mathrm{E} & -2288 \text { to }-2066 \\ 20^{\circ} 30.9^{\prime} \mathrm{S}-170^{\circ} 00.7^{\prime} \mathrm{E} & -2288 \text { to }-2066 \\ 20^{\circ} 30.9^{\prime} \mathrm{S}-170^{\circ} 00.7^{\prime} \mathrm{E} & -2288 \text { to }-2066 \\ 20^{\circ} 30.9^{\prime} \mathrm{S}-170^{\circ} 00.7^{\prime} \mathrm{E} & -2288 \text { to }-2066 \\ 20^{\circ} 30.9^{\prime} \mathrm{S}-170^{\circ} 00.7^{\prime} \mathrm{E} & -2288 \text { to }-2066 \\ 20^{\circ} 30.9^{\prime} \mathrm{S}-170^{\circ} 00.7^{\prime} \mathrm{E} & -2288 \text { to }-2066 \\ 20^{\circ} 30.9^{\prime} \mathrm{S}-170^{\circ} 00.7^{\prime} \mathrm{E} & -2288 \text { to }-2066 \\ 20^{\circ} \mathrm{S} 2.3^{\prime} \mathrm{S}-170^{\circ} 00.9^{\prime} \mathrm{E} & -979 \text { to }-771 \\ 20^{\circ} 52.3^{\prime} \mathrm{S}-170^{\circ} 00.9^{\prime} \mathrm{E} & -979 \text { to }-771 \\ 20^{\circ} 52.3^{\prime} \mathrm{S}-170^{\circ} 00.9^{\prime} \mathrm{E} & -979 \text { to }-771 \\ 20^{\prime} 52.3^{\prime} \mathrm{S}-170^{\circ} 00.9^{\prime} \mathrm{E} & -979 \text { to }-771 \\ 20^{\circ} 33.9^{\prime} \mathrm{S}-170^{\circ} 02.8^{\prime} \mathrm{E} & -2054 \text { to }-1923 \\ 20^{\circ} 33.9^{\prime} \mathrm{S}-170^{\circ} 02.8^{\prime} \mathrm{E} & -2054 \text { to }-1923 \\ 20^{\circ} 33.9^{\prime} \mathrm{S}-170^{\circ} 02.8^{\prime} \mathrm{E} & -2054 \text { to }-1923 \\ 20^{\circ} 33.9^{\prime} \mathrm{S}-170^{\circ} 02.8^{\prime} \mathrm{E} & -2054 \text { to }-1923 \\ 20^{\circ} 02.8^{\prime} \mathrm{S}-170^{\circ} 40.3^{\prime} \mathrm{E} & -1144 \text { to }-1055\end{array}$

(b)

\section{Jean Charcot Troughs}

Vanikoro area (VAN)

$\begin{array}{ll}1 & \text { central volcanic complex } \\ 2 & \text { central volcanic complex } \\ 3 & \text { central volcanic complex } \\ 5 & \text { central volcanic complex } \\ 6 & \text { Duff Ridge (eastern limit of JCT) } \\ 7 & \text { Duff Ridge (eastern limit of JCT) } \\ 3321 & \text { central volcanic complex } \\ 3151 & \text { central volcanic complex } \\ 3154 & \text { central volcanic complex } \\ 3152 & \text { central volcanic complex } \\ 3155 & \text { central volcanic complex }\end{array}$

Tikopia area (TIK)

$\begin{array}{ll}3981 & \text { central graben (eastern wall) } \\ 3981 \mathrm{X} & \text { central graben (eastern wall) } \\ 3982 & \text { central graben (eastern wall) } \\ 3983 & \text { central graben (eastern wall) } \\ 4150 & \text { western seamount (W slope) }\end{array}$

(station 33)

(station 31)

(station 31 )

(station 31)

(station 31)

(station 39)

(station 39)

(station 39)

(station 39)

(station 41) 
(b)

Jean Charcot Troughs (cont.)

Tikopia area (TIK) (cont.)

4151 western seamount (W slope)

4153 western seamount (W slope)

4155 western seamount (W slope)

4152 western seamount (W slope)

415X western seamount (W slope)

CY11 western seamount (NW slope)

CY31 eastern seamount (NW slope)

CY34 eastern seamount (NW slope)

CY36 eastern seamount (NW slope)

(station 41) 2

(station 41) 2

(station 41) 2

(station 41) 2

(station 41) 2

(station 41) 3

(station 41) 3

(station 41) 3

(station 41) 3

Vot Tande area (VOT)

10 small isolated seamount (east of central horst)

11 central horst (E slope)

12 Vot Tande island basement (SE flank)

$4294 \quad$ central horst (W slope)

$4295 \quad$ central horst (W slope)

$\begin{array}{ll} & 1 \\ & 1 \\ & 1 \\ \text { (station 42) } & 2 \\ \text { (station 42) } & 2\end{array}$

Hazel Holme Area (HAZ)

14 southern scarp of western termination (basis)

15 southern scarp of western termination (top)

\section{Coriolis Troughs}

Efate area (EFA)

26

27

28

29

30

31

\section{Erromango area (ERR)}

22

24

25

western scarp of northwestern termination (basis)

western scarp of northwestern termination (top)

isolated volcanic cone to the north of the trough

eastern flank (basis) of eastern graben

eastern flank (basis) of eastern graben

eastern flank (middle) of eastern graben

eastern flank (top) of eastern graben

western volcanic cone to the north of the trough

eastern volcanic cone to the north of the trough

Futuna area (FUT)

16 southeastern scarp of the trough (basis)

17

19

20

21

southeastern scarp of the trough (middle)

southeastern scarp of the trough (top)

volcanic cone on the NW flank of the trough

small southern relief on the trough bottom

Anatom area (ANA)

4311 to 43112 small ridge, within the en echelon termination of the trough (station 43)

4421 to 4424 small seamount outside the trough, on the central chain axis (station 44)

4531 to 4534

4641

eastern flank of the en-echelon termination of the trough (station 45)

volcanic cone (Mt Yokosuka) to the east of the trough (station 46)

${ }^{a}$ The CY samples were picked up in situ by Cyana submersible.

${ }^{b} 1$ : SEAPSO 2 (1985); 2: KAIYO 89 (1989), with STARMER station number; 3: SAVANES (1991), with STARMER station number; 4: YOKOSUKA 90 (1991), with STARMER station number. 

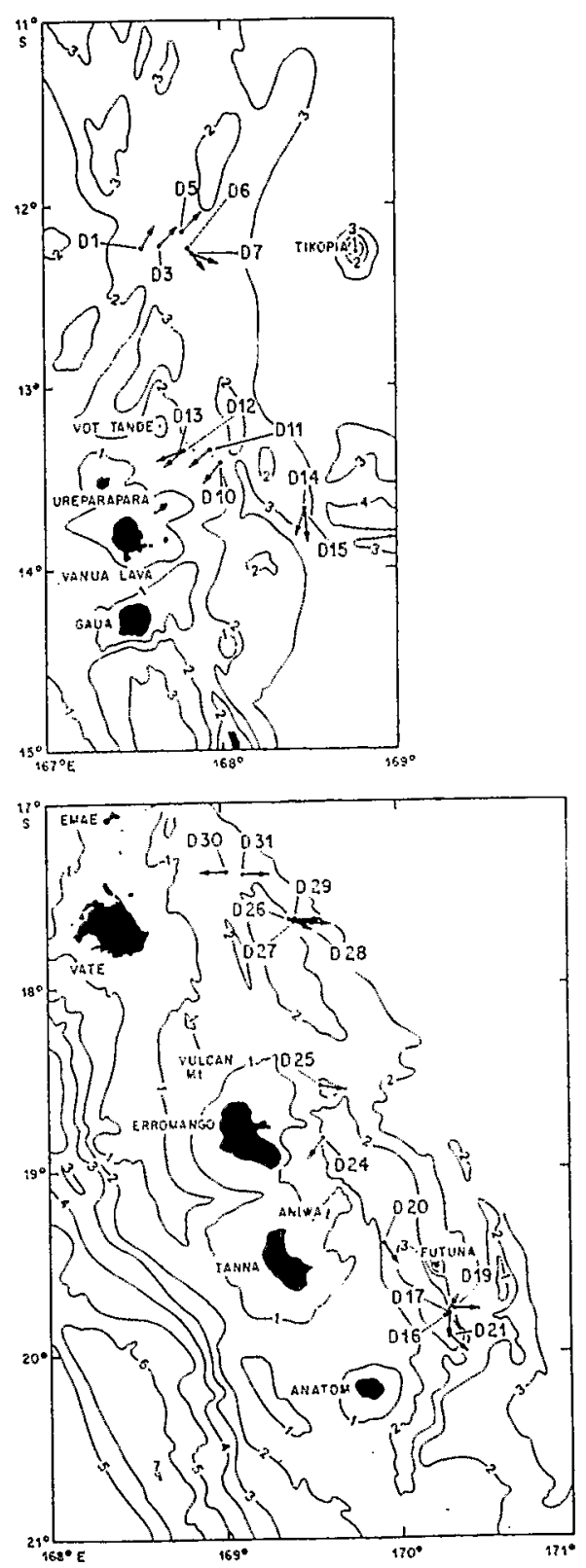

FIGURE 5.14. Location of volcanic samples dredged during the SEAPSO 2 cruise in the Jean-Charcot troughs (top) and Coriolis troughs (bottom). Coordinates and structural setting of these samples are listed in Tables IaIb c sample D1 in Fig. $5.14=$ sample 1 in Tables I-IIl; sample D25 in Fig. $5.14=$ sample 25 in Tables I-III, etc.). Bathymetry in $\mathrm{km}$. Vate $=$ Efate. Gaua $=$ Santa Maria in Fig. 5.2 (From Monjaret ot al., 1991).

The $\mathrm{K}_{2} \mathrm{O}$ versus $\mathrm{SiO}_{2}$ diagram (Fig. 5.16) emphasizes two trends, similar to those for the New Hebrides central chain volcanics. A lower- $\mathrm{K}_{2} \mathrm{O}$ suite encompasses most samples from the northern Jean-Charcot troughs: all the VAN volcanics (except the $7 \mathrm{M} 4$ andesite), including the high- $\mathrm{Na}$ /low-K dacites studied by Nakada et al. (1994); most of the TIK volcanics. except for four samples with higher- $\mathrm{K}_{2} \mathrm{O}$ contents $(3981,3981 \mathrm{X}, 3982,3983$ : Table II), which are calc-alkaline andesites; and the island-arc tholeiites of the VOT area. A higher- $\mathrm{K}_{2} \mathrm{O}$ suite is represented in the southern Coriolis troughs by the volcanics from the 


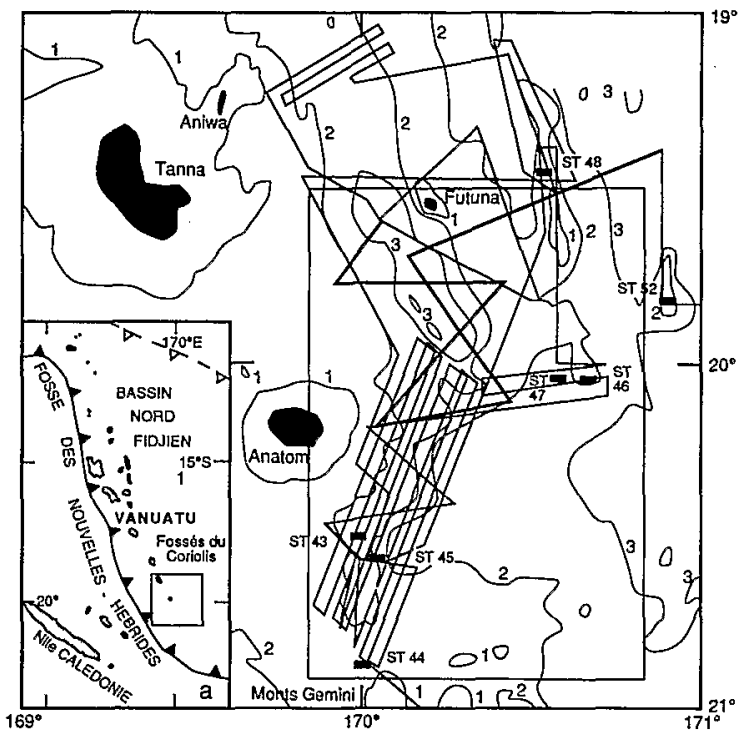

FIGURE 5.15. Location of samples dredged during the YOKOSUKA 90 cruise in the southern Coriolis troughs. Coordinates and structural setting of these samples are listed in Tables Ia-Ib (ST $43=$ samples 4311 to 43112, ST 44 = samples 4421 to 4424 , ST $45=$ samples 4531 to 4534, ST $46=$ sample 4641 in Tables I and II). Bathymetry in km (From Eissen et al., unpublished information, 1994).

Efate (EFA) and Anatom (ANA) areas. The ANA backarc volcanics, however, differ from the Anatom Island volcanics, the latter belonging mainly to a lower- $\mathrm{K}_{2} \mathrm{O}$ suite; in contrast, hyper-K dacites from Efate area (EFA; i group on Table II) show a close chemical similarity with acidic pumices of Efate island (Coulon et al., 1979).

All other groups of volcanics from the backarc areas display an intermediate $\mathrm{K}_{2} \mathrm{O}$ trend with respect to $\mathrm{SiO}_{2}$ contents.

3.3.3.2. Trace Elements. Various trace elements are plotted against $\mathrm{SiO}_{2}$ in Fig. 5.17. LILE (e.g., Rb, Ba, and Th) and HFSE (e.g., Nb, Ta, Hf, Sm, $\mathrm{Zr}$ and $\mathrm{Y}$ ) classically show a steady increase with increasing $\mathrm{SiO}_{2}$. In contrast, $\mathrm{Ni}$ behaves compatibly. $\mathrm{Rb}$ vs. $\mathrm{SiO}_{2}, \mathrm{Ba}$ vs. $\mathrm{SiO}_{2}$, and $\mathrm{Th}$ vs. $\mathrm{SiO}_{2}$ diagrams (Fig. 5.17) look quite similar, and all emphasize the distinction between the lower- $\mathrm{K}_{2} \mathrm{O}$ suites (most of JCT samples) and the higher- $\mathrm{K}_{2} \mathrm{O}$ suites (e.g., EFA samples). Contrasting with other LILE, Sr contents decrease with increasing $\mathrm{SiO}_{2}$ contents. This trend, likely due to plagioclase fractionation, is more pronounced in the felsic lavas $\left(\mathrm{SiO}_{2}>60 \%\right)$.

The $\mathrm{Ba} / \mathrm{Zr}$ ratio, often considered as an indicator of the extent of "arc signature" (Fryer et al., 1990), varies greatly in the NHBAT volcanics. VAN and HAZ samples (Table II) have the lowest $\mathrm{Ba} / \mathrm{Zr}$ ratio, usually between 0.4 and 1 . These values are still well above the ratio for N-MORB (0.08; Sun and McDonough, 1989). All other samples have a $\mathrm{Ba} / \mathrm{Zr}$ ratio ranging between 1 and 5 (or more), typical of volcanics from island-arc environments.

On the $\mathrm{Th} / \mathrm{Yb}$ vs. $\mathrm{Ta} / \mathrm{Yb}$ diagram (Pearce, 1983) the distinction between northern and southern troughs is neat (Fig. 5.18). The geochemistry of all Coriolis samples (EFA, ERR, FUT; southern troughs) is influenced by a subduction component, these samples having relatively low $\mathrm{Ta} / \mathrm{Yb}$ ratios and high $\mathrm{Th} / \mathrm{Yb}$ ratios. In contrast, this subduction component is 
less pronounced, or even absent, in the Jean-Charcot (VAN, VOT) and Hazel Holme (HAZ) samples (northern troughs).

The chondrite-normalized REE patterns and N-MORB normalized "spider diagrams" of the different petrological types encountered in the NHBAT are shown in Fig. 5.19. MORB and BABB dredged in the VAN area present similar flat, or slightly LREE-depleted, patterns, as typically observed in N-MORB or BABB (Saunders and Tarney, 1984; Eissen et al., 1991; 1994; Sinton et al. 1994). MORB from the Hazel Holme area are significantly LILE- and LREE-enriched, compared to the VAN N-MORB, and are therefore classified as E-MORB.

The LILE ( $\mathrm{Ba}, \mathrm{Rb}$. Sr) enrichment and HFSE ( Ta, Nb, Zr. Ti, Y, Yb) depletion, relative to N-MORB, characteristic of island-arc basic and intermediate volcanics (Gill, 1981; Thorpe, 1982; Wilson, 1989), is particularly clear in Fig. 5.19 (see, for example, IAT types b. c. d of Table II from the Coriolis troughs). As noted, K-rich felsic lavas-that is. highand hyper-K dacites (types $\mathrm{h}$ and $\mathrm{i}$ of Table II)-usually show a strongly-LREE-enriched pattern. often accompanied by a $\mathrm{Sr}$ depletion due to plagioclase fractionation.

In summary, even though no oceanic spreading actually occurs in the New Hebrides backarc troughs, some BABB dredged in their very northern part (central volcanic complex of the Vanikoro area. Jean-Charcot troughs) still show evidence of a limited trend toward an aborted marginal basin, with an age between 3.9 and 1.1 Ma (Tables I-III). A neat petrological dichotomy marks these troughs. Volcanics from the southern troughs (CT) present all the classical characteristics of arc-related, orogenic magmas. In contrast, the northern troughs (JCT) are floored with volcanics reflecting more complex influences, with compositions trending between BABB and more typical arc lavas.

The significant extension and thick sedimentary input that characterize the central and northern New Hebrides arc platform have been noted, the Aoba and Vanikoro-Torres basins (Fig. 5.13) having no equivalent in the southern part of the arc. The geographical proximity of the Vanikoro-Torres Basin and JCT, both affected by extensional stresses, raises therefore the question of their possible genetical relationship. No petrological or geophysical argument, however, relates BABB formation in the JCT between 3.9 and 1.1 $\mathrm{Ma}$ to extension in the Vanikoro-Torres Basin.

\subsection{Backarc Hydrothermal Activity and Ferromanganese Crusts}

\subsubsection{Backarc Hydrothermal Activity}

During the KAIYO 89 cruise, five hydrocasts were performed in the JCT for conductivity-temperature-depth (CTD) profiles and methane $\left(\mathrm{CH}_{4}\right)$ analysis. Following onboard analyses, one hydrocast gave a distinct $\mathrm{CH}_{4}$ anomaly, but this was not accompanied by a thermal anomaly. This water sampling was located in the Vanikoro area, at station $31\left(12^{\circ} 12.50^{\prime} \mathrm{S}-167^{\circ} 38.77^{\prime} \mathrm{E}\right.$ ). between $1617 \mathrm{~m}$ depth and sea level (Fig. 5.5). The $\mathrm{CH}_{4}$ anomaly, which is possibly indicative of an hydrothermal plume, was found at $1200 \mathrm{~m}$ depth-that is, $400 \mathrm{~m}$ above the sea bottom (KAIYO 89 Cruise Report, 1990). It was characterized by an extremely high methane/manganese ratio of 8 , similar to that observed in the Okinawa Trough (Nojiri and Ishibashi. 1991).

Five heat flow stations were also run during this cruise, using a gravity corer, in small sedimentary basins within the JCT (three measurements in the Vanikoro area, one in the Tikopia area. one in the Vot Tande area). Heat flow values vary between 23 and $161 \mathrm{~mW} / \mathrm{m}^{2}$. 
TABLE II

Chemical Whole-Rock Analyses of Volcanic Samples ${ }^{a}$

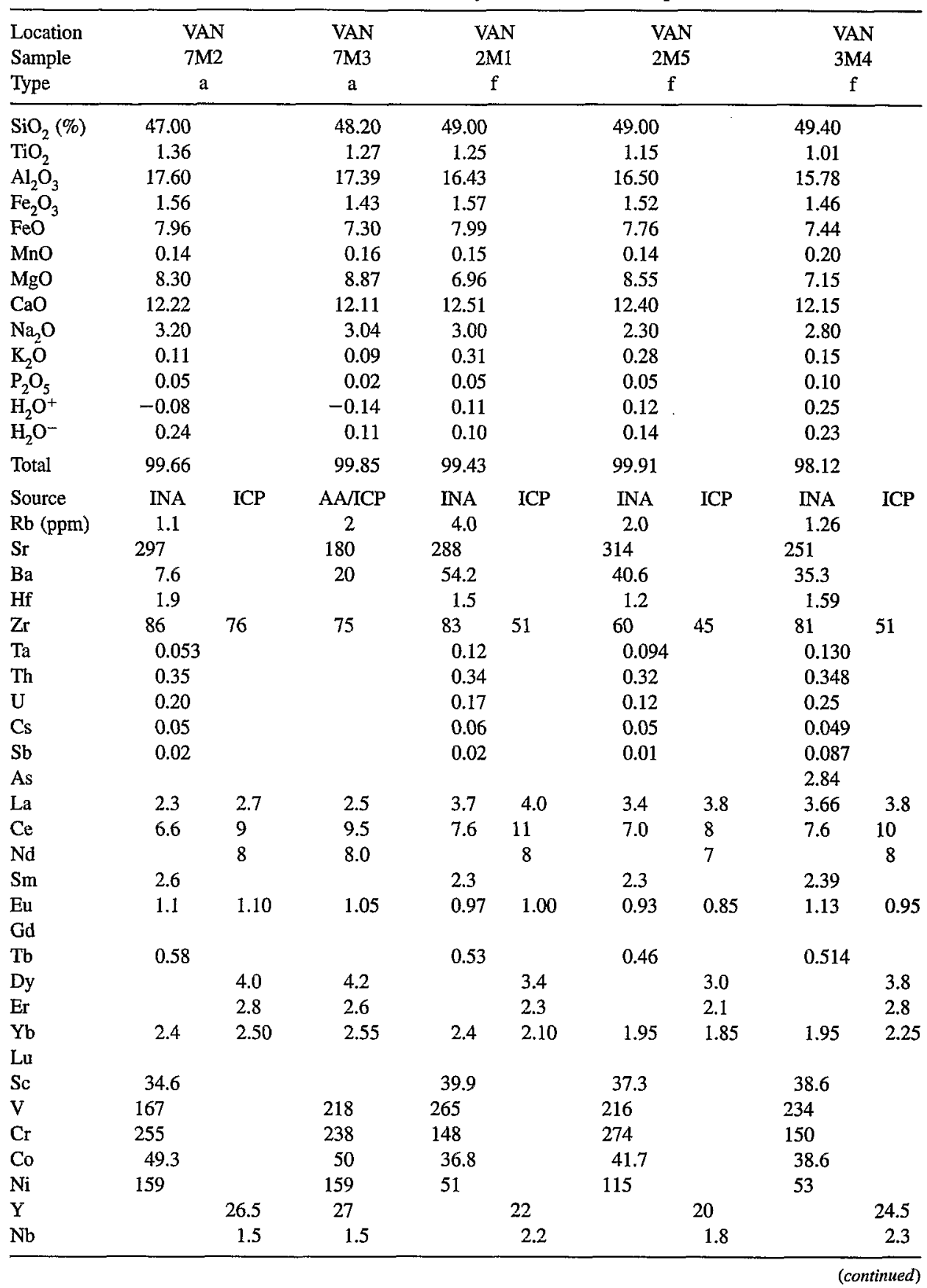


TABLE /I

(Continued)

\begin{tabular}{|c|c|c|c|c|c|c|c|c|c|c|}
\hline $\begin{array}{l}\text { Location } \\
\text { Sample } \\
\text { Type } \\
\end{array}$ & $\begin{array}{c}\text { VAI } \\
5 \mathrm{M} \\
\mathrm{f}\end{array}$ & & $\begin{array}{l}\text { VAN } \\
5 \mathrm{M} 1\end{array}$ & $\begin{array}{r}\mathrm{VA} \\
6 \mathrm{M} \\
\mathrm{c}\end{array}$ & & $\begin{array}{r}\text { VAl } \\
5 \mathrm{M} \\
\mathrm{f}\end{array}$ & & $\begin{array}{c}\text { VAN } \\
3321 \\
b\end{array}$ & $\begin{array}{r}\text { VAf } \\
3 \mathrm{M} \\
\mathrm{f}\end{array}$ & \\
\hline $\mathrm{SiO}_{2}$ & 49.50 & & 50.15 & 50.80 & & 51.10 & & 49.28 & 52.20 & \\
\hline $\mathrm{TiO}_{2}$ & 0.85 & & 0.79 & 1.03 & & 0.76 & & 0.55 & 1.22 & \\
\hline $\mathrm{Al}_{2} \mathrm{O}_{3}$ & 16.65 & & 16.53 & 16.90 & & 15.90 & & 18.01 & 15.83 & \\
\hline $\mathrm{Fe}_{2} \mathrm{O}_{3}$ & 1.52 & & 1.37 & 1.67 & & 1.39 & & 9.02 & 1.59 & \\
\hline $\mathrm{FeO}$ & 7.76 & & 6.99 & 8.53 & & 7.08 & & & 8.10 & \\
\hline $\mathrm{MnO}$ & 0.16 & & 0.16 & 0.16 & & 0.16 & & 0.17 & 0.18 & \\
\hline $\mathrm{MgO}$ & 7.35 & & 7.51 & 5.18 & & 7.15 & & 7.11 & 5.51 & \\
\hline $\mathrm{CaO}$ & 13.05 & & 12.83 & 10.80 & & 12.11 & & 13.70 & 9.86 & \\
\hline $\mathrm{Na}_{2} \mathrm{O}$ & 2.44 & & 2.33 & 3.02 & & 2.30 & & 1.74 & 3.51 & \\
\hline $\mathrm{K}_{2} \mathrm{O}$ & 0.31 & & 0.32 & 0.61 & & 0.28 & & 0.28 & 0.36 & \\
\hline $\mathrm{P}_{2} \mathrm{O}_{5}$ & 0.05 & & 0.05 & 0.10 & & 0.05 & & 0.10 & 0.15 & \\
\hline $\mathrm{H}_{2} \mathrm{O}^{+}$ & 0.03 & & 0.42 & 0.49 & & 0.13 & & & 0.16 & \\
\hline $\mathrm{H}_{2} \mathrm{O}^{-}$ & 0.11 & & 0.19 & 0.27 & & 0.18 & & & 0.21 & \\
\hline Total & 99.78 & & 99.64 & 99.56 & & 98.59 & & 99.96 & 98.88 & \\
\hline Source & INA & ICP & $\mathrm{AA} / \mathrm{ICP}$ & INA & $\mathrm{ICP}$ & INA & $\mathrm{ICP}$ & XRF/ICP & INA & ICP \\
\hline $\mathrm{Rb}$ & 3.4 & & 4 & 7.6 & & 3 & & 3 & 4.3 & \\
\hline $\mathrm{Sr}$ & 295 & & 227 & 291 & & 288 & & 298 & 258 & \\
\hline $\mathrm{Ba}$ & 42 & & 60 & 78 & & 45.8 & & 167 & 72.7 & \\
\hline $\mathrm{Hf}$ & 1.2 & & & 1.8 & & 1.15 & & & 2.19 & \\
\hline $\mathrm{Zr}$ & 40 & 42 & 41 & 66 & 63 & 49 & 43 & 27 & 84 & 74 \\
\hline $\mathrm{Ta}$ & 0.079 & & & 0.14 & & 0.073 & & & 0.195 & \\
\hline Th & 0.23 & & & 0.52 & & 0.237 & & & 0.470 & \\
\hline $\mathrm{U}$ & 0.06 & & & 0.26 & & 0.103 & & & 0.24 & \\
\hline Cs & 0.11 & & & 0.17 & & 0.110 & & & 0.083 & \\
\hline $\mathrm{Sb}$ & 0.05 & & & 0.07 & & 0.037 & & & 0.070 & \\
\hline As & & & & 1.1 & & 0.44 & & & 1.66 & \\
\hline $\mathrm{La}$ & 2.5 & 3.1 & 3.0 & 4.9 & 5.8 & 2.67 & 2.7 & 3.0 & 4.80 & 4.9 \\
\hline $\mathrm{Ce}$ & 7.0 & 9 & 10 & 10.9 & 13 & 5.4 & 10 & 6.8 & 9.6 & 14 \\
\hline $\mathrm{Nd}$ & & 6 & 6 & & 10 & & 6.5 & 5.2 & & 10 \\
\hline $\mathrm{Sm}$ & 1.8 & & & 2.8 & & 1.77 & & 2.0 & 2.95 & \\
\hline $\mathrm{Eu}$ & 0.72 & 0.80 & 0.75 & 0.95 & 1.05 & 0.73 & 0.75 & 0.71 & 1.17 & 1.25 \\
\hline $\mathrm{Gd}$ & & & & & & & & 2.0 & & \\
\hline $\mathrm{Th}$ & 0.39 & & & 0.51 & & 0.366 & & & 0.628 & \\
\hline Dy & & 2.8 & 2.8 & & 3.4 & & 2.8 & 2.2 & & 4.4 \\
\hline Er & & 1.6 & 2.0 & & 2.2 & & 1.8 & 1.4 & & 2.9 \\
\hline $\mathrm{Yb}$ & 1.9 & 1.65 & 1.70 & 2.3 & 2.10 & 1.42 & 1.75 & 1.3 & 2.67 & 2.70 \\
\hline Lu & & & & & & & & 0.19 & & \\
\hline $\mathrm{Sc}$ & 38.4 & & & 34.0 & & 37.8 & & & 32.0 & \\
\hline V & 196 & & 243 & 258 & & 240 & & 240 & 278 & \\
\hline $\mathrm{Cr}$ & 141 & & 144 & 26 & & 153 & & 61 & 13 & \\
\hline Co & 38.1 & & 34 & 32.2 & & 37.3 & & & 32.8 & \\
\hline $\mathrm{Ni}$ & 52 & & 48 & 26 & & 48 & & 52 & 23 & \\
\hline Y & & 18 & 18 & & 23 & & 18 & 11 & & 29 \\
\hline $\mathrm{Nb}$ & & 1.8 & 2 & & 2.7 & & 1.2 & 1 & & 3 \\
\hline
\end{tabular}


TABLE $\|$

(Continued)

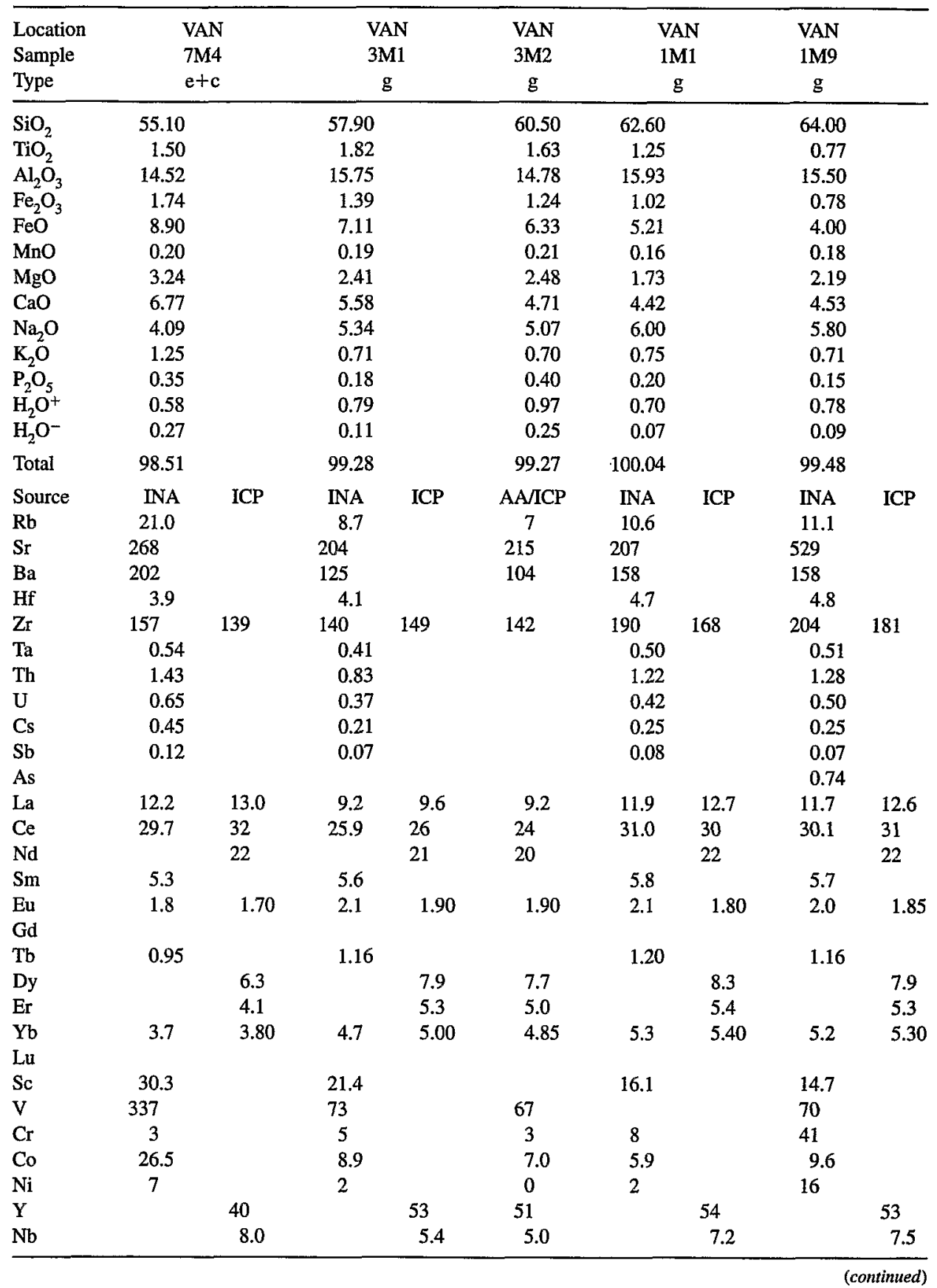


TABLE II

(Continued)

\begin{tabular}{|c|c|c|c|c|c|c|c|}
\hline $\begin{array}{l}\text { Location } \\
\text { Sample }\end{array}$ & $\begin{array}{l}\text { VAN } \\
1 M 8\end{array}$ & $\begin{array}{l}\text { VAN } \\
\text { lM55 }\end{array}$ & $\begin{array}{l}\text { VAN } \\
\text { lM3 }\end{array}$ & $\begin{array}{l}\text { VAN } \\
3151\end{array}$ & $\begin{array}{l}\text { VAN } \\
3154\end{array}$ & $\begin{array}{l}\text { VAN } \\
3152\end{array}$ & $\begin{array}{l}\text { VAN } \\
3155\end{array}$ \\
\hline Type & $\mathrm{g}$ & $\mathrm{g}$ & $\mathrm{g}$ & $\mathrm{g}$ & $\mathrm{g}$ & $\mathrm{g}$ & $\mathrm{g}$ \\
\hline $\mathrm{SiO}_{2}$ & 65.20 & 67.00 & 67.50 & 66.43 & 66.96 & 66.77 & 66.09 \\
\hline $\mathrm{TiO}_{2}$ & 0.90 & 0.86 & 0.78 & 0.85 & 0.86 & 0.95 & 0.96 \\
\hline $\mathrm{Al}_{2} \mathrm{O}_{3}$ & 16.20 & 14.99 & 14.60 & 15.33 & 15.52 & 15.38 & 15.28 \\
\hline $\mathrm{Fe}_{2} \mathrm{O}_{3}$ & 0.75 & 0.68 & 0.68 & 1.40 & 1.20 & 5.23 & 5.26 \\
\hline $\mathrm{FeO}$ & 3.84 & 3.46 & 3.48 & 3.00 & 3.22 & & \\
\hline $\mathrm{MnO}$ & 0.15 & 0.15 & 0.16 & 0.16 & 0.16 & 0.20 & 0.20 \\
\hline $\mathrm{MgO}$ & 1.21 & 1.17 & 1.04 & 1.19 & 1.17 & 1.16 & 1.17 \\
\hline $\mathrm{CaO}$ & 3.56 & 3.27 & 2.79 & 3.18 & 3.23 & 3.26 & 3.29 \\
\hline $\mathrm{Na}_{2} \mathrm{O}$ & 6.55 & 6.12 & 6.12 & 5.56 & 6.21 & 6.76 & 6.71 \\
\hline $\mathrm{K}_{2} \mathrm{O}$ & 0.88 & 0.83 & 0.93 & 0.85 & 0.86 & 0.92 & 0.91 \\
\hline $\mathrm{P}_{2} \mathrm{O}_{5}$ & 0.15 & 0.25 & 0.15 & 0.24 & 0.25 & 0.20 & 0.22 \\
\hline $\mathrm{H}_{2} \mathrm{O}^{+}$ & 0.72 & 0.73 & 0.90 & 0.73 & 0.60 & & \\
\hline $\mathrm{H}_{2} \mathrm{O}^{-}$ & 0.05 & 0.11 & 0.15 & 1.28 & 0.08 & & \\
\hline
\end{tabular}

\begin{tabular}{|c|c|c|c|c|c|c|c|c|c|}
\hline Total & 100.16 & & 99.62 & 99.28 & 100.20 & 100.32 & 100.83 & 100.09 & \\
\hline Source & INA & ICP & $\mathrm{AA} / \mathrm{ICP}$ & $\mathrm{AA} / \mathrm{ICP}$ & $\mathrm{XRF} / \mathrm{ICP}$ & XRF/ICP & $\mathrm{XRF} / \mathrm{ICP}$ & XRF/ICP & \\
\hline $\mathrm{Rb}$ & 12.4 & & 11 & 13 & 13.5 & 14.2 & 13 & 13 & \\
\hline $\mathrm{Sr}$ & 148 & & 178 & 149 & 172 & 174 & 164 & 164 & \\
\hline $\mathrm{Ba}$ & 186 & & 165 & 163 & 193 & 193 & 211 & & \\
\hline $\mathrm{Hf}$ & 5.4 & & & & & & & & \\
\hline $\mathrm{Zr}$ & 213 & 205 & 204 & 214 & 220 & 223 & 227 & 229 & \\
\hline $\mathrm{Ta}$ & 0.60 & & & & & & & & \\
\hline Th & 1.53 & & & & 1.4 & & & & \\
\hline $\mathrm{U}$ & 0.50 & & & & & & & & \\
\hline $\mathrm{Cs}$ & 0.30 & & & & & & & & \\
\hline $\mathrm{Sb}$ & 0.08 & & & & & & & & \\
\hline As & 1.3 & & & & & & & & \\
\hline $\mathrm{La}$ & 13.7 & 14.5 & 14.7 & 15 & 14.8 & 15.0 & 15.4 & 14.8 & \\
\hline $\mathrm{Ce}$ & 28.0 & 34 & 37 & 37 & 32 & 33 & 36.3 & 33.9 & \\
\hline Nd & & 24 & 25 & 25 & 24 & 25 & 22.8 & 21.7 & \\
\hline Sm & 6.1 & & & & & & 7.6 & 7.2 & \\
\hline Eu & 1.94 & 2.05 & 1.95 & 2.00 & 2.00 & 1.95 & 2.2 & 2.0 & \\
\hline $\mathrm{Gd}$ & & & & & & & 7.9 & 7.2 & \\
\hline Th & 1.23 & & & & & & & & \\
\hline Dy & & 8.6 & 8.8 & 10.0 & 8.6 & 8.8 & 8.7 & 7.9 & \\
\hline Er & & 5.6 & 5.9 & 6.1 & 5.5 & 5.8 & 5.9 & 5.2 & \\
\hline $\mathrm{Yb}$ & 6.2 & 5.85 & 5.95 & 0.10 & 5.70 & 5.75 & 6.1 & 5.3 & - \\
\hline $\mathrm{Lu}$ & & & & & & & 0.89 & 0.80 & - \\
\hline $\mathrm{Sc}$ & 11.1 & & & & & & & & \\
\hline V & & & 38 & 15 & 22 & 20 & 29 & 24 & $\because$ \\
\hline $\mathrm{Cr}$ & & & 3 & 0 & 2 & 2 & & & \\
\hline $\mathrm{Co}$ & 4.9 & & 4 & 2 & & & & & \\
\hline $\mathrm{Ni}$ & 2.3 & & 0 & 0 & 5 & 5 & & & \\
\hline $\mathrm{Y}$ & & 59 & 60 & 61 & 52.2 & 52.6 & 52 & 46 & \\
\hline $\mathrm{Nb}$ & & 8.7 & 8.8 & 9.1 & 8.5 & 8.5 & 10 & 9 & \\
\hline
\end{tabular}


TABLE II

(Continued)

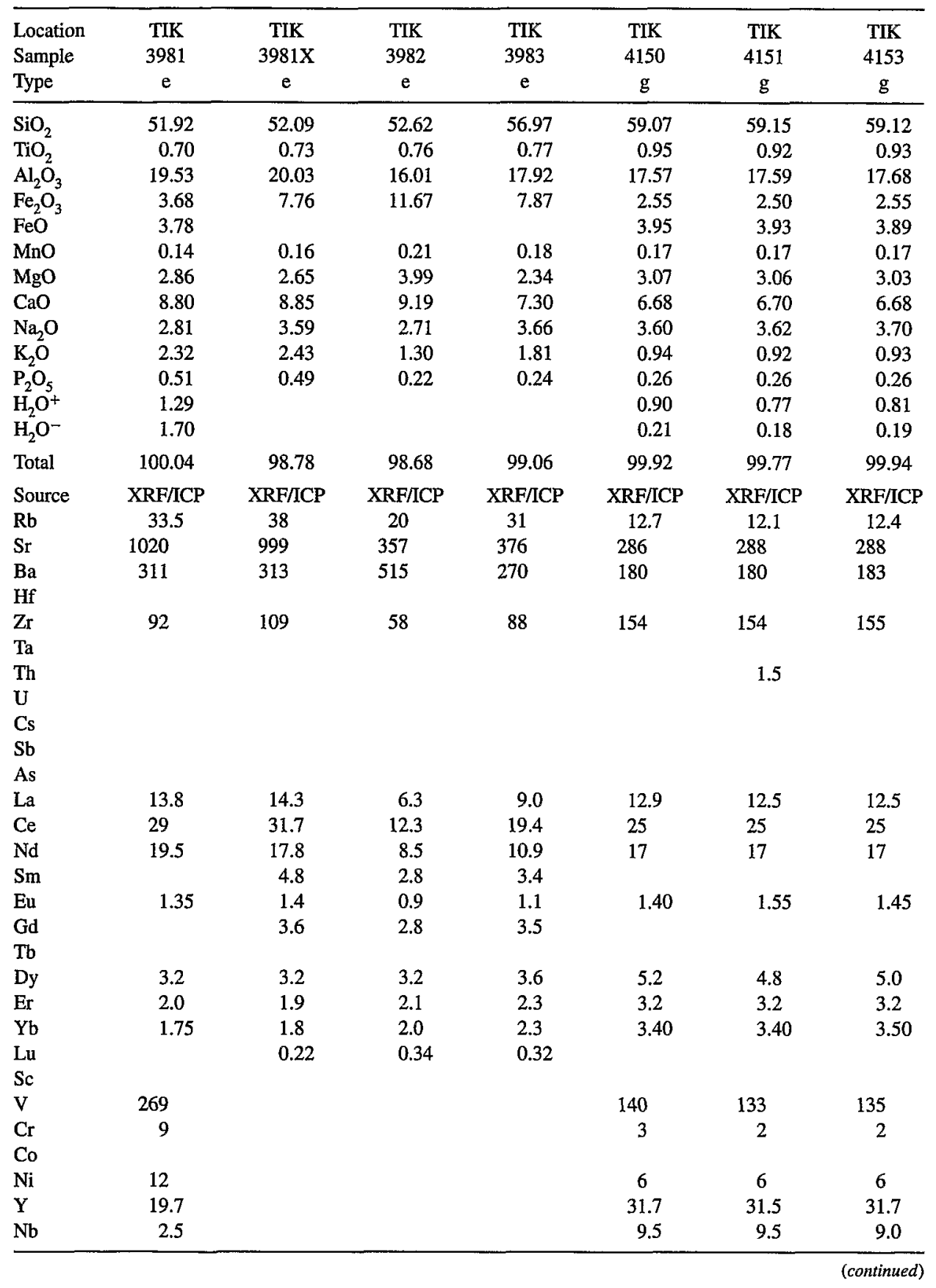


TABLE /

(Continued)

\begin{tabular}{|c|c|c|c|c|c|c|c|}
\hline Location & $\begin{array}{l}\text { TIK } \\
4155\end{array}$ & $\begin{array}{c}\text { TIK } \\
4152\end{array}$ & $\begin{array}{c}\text { TIK } \\
415 \mathrm{X}\end{array}$ & $\begin{array}{c}\text { TIK } \\
\text { CYII }\end{array}$ & $\begin{array}{c}\text { TIK } \\
\text { CY31 }\end{array}$ & $\begin{array}{c}\text { TIK } \\
\text { CY34 }\end{array}$ & $\begin{array}{c}\text { TIK } \\
\text { CY36 }\end{array}$ \\
\hline Type & $\mathrm{g}$ & $\mathrm{g}$ & $\mathrm{g}$ & $g$ & $c$ & $c$ & $c$ \\
\hline $\mathrm{SiO}_{2}$ & 59.10 & 58.48 & 58.48 & 61.55 & 53.66 & 53.71 & 54.79 \\
\hline $\mathrm{TiO}_{2}$ & 0.93 & 1.01 & 0.99 & 0.62 & 1.34 & 1.37 & 0.92 \\
\hline $\mathrm{Al}_{2} \check{\mathrm{O}}_{3}$ & 17.54 & 17.54 & 17.60 & 17.60 & 16.18 & 17.76 & 17.79 \\
\hline $\mathrm{Fe}_{2} \mathrm{O}_{3}$ & 2.57 & 7.29 & 7.22 & 5.26 & 8.91 & 9.23 & 9.00 \\
\hline $\mathrm{FeO}$ & 3.88 & & & & & & \\
\hline $\mathrm{MnO}$ & 0.17 & 0.20 & 0.20 & 0.16 & 0.17 & 0.17 & 0.16 \\
\hline $\mathrm{MgO}$ & 3.07 & 2.90 & 2.92 & 2.19 & 5.66 & 5.22 & 4.28 \\
\hline $\mathrm{CaO}$ & 6.70 & 6.77 & 6.74 & 5.12 & 9.07 & 9.60 & 9.28 \\
\hline $\mathrm{Na}_{2} \mathrm{O}$ & 4.41 & 4.64 & 4.73 & 5.27 & 3.90 & 3.29 & 3.40 \\
\hline $\mathrm{K}_{2} \mathrm{O}$ & 0.94 & 0.97 & 0.98 & 1.06 & 0.72 & 0.70 & 0.65 \\
\hline $\mathrm{P}_{2} \mathrm{O}_{3}$ & 0.26 & 0.23 & 0.24 & 0.21 & 0.22 & 0.15 & 0.14 \\
\hline $\mathrm{H}_{2} \mathrm{O}^{+}$ & 0.73 & & & & & & \\
\hline $\mathrm{H}_{2} \mathrm{O}^{-}$ & 0.22 & & & & & & \\
\hline Total & 100.52 & 100.03 & 100.10 & 99.04 & 99.83 & 101.20 & 100.41 \\
\hline Source & $\mathrm{XRF/ICP}$ & $\mathrm{XRF} / \mathrm{ICP}$ & XRF/ICP & XRF/ICP & XRF/ICP & $\mathrm{XRF/ICP}$ & $\mathrm{XRF} / \mathrm{ICP}$ \\
\hline $\mathrm{Rb}$ & 12.5 & 13 & I1 & 17 & 11 & 11 & 9 \\
\hline $\mathrm{Sr}$ & 287 & 273 & 265 & 238 & 178 & 238 & 286 \\
\hline $\mathrm{Ba}$ & 188 & 217 & 196 & & & & \\
\hline \multicolumn{8}{|l|}{$\mathrm{Hf}$} \\
\hline $\mathrm{Zr}$ & 155 & 167 & 163 & & & & \\
\hline \multicolumn{8}{|l|}{$\mathrm{Ta}$} \\
\hline Th & 1.30 & & & 3 & 1 & 2 & 1 \\
\hline U & & & & 2 & 1 & 1 & 1 \\
\hline \multicolumn{8}{|l|}{ Cs } \\
\hline \multicolumn{8}{|l|}{$\mathrm{Sb}$} \\
\hline \multicolumn{8}{|l|}{ As } \\
\hline $\mathrm{La}$ & 12.7 & 12.6 & 12.2 & 13.3 & 8.4 & 4.9 & 5.3 \\
\hline $\mathrm{Ce}$ & 27 & 28.7 & 27.2 & 27.1 & 22.4 & 11.9 & 11.9 \\
\hline Nd & 17 & 15.8 & 15.5 & 14.6 & 16.5 & 9.t & 8.6 \\
\hline $\operatorname{Sm}$ & & 4.8 & 4.9 & 4.0 & 6.2 & 3.5 & 3.0 \\
\hline Eu & 1.50 & 1.5 & 1.5 & 1.2 & 1.8 & 1.2 & 1.0 \\
\hline $\mathrm{Gd}$ & & 4.6 & 4.6 & 3.6 & 6.2 & 4.0 & 3.0 \\
\hline \multicolumn{8}{|l|}{$\mathrm{Tb}$} \\
\hline Dy & 5.1 & 5.1 & 5.1 & 3.9 & 6.9 & 4.3 & 3.3 \\
\hline $\mathrm{Er}$ & 3.4 & 3.4 & 3.2 & 2.5 & 4.2 & 2.7 & 2.1 \\
\hline Yb & 3.50 & 3.5 & 3.3 & 2.7 & 4.1 & 2.6 & 1.9 \\
\hline Lu & & 0.51 & 0.51 & 0.42 & 0.60 & 0.38 & 0.30 \\
\hline \multicolumn{8}{|l|}{ Sc } \\
\hline $\mathrm{V}$ & 135 & 176 & 189 & & & & \\
\hline $\mathrm{Cr}$ & 3 & 5 & 8 & & & & \\
\hline \multicolumn{8}{|l|}{ Co } \\
\hline $\mathrm{Ni}$ & 7 & 9 & 7 & & & & \\
\hline $\mathrm{Y}$ & 31.5 & 29 & 30 & 22 & 38 & 24 & 17 \\
\hline $\mathrm{Nb}$ & 9.5 & 10 & 10 & & & & \\
\hline
\end{tabular}


TABLE $\|$

(Continued)

\begin{tabular}{|c|c|c|c|c|c|c|c|c|c|c|}
\hline \multirow{3}{*}{$\begin{array}{l}\text { Location } \\
\text { Sample } \\
\text { Type }\end{array}$} & \multicolumn{2}{|c|}{ VOT } & \multicolumn{2}{|c|}{ VOT } & \multicolumn{2}{|c|}{ VOT } & \multicolumn{2}{|c|}{ VOT } & \multicolumn{2}{|c|}{ VOT } \\
\hline & \multicolumn{2}{|c|}{ 11M1 } & \multicolumn{2}{|c|}{$10 \mathrm{M} 1$} & \multicolumn{2}{|c|}{$10 \mathrm{M} 2$} & \multicolumn{2}{|c|}{$12 \mathrm{M} 1$} & \multicolumn{2}{|c|}{ 11M2 } \\
\hline & \multicolumn{2}{|c|}{$e+c$} & \multicolumn{2}{|c|}{ c } & \multicolumn{2}{|c|}{$\mathrm{c}$} & \multicolumn{2}{|c|}{$\mathrm{d}$} & \multicolumn{2}{|c|}{$e+c$} \\
\hline $\mathrm{SiO}_{2}$ & \multicolumn{2}{|l|}{47.50} & \multicolumn{2}{|l|}{49.40} & \multicolumn{2}{|l|}{50.70} & \multicolumn{2}{|l|}{50.70} & 51.00 & \\
\hline $\mathrm{TiO}_{2}$ & 1.40 & & 1.03 & & 0.94 & & 0.77 & & 1.36 & \\
\hline $\mathrm{Al}_{2} \mathrm{O}_{3}$ & 15.79 & & 18.25 & & 17.90 & & 16.25 & & 16.51 & \\
\hline $\mathrm{Fe}_{2} \mathrm{O}_{3}$ & 1.94 & & 1.61 & & 1.51 & & 1.39 & & 1.96 & \\
\hline $\mathrm{FeO}$ & 9.90 & & 8.22 & & 7.73 & & 7.11 & & 9.99 & \\
\hline $\mathrm{MnO}$ & 0.17 & & 0.16 & & 0.17 & & 0.15 & & 0.19 & \\
\hline $\mathrm{MgO}$ & 5.57 & & 5.85 & & 5.79 & & 9.60 & & 4.18 & \\
\hline $\mathrm{CaO}$ & 10.62 & & 10.82 & & 10.53 & & 10.62 & & 8.80 & \\
\hline $\mathrm{Na}_{2} \mathrm{O}$ & 2.62 & & 2.97 & & 2.89 & & 2.32 & & 2.60 & \\
\hline $\mathrm{K}_{2} \mathrm{O}$ & 0.96 & & 0.61 & & 0.64 & & 0.66 & & 1.06 & \\
\hline $\mathrm{P}_{2} \mathrm{O}_{5}$ & 0.15 & & 0.10 & & 0.15 & & 0.10 & & 0.20 & \\
\hline $\mathrm{H}_{2} \mathrm{O}^{+}$ & 1.32 & & 0.37 & & 0.28 & & 0.33 & & 0.51 & \\
\hline $\mathrm{H}_{2} \mathrm{O}^{-}$ & 1.01 & & 0.28 & & 0.26 & & 0.13 & & 0.46 & \\
\hline Total & 98.95 & & 99.67 & & 99.49 & & 100.13 & & 98.82 & \\
\hline Source & INA & ICP & INA & ICP & INA & ICP & INA & ICP & INA & ICP \\
\hline $\mathrm{Rb}$ & 19.6 & & 7.7 & & 7.5 & & 9.4 & & 20.6 & \\
\hline $\mathrm{Sr}$ & 344 & & 296 & & 415 & & 457 & & 281 & \\
\hline $\mathrm{Ba}$ & 127 & & 84 & & 89 & & 115 & & 144 & \\
\hline $\mathrm{Hf}$ & 1.85 & & 1.5 & & 1.6 & & 1.4 & & 1.8 & \\
\hline $\mathrm{Zr}$ & 87 & 69 & 47 & 56 & 67 & 55 & 50 & 50 & 66 & 65 \\
\hline $\mathrm{Ta}$ & 0.31 & & 0.17 & & 0.17 & & 0.26 & & 0.23 & \\
\hline Th & 0.43 & & 0.30 & & 0.26 & & 0.56 & & 0.30 & \\
\hline $\mathrm{U}$ & 0.17 & & 0.11 & & 0.12 & & 0.20 & & 0.18 & \\
\hline Cs & 2.0 & & 0.11 & & 0.16 & & 0.22 & & 1.30 & \\
\hline $\mathrm{Sb}$ & 0.20 & & 0.11 & & 0.11 & & 0.09 & & 0.05 & \\
\hline As & & & 1.3 & & 1.2 & & & & 0.16 & \\
\hline $\mathrm{La}$ & 5.7 & 6.0 & 4.2 & 4.9 & 4.0 & 4.6 & 5.0 & 6.0 & 4.1 & 5.4 \\
\hline $\mathrm{Ce}$ & 15.0 & 15 & 8.1 & 12 & 8.3 & 12 & 12.9 & 13 & 9.0 & 14 \\
\hline $\mathrm{Nd}$ & & 11 & & 9.5 & & 9 & & 8 & & 11 \\
\hline $\mathrm{Sm}$ & 3.1 & & 2.4 & & 2.3 & & 2.1 & & 3.1 & \\
\hline $\mathrm{Eu}$ & 1.1 & 1.10 & 0.90 & 0.85 & 0.89 & 0.95 & 0.76 & 0.80 & 1.05 & 1.10 \\
\hline Gd & & & & & & & & & & \\
\hline $\mathrm{Tb}$ & 0.64 & & 0.47 & & 0.48 & & 0.38 & & 0.65 & \\
\hline Dy & & 4.2 & & 3.5 & & 3.3 & & 2.8 & & 4.6 \\
\hline Er & & 2.7 & & 2.4 & & 2.3 & & 1.8 & & 3.2 \\
\hline $\mathrm{Yb}$ & 2.5 & 2.55 & 2.2 & 2.2 & 2.2 & 2.05 & 1.5 & 1.65 & 2.8 & 2.75 \\
\hline Lu & & & & & & & & & & \\
\hline Sc & 38.2 & & 31.0 & & 31.1 & & 35.1 & & 35.3 & \\
\hline V & 294 & & 238 & & 260 & & 208 & & 370 & \\
\hline $\mathrm{Cr}$ & 54 & & 31 & & 13 & & 410 & & 6 & \\
\hline Co & 41.8 & & 34.3 & & 34.5 & & 38.3 & & 37.4 & \\
\hline $\mathrm{Ni}$ & 35 & & 39 & & 39 & & 179 & & 17 & \\
\hline $\mathrm{Y}$ & & 28 & & 25 & & 22 & & 17 & & 29 \\
\hline $\mathrm{Nb}$ & & 4.9 & & 3.1 & & 2.6 & & 4 & & 3.3 \\
\hline
\end{tabular}


TABLE \|

(Continued)

\begin{tabular}{|c|c|c|c|c|c|c|c|c|c|}
\hline $\begin{array}{l}\text { Location } \\
\text { Sample } \\
\text { Type }\end{array}$ & $\begin{array}{c}\text { VOT } \\
4294 \\
\mathrm{e}\end{array}$ & $\begin{array}{c}\text { VOT } \\
4295 \\
\mathrm{e}\end{array}$ & $\begin{array}{r}\mathrm{HA} \\
14 \mathrm{I} \\
\mathrm{a}\end{array}$ & $\begin{array}{l}\mathrm{HAZ} \\
14 \mathrm{M} 2\end{array}$ & & & $\begin{array}{c}\mathrm{HAZ} \\
14 \mathrm{M} 7 \\
\mathrm{a}\end{array}$ & $\begin{array}{r}\mathrm{H} \\
141\end{array}$ & 114 \\
\hline $\mathrm{SiO}_{2}$ & 54.57 & 56.87 & 45.20 & & 46.10 & & & 48.20 & \\
\hline $\mathrm{TiO}_{2}^{*}$ & 0.95 & 0.80 & 1.52 & & 1.49 & & & 2.06 & \\
\hline $\mathrm{Al}_{2} \dot{\mathrm{O}}_{3}$ & 15.15 & 15.71 & 16.05 & & 15.09 & & & 14.54 & \\
\hline $\mathrm{Fe}_{2} \mathrm{O}_{3}$ & 9.85 & 9.77 & 1.63 & & 1.55 & & & 1.88 & \\
\hline $\mathrm{FeO}$ & & & 8.31 & & 7.93 & & & 9.60 & \\
\hline $\mathrm{MnO}$ & 0.18 & 0.16 & 0.14 & & 0.16 & & & 0.19 & \\
\hline $\mathrm{MgO}$ & 4.39 & 3.85 & 7.26 & & 7.92 & & & 7.25 & \\
\hline $\mathrm{CaO}$ & 8.54 & 7.60 & 10.85 & & 10.59 & & & 9.05 & \\
\hline $\mathrm{Na}_{2} \mathrm{O}$ & 2.86 & 2.57 & 2.84 & & 2.88 & & & 3.82 & \\
\hline $\mathrm{K}_{2} \mathrm{O}$ & 1.75 & 2.31 & 0.21 & & 0.26 & & & 0.40 & \\
\hline $\mathrm{P}_{2} \mathrm{O}_{5}$ & 0.87 & 0.33 & 0.15 & & 0.10 & & & 0.15 & \\
\hline $\mathrm{H}_{2} \mathrm{O}^{+}$ & & & 2.06 & & 2.02 & & & 1.94 & \\
\hline $\mathrm{H}_{2} \mathrm{O}^{--}$ & & & 3.00 & & 3.16 & & & 0.28 & \\
\hline Total & 99.11 & 99.97 & 99.22 & & 99.25 & & 0.00 & 99.36 & \\
\hline Source & XRF/CP & XRF/ICP & INA & ICP & INA & ICP & INA & INA & ICP \\
\hline $\mathrm{Rb}$ & 37 & 47 & 2.4 & & 1.7 & & 2.0 & 4.4 & \\
\hline $\mathrm{Sr}$ & 395 & 395 & 318 & & 304 & & 190 & 466 & \\
\hline $\mathrm{Ba}$ & 270 & 326 & 36.7 & & 52.4 & & 17.5 & 118 & \\
\hline $\mathrm{Hf}$ & & & 2.4 & & 2.1 & & 2.0 & 3.0 & \\
\hline $\mathrm{Zr}$ & 80 & 76 & 106 & 93 & 76 & 89 & 77 & 139 & 116 \\
\hline Ta & & & 0.60 & & 0.55 & & 0.29 & 1.54 & \\
\hline Th & & & 0.68 & & 0.59 & & 0.44 & 1.74 & \\
\hline $\mathbf{U}$ & & & 0.22 & & 0.30 & & 0.20 & 0.45 & \\
\hline Cs & & & 0.29 & & 0.11 & & 0.02 & 0.07 & \\
\hline Sb & & & 0.01 & & 0.10 & & 0.07 & 0.09 & \\
\hline As & & & & & & & & 1.1 & \\
\hline $\mathrm{La}$ & 8.5 & 7.6 & 6.7 & 6.9 & 6.3 & 7.3 & 4.1 & 14.2 & 15 \\
\hline $\mathrm{Ce}$ & 18.7 & 17.1 & 16.5 & 17 & 16.6 & 17 & 11.7 & 24.7 & 32 \\
\hline $\mathrm{Nd}$ & 11.1 & 9.6 & & 12 & & 11 & & & 19 \\
\hline $\mathrm{Sm}$ & 3.4 & 3.0 & 2.9 & & 3.0 & & 2.3 & 4.1 & \\
\hline Eu & 1.0 & 0.84 & 1.12 & 1.10 & 1.23 & 1.25 & 0.78 & 1.45 & 1.55 \\
\hline $\mathrm{Gd}$ & 3,4 & 2.6 & & & & & & & \\
\hline $\mathrm{Tb}$ & & & 0.63 & & 0.59 & & 0.48 & 0.73 & \\
\hline Dy & 3.2 & 2.8 & & 4.1 & & 4.0 & & & 5.0 \\
\hline $\mathrm{Er}$ & 2.1 & 1.8 & & 3.0 & & 2.5 & & & 3.2 \\
\hline $\mathrm{Yb}$ & 2.1 & 1.7 & 2.9 & 2.55 & 2.2 & 2.40 & 1.8 & 2.8 & 2.55 \\
\hline Lu & 0.32 & 0.29 & & & & & & & \\
\hline $\mathrm{Sc}$ & & & 37.6 & & 34.2 & & 23.0 & 40.6 & \\
\hline $\mathrm{V}$ & & & 213 & & 195 & & & 297 & \\
\hline $\mathrm{Cr}$ & & & 356 & & 390 & & 39 & 115 & \\
\hline Co & & & 48.7 & & +4.8 & & 24.4 & 41.7 & \\
\hline $\mathrm{Ni}$ & & & 199 & & 204 & & 23 & 48 & \\
\hline$Y$ & & & & 27 & & 27 & & & 30 \\
\hline $\mathrm{Nb}$ & & & & 7.2 & & 7.5 & & & 20 \\
\hline
\end{tabular}


TABLE /

(Continued)

\begin{tabular}{|c|c|c|c|c|c|c|c|c|c|c|}
\hline $\begin{array}{l}\text { Location } \\
\text { Sample } \\
\text { Type }\end{array}$ & \multicolumn{2}{|c|}{$\begin{array}{l}\text { HAZ } \\
15 \mathrm{M} 6\end{array}$} & $\begin{array}{r}\mathrm{HA} \\
14 \mathrm{I} \\
\mathrm{a}\end{array}$ & & $\begin{array}{r}\mathrm{H} A \\
15 \mathrm{~N} \\
\mathrm{i}\end{array}$ & & $\begin{array}{c}\text { EFA } \\
27 \mathrm{M} 1 \\
\text { d }\end{array}$ & & $\begin{array}{c}\text { EFA } \\
29 \mathrm{M} \\
\mathrm{e}+\mathrm{d}\end{array}$ & \\
\hline $\mathrm{SiO}_{2}$ & 51.20 & & 52.50 & & 62.80 & & 46.50 & & 47.50 & \\
\hline $\mathrm{TiO}_{2}$ & 0.72 & & 0.75 & & 0.62 & & 0.85 & & 0.69 & \\
\hline $\mathrm{Al}_{2} \mathrm{O}_{3}$ & 17.05 & & 16.30 & & 16.07 & & 15.10 & & 13.65 & \\
\hline $\mathrm{Fe}_{2} \mathrm{O}_{3}$ & 1.50 & & 1.44 & & 0.70 & & 1.36 & & 1.21 & \\
\hline $\mathrm{FeO}$ & 7.65 & & 7.32 & & 3.60 & & 6.95 & & 6.19 & \\
\hline $\mathrm{MnO}$ & 0.17 & & 0.16 & & 0.11 & & 0.15 & & 0.18 & \\
\hline $\mathrm{MgO}$ & 5.45 & & 6.08 & & 1.64 & & 9.45 & & 10.30 & \\
\hline $\mathrm{CaO}$ & 10.74 & & 4.11 & & 0.73 & & 9.55 & & 7.30 & \\
\hline $\mathrm{Na}_{2} \mathrm{O}$ & 2.42 & & 6.08 & & 5.99 & & 2.47 & & 2.32 & \\
\hline $\mathrm{K}_{2} \mathrm{O}$ & 0.68 & & 0.10 & & 4.66 & & 0.70 & & 1.87 & \\
\hline $\mathrm{P}_{2} \mathrm{O}_{5}$ & 0.12 & & 0.15 & & 0.18 & & 0.10 & & 0.20 & \\
\hline $\mathrm{H}_{2} \mathrm{O}^{+}$ & 0.78 & & 3.81 & & 1.59 & & 3.40 & & 2.89 & \\
\hline $\mathrm{H}_{2} \mathrm{O}^{-}$ & 0.63 & & 0.69 & & 0.39 & & 2.71 & & 4.65 & \\
\hline Total & 99.11 & & 99.49 & & 99.08 & & 99.29 & & 98.95 & \\
\hline Source & INA & ICP & INA & ICP & INA & ICP & INA & ICP & INA & ICP \\
\hline $\mathrm{Rb}$ & 8.8 & & 1.4 & & 66.8 & & 7.7 & & 19.1 & \\
\hline $\mathrm{Sr}$ & 356 & & 158 & & 80 & & 354 & & 757 & \\
\hline $\mathrm{Ba}$ & 88 & & 6.0 & & 600 & & 54.0 & & 677 & \\
\hline $\mathrm{Hf}$ & 1.1 & & 1.24 & & 4.6 & & 1.25 & & 0.95 & \\
\hline $\mathrm{Zr}$ & 48 & 30 & 46 & 47 & 188 & 158 & 46 & 34 & 30 & 33 \\
\hline $\mathrm{Ta}$ & 0.24 & & 0.15 & & 0.35 & & 0.068 & & 0.052 & \\
\hline Th & 0.40 & & 0.27 & & 3.4 & & 0.314 & & 0.368 & \\
\hline $\mathrm{U}$ & 0.14 & & 0.11 & & 1.48 & & 0.15 & & 0.39 & \\
\hline $\mathrm{Cs}$ & 0.16 & & 0.01 & & 0.06 & & 0.068 & & 0.46 & \\
\hline $\mathrm{Sb}$ & 0.13 & & 0.10 & & 0.20 & & 0.061 & & 0.018 & \\
\hline As & & & & & 2.5 & & & & 0.68 & \\
\hline $\mathrm{La}$ & 4.6 & 5.2 & 3.9 & 4.3 & 17.6 & 16.0 & 2.34 & 2.7 & 2.92 & 3.3 \\
\hline $\mathrm{Ce}$ & 10.2 & 10.5 & 10.4 & 12.5 & 34.3 & 33 & 5.2 & 9 & 6.3 & 9 \\
\hline $\mathrm{Nd}$ & & 7.5 & & 8 & & 20 & & 6 & & 6 \\
\hline $\mathrm{Sm}$ & 2.0 & & 2.0 & & 4.5 & & 2.02 & & 1.79 & \\
\hline $\mathrm{Eu}$ & 0.86 & 0.80 & 0.75 & 0.75 & 0.98 & 1.05 & 0.90 & 0.90 & 0.73 & 0.75 \\
\hline Gd & & & & & & & & & & \\
\hline $\mathrm{Tb}$ & 0.36 & & 0.39 & & 0.65 & & 0.422 & & 0.328 & \\
\hline Dy & & 2.5 & & 2.9 & & 4.0 & & 3.0 & & 2.5 \\
\hline Er & & 1.6 & & 1.8 & & 2.8 & & 2.0 & & 1.8 \\
\hline $\mathrm{Yb}$ & 1.3 & 1.35 & 1.51 & 1.65, & 3.2 & 3.00 & 1.51 & 1.75 & 1.12 & 1.35 \\
\hline $\mathrm{Lu}$ & & & & & & & & & & \\
\hline Sc & 36.1 & & 29.7 & & 7.3 & & 38.6 & & 32.6 & \\
\hline V & 249 & & 163 & & & & 237 & & 240 & \\
\hline $\mathrm{Cr}$ & 53 & & 51 & & & & 255 & & 317 & \\
\hline Co & 35.2 & & 33.6 & & 6.1 & & 34.6 & & 44.9 & \\
\hline $\mathrm{Ni}$ & 35 & & 32 & & 5 & & 65 & & 160 & \\
\hline $\mathrm{Y}$ & & 16 & & 18 & & 28 & & 20 & & 14 \\
\hline $\mathrm{Nb}$ & & 3.7 & & 3.0 & & 5.6 & & 1.0 & & 1.6 \\
\hline
\end{tabular}


TABLE \|

(Continued)

\begin{tabular}{|c|c|c|c|c|c|c|c|c|c|c|}
\hline $\begin{array}{l}\text { Location } \\
\text { Sample } \\
\text { Type } \\
\end{array}$ & \multicolumn{2}{|c|}{$\begin{array}{c}\text { EFA } \\
31 \mathrm{M} 2\end{array}$} & $\begin{array}{c}\text { EFA } \\
31 \mathrm{M} \\
\mathrm{d}\end{array}$ & & $\begin{array}{c}E F A \\
30 M \\
d\end{array}$ & & $\begin{array}{c}\text { EFA } \\
30 \mathrm{M} \\
\mathrm{d}\end{array}$ & & $\begin{array}{c}\text { EFA } \\
27 \mathrm{M} \\
\mathrm{i}\end{array}$ & \\
\hline $\mathrm{SiO}_{2}$ & 51.70 & & 52.00 & & 53.00 & & 54.40 & & 61.80 & \\
\hline $\mathrm{TiO}_{2}^{\sim}$ & 0.74 & & 0.72 & & 0.53 & & 0.60 & & 0.80 & \\
\hline $\mathrm{Al}_{2} \mathrm{O}_{3}$ & 15.50 & & 15.35 & & 13.22 & & 15.30 & & 15.89 & \\
\hline $\mathrm{Fe}_{2} \mathrm{O}_{3}^{3}$ & 1.33 & & 1.33 & & 1.42 & & 1.35 & & 0.85 & \\
\hline $\mathrm{FeO}$ & 6.76 & & 6.76 & & 7.25 & & 6.87 & & 4.34 & \\
\hline $\mathrm{MnO}$ & 0.15 & & 0.15 & & 0.16 & & 0.15 & & 0.07 & \\
\hline $\mathrm{MgO}$ & 7.34 & & 7.37 & & 10.28 & & 7.72 & & 2.01 & \\
\hline $\mathrm{CaO}$ & 11.50 & & 11.55 & & 9.18 & & 8.97 & & 2.82 & \\
\hline $\mathrm{Na}_{2} \mathrm{O}$ & 2.35 & & 2.27 & & 1.92 & & 2.16 & & 4.50 & \\
\hline $\mathrm{K}_{2} \mathrm{O}$ & 0.38 & & 0.41 & & 0.62 & & 0.75 & & $5.60)$ & \\
\hline $\mathrm{P}_{2} \mathrm{O}_{5}$ & 0.15 & & 0.15 & & 0.05 & & 0.10 & & 0.30 & \\
\hline $\mathrm{H}_{2} \mathrm{O}^{+}$ & 0.30 & & 0.09 & & 0.32 & & 0.27 & & 0.41 & \\
\hline $\mathrm{H}_{2} \mathrm{O}^{-}$ & 0.12 & & 0.10 & & 0.12 & & 0.10 & & 0.18 & \\
\hline Total & 98.32 & & 98.25 & & 98.07 & & 98.74 & & 99.57 & \\
\hline Source & INA & ICP & INA & ICP & INA & ICP & INA & ICP & INA & ICP \\
\hline $\mathrm{Rb}$ & 4.8 & & 5.6 & & 10.2 & & 11.5 & & 96 & \\
\hline $\mathrm{Sr}$ & 395 & & 402 & & 352 & & 351 & & 257 & \\
\hline $\mathrm{Ba}$ & 82.4 & & 81.3 & & 178 & & 200 & & 818 & \\
\hline $\mathrm{Hf}$ & 1.03 & & 1.12 & & 0.98 & & 1.16 & & 4.2 & \\
\hline $\mathrm{Zr}$ & 38 & 34 & 37 & 35 & 43 & 34 & 47 & 39 & 171 & 90 \\
\hline Ta & 0.068 & & 0.1075 & & 0.040 & & 0.052 & & 0.21 & \\
\hline Th & 0.418 & & 0.438 & & 0.680 & & 0.777 & & 4.1 & \\
\hline $\mathrm{U}$ & 0.14 & & 0.22 & & 0.23 & & 0.13 & & 2.2 & \\
\hline $\mathrm{Cs}$ & 0.22 & & 0.22 & & 0.30 & & 0.34 & & 0.68 & \\
\hline $\mathrm{Sb}$ & 0.037 & & 0.058 & & 0.044 & & 0.050 & & 0.10 & \\
\hline As & 1.04 & & 1.41 & & 1.00 & & 1.31 & & 0.8 & \\
\hline $\mathrm{La}$ & 3.64 & 3.7 & 3.43 & 3.9 & 3.57 & 4.0 & 3.95 & 4.7 & 12.6 & 14.3 \\
\hline $\mathrm{Ce}$ & 10.3 & 9 & 10.7 & 10 & 5.8 & 9.5 & 7.7 & 9.5 & 27.3 & 31 \\
\hline $\mathrm{Nd}$ & & 7 & & 0.5 & & 5.5 & & 6.5 & & 20 \\
\hline $\mathrm{Sm}$ & 1.84 & & 1.88 & & 1.47 & & 1.62 & & 3.9 & \\
\hline $\mathrm{Eu}$ & 0.75 & 0.70 & 0.78 & 0.80 & 0.52 & 0.55 & 0.59 & 0.60 & 0.98 & 1.05 \\
\hline Gd & & & & & & & & & & \\
\hline $\mathrm{Th}$ & 0.339 & & 0.355 & & 0.266 & & 0.298 & & 0.53 & \\
\hline Dy & & 2.5 & & 25 & & 2.2 & & 2.3 & & 3.3 \\
\hline $\mathrm{Er}$ & & 1.6 & & 1.7 & & 1.5 & & 1.7 & & 2.1 \\
\hline $\mathrm{Yb}$ & 1.36 & 1.55 & 1.46 & 1.50 & 1.15 & 1.40 & 1.24 & 1.45 & 2.5 & 1.90 \\
\hline Lu & & & & & & & & & & \\
\hline $\mathrm{Sc}$ & 33.8 & & 35.7 & & 32.3 & & 27.7 & & 8.8 & \\
\hline V & 264 & & 252 & & 214 & & 218 & & 140 & \\
\hline $\mathrm{Cr}$ & 209 & & 236 & & 388 & & 178 & & 42 & \\
\hline $\mathrm{Co}$ & 33.7 & & 34.9 & & 44.7 & & 34.8 & & 6.7 & \\
\hline $\mathrm{Ni}$ & 72 & & 74 & & 188 & & 121 & & 17 & \\
\hline Y & & 16 & & 16 & & 14 & & 15 & & 21 \\
\hline $\mathrm{Nb}$ & & 1.6 & & 1.7 & & 1.0 & & 1.2 & & 3.7 \\
\hline
\end{tabular}


TABLE II

(Continued)

\begin{tabular}{|c|c|c|c|c|c|c|c|c|c|}
\hline Location & \multicolumn{2}{|c|}{ EFA } & EFA & EFA & EFA & \multicolumn{2}{|c|}{$\mathrm{EFA}$} & EFA & ERR \\
\hline Sample & \multicolumn{2}{|c|}{ 27M1 } & $27 \mathrm{M} 4$ & 29M3 & 28M1 & \multicolumn{2}{|c|}{$26 \mathrm{M} 6$} & $26 \mathrm{M} 7$ & $22 \mathrm{M} 1$ \\
\hline Type & \multicolumn{2}{|c|}{ i } & $\mathbf{i}$ & i & i & \multicolumn{2}{|c|}{ h } & $\mathrm{h}$ & $\mathrm{d}$ \\
\hline $\mathrm{SiO}_{2}$ & \multicolumn{2}{|l|}{63.00} & 63.40 & 64.00 & 64.80 & \multicolumn{2}{|l|}{65.70} & 66.30 & 49.00 \\
\hline $\mathrm{TiO}_{2}$ & \multicolumn{2}{|l|}{0.43} & 0.50 & 0.50 & 0.65 & \multicolumn{2}{|l|}{0.55} & 0.61 & 0.79 \\
\hline $\mathrm{Al}_{2} \mathrm{O}_{3}$ & \multicolumn{2}{|l|}{14.93} & 15.09 & 15.08 & 14.95 & \multicolumn{2}{|l|}{14.36} & 14.16 & 14.73 \\
\hline $\mathrm{Fe}_{2} \mathrm{O}_{3}$ & \multicolumn{2}{|l|}{0.65} & 0.68 & 0.66 & 0.60 & \multicolumn{2}{|l|}{0.71} & 0.69 & 1.54 \\
\hline $\mathrm{FeO}$ & \multicolumn{2}{|l|}{3.30} & 3.46 & 3.38 & 3.08 & \multicolumn{2}{|l|}{3.63} & 3.53 & 7.88 \\
\hline $\mathrm{MnO}$ & \multicolumn{2}{|l|}{0.12} & 0.12 & 0.12 & 0.09 & \multicolumn{2}{|l|}{0.12} & 0.12 & 0.17 \\
\hline $\mathrm{MgO}$ & \multicolumn{2}{|l|}{1.00} & 0.85 & 0.81 & 2.47 & \multicolumn{2}{|l|}{1.05} & 1.01 & 6.51 \\
\hline $\mathrm{CaO}$ & \multicolumn{2}{|l|}{2.33} & 2.32 & 2.21 & 0.94 & 2.58 & & 2.37 & 12.94 \\
\hline $\mathrm{Na}_{2} \mathrm{O}$ & 4.64 & & 4.55 & 4.51 & 3.47 & 4.83 & & 4.76 & 2.08 \\
\hline $\mathrm{K}_{2} \mathrm{O}$ & 4.96 & & 4.92 & 4.79 & 6.25 & 3.70 & & 3.62 & 0.81 \\
\hline $\mathrm{P}_{2} \mathrm{O}_{5}$ & 0.15 & & 0.15 & 0.15 & 0.40 & 0.15 & & 0.20 & 0.20 \\
\hline $\mathrm{H}_{2} \mathrm{O}^{+}$ & 2.73 & & 2.65 & 2.26 & 1.54 & 2.16 & & 1.91 & 1.95 \\
\hline $\mathrm{H}_{2} \mathrm{O}^{-}$ & 1.59 & & 0.44 & 0.99 & 0.61 & 0.33 & & 0.07 & 0.68 \\
\hline Total & 99.83 & & 99.13 & 99.46 & 99.85 & 99.87 & & 99.35 & 99.28 \\
\hline Source & INA & ICP & $\mathrm{AA} / \mathrm{ICP}$ & $\mathrm{AA} / \mathrm{ICP}$ & $\mathrm{AA} / \mathrm{ICP}$ & INA & ICP & AA/ICP & $\mathrm{AA} / \mathrm{ICP}$ \\
\hline $\mathbf{R b}$ & 57.6 & & 97 & 65 & 114 & 65.4 & & 70 & 13 \\
\hline $\mathrm{Sr}$ & 297 & & 272 & 256 & 153 & 228 & & 272 & 405 \\
\hline $\mathrm{Ba}$ & 912 & & 825 & 819 & 1045 & 1017 & & 950 & 108 \\
\hline $\mathrm{Hf}$ & 6.0 & & & & & 6.1 & & & \\
\hline $\mathrm{Zr}$ & 235 & 205 & 214 & 218 & 150 & 204 & 210 & 210 & 54 \\
\hline $\mathrm{Ta}$ & 0.34 & & & & & 0.30 & & & \\
\hline $\mathrm{Th}$ & 7.4 & & & & & 5.1 & & & \\
\hline $\mathbf{U}$ & 2.7 & & & & & 1.85 & & & \\
\hline Cs & 1.78 & & & & & 2.2 & & & \\
\hline $\mathrm{Sb}$ & 0.23 & & & & & 0.23 & & & \\
\hline As & 3.7 & & & & & 6.1 & & & \\
\hline $\mathrm{La}$ & 23.8 & 24.5 & 25 & 25 & 15.2 & 23.6 & 25 & 25 & 4.9 \\
\hline $\mathrm{Ce}$ & 48.1 & 50 & 50 & 51 & 34 & 44.2 & 51 & 50 & 12 \\
\hline $\mathrm{Nd}$ & & 25 & 24 & 25 & 19 & & 28 & 28 & 8 \\
\hline $\mathrm{Sm}$ & 5.0 & & & & & 6.1 & & & \\
\hline Eu & 1.00 & 1.10 & 1.10 & 1.10 & 0.95 & 1.3 & 1.30 & 1.45 & 0.90 \\
\hline $\mathrm{Gd}$ & & & & & & & & & \\
\hline $\mathrm{Tb}$ & 0.62 & & & & & 0.84 & & & \\
\hline Dy & & 4.1 & 4.1 & 4.5 & 3.4 & & 5.3 & 5.6 & 2.5 \\
\hline $\mathrm{Er}$ & & 2.8 & 3.0 & 3.0 & 2.3 & & 3.7 & 4.0 & 1.7 \\
\hline $\mathrm{Yb}$ & 3.3 & 2.85 & 3.00 & 3.05 & 2.20 & 4.2 & 3.90 & 4.05 & 1.60 \\
\hline $\mathrm{Lu}$ & & & & & & & & & \\
\hline Sc & 8.2 & & & & & 10.3 & & & \\
\hline V & 40 & & 49 & 50 & 83 & 45 & & 52 & 306 \\
\hline $\mathrm{Cr}$ & 7 & & 2 & 3 & 10 & 2 & & 2 & 298 \\
\hline Co & 7.7 & & 7 & 7 & 7 & 6.3 & & 5 & 38 \\
\hline $\mathrm{Ni}$ & 1.9 & & 1 & 2 & 10 & 2 & & 1 & 101 \\
\hline $\mathrm{Y}$ & & 27 & 28 & 29 & 22.5 & & 37 & 38 & 17 \\
\hline $\mathrm{Nb}$ & & 5.1 & 5.3 & 6.2 & 3.7 & & 4.5 & 4.8 & 1.3 \\
\hline
\end{tabular}


TABLE II

(Continued)

\begin{tabular}{|c|c|c|c|c|c|c|c|c|c|c|}
\hline $\begin{array}{l}\text { Location } \\
\text { Sample } \\
\text { Type }\end{array}$ & $\begin{array}{r}\mathrm{ER} \\
25 \mathrm{~N} \\
\mathrm{C}\end{array}$ & & $\begin{array}{r}\text { ER } \\
25 \mathrm{~N} \\
\mathrm{C}\end{array}$ & & $\begin{array}{c}\text { ERR } \\
24 M 6 \\
b\end{array}$ & $\begin{array}{c}\text { ERR } \\
24 M 4 \\
\mathrm{~d}\end{array}$ & $\begin{array}{r}\text { ER } \\
241 \\
\mathrm{~h}\end{array}$ & & $\begin{array}{l}\text { FU } \\
19 \mathrm{~N} \\
\mathrm{C}+\end{array}$ & \\
\hline $\mathrm{SiO}_{2}$ & 50.30 & & & & 51.30 & 52.50 & 65.00 & & 50.00 & \\
\hline $\mathrm{TiO}_{2}$ & 0.94 & & & & 0.79 & 0.60 & 0.62 & & 1.00 & \\
\hline $\mathrm{Al}_{2} \mathrm{O}_{3}$ & 16.84 & & & & 18.13 & 14.80 & 14.60 & & 14.90 & \\
\hline $\mathrm{Fe}_{2} \mathrm{O}_{3}$ & 1.85 & & & & 1.50 & 1.55 & 0.98 & & 1.21 & \\
\hline $\mathrm{FeO}$ & 9.45 & & & & 7.66 & 7.90 & 5.00 & & 6.16 & \\
\hline $\mathrm{MnO}$ & 0.16 & & & & 0.16 & 0.14 & 0.14 & & 0.24 & \\
\hline $\mathrm{MgO}$ & 5.91 & & & & 4.31 & 7.21 & 1.11 & & 9.62 & \\
\hline $\mathrm{CaO}$ & 10.55 & & & & 10.58 & 10.33 & 3.60 & & 10.46 & \\
\hline $\mathrm{Na}_{2} \mathrm{O}$ & 2.47 & & & & 2.85 & 2.42 & 4.19 & & 2.29 & \\
\hline $\mathrm{K}_{2} \mathrm{O}$ & 0.62 & & & & 0.85 & 0.83 & 2.96 & & 0.83 & \\
\hline $\mathrm{P}_{2} \mathrm{O}_{5}$ & 0.15 & & & & 0.10 & 0.10 & 0.25 & & 0.25 & \\
\hline $\mathrm{H}_{2}^{-} \mathrm{O}^{+}$ & -0.14 & & & & 0.72 & 0.12 & 0.92 & & 1.12 & \\
\hline $\mathrm{H}_{2}^{2} \mathrm{O}^{-}$ & 0.13 & & & & 0.76 & 0.23 & 0.27 & & 0.61 & \\
\hline Total & 99.23 & & 0.00 & & 99.71 & 98.73 & 99.64 & & 98.69 & \\
\hline Source & INA & ICP & INA & ICP & $\mathrm{AA} / \mathrm{ICP}$ & INA & INA & ICP & INA & ICP \\
\hline $\mathrm{Rb}$ & 10.8 & & 7.7 & & 10 & 12.8 & 49.4 & & 12.2 & \\
\hline $\mathrm{Sr}$ & 606 & & $620)$ & & 410 & 424 & 244 & & 789 & \\
\hline $\mathrm{Ba}$ & 168 & & 152 & & 283 & 218 & 626 & & 106 & \\
\hline $\mathrm{Hf}$ & 1.4 & & 1.3 & & & 1.4 & 4.7 & & 1.8 & \\
\hline $\mathrm{Zr}$ & 52 & 42 & 49 & 42 & 43 & 54 & 176 & 153 & 65 & 68 \\
\hline $\mathrm{Ta}$ & 0.13 & & 0.094 & & & 0.065 & 0.25 & & 0.46 & \\
\hline Th & 0.71 & & 0.58 & & & 0.55 & 2.0 & & 0.85 & \\
\hline $\mathbf{U}$ & 0.25 & & 0.26 & & & 0.27 & 1.18 & & 0.32 & \\
\hline $\mathrm{Cs}$ & 0.35 & & 0.19 & & & 0.55 & 2.2 & & 0.36 & \\
\hline Sb & 0.08 & & 0.08 & & & 0.12 & 0.47 & & 0.10 & \\
\hline As & 1.5 & & & & & 1.9 & 6.9 & & 0.9 & \\
\hline La & 5.7 & 5.8 & 5.4 & 3.8 & 6.4 & 3.7 & 11.8 & 12.5 & 8.6 & 9.2 \\
\hline $\mathrm{Ce}$ & 128 & 15 & 12.9 & 10 & 14 & 6.9 & 26.1 & 28 & 16.2 & 19.5 \\
\hline $\mathrm{Nd}$ & & 10 & & 7 & 12 & & & 19 & & 12 \\
\hline $\mathrm{Sm}$ & 2.8 & & 2.8 & & & 2.0 & 4.6 & & 2.8 & \\
\hline $\mathrm{Eu}$ & 0.95 & 0.95 & 0.93 & 0.70 & 1.30 & 0.70 & 1.14 & 1.25 & 0.97 & 1.00 \\
\hline $\mathrm{Gd}$ & & & & & & & & & & \\
\hline $\mathrm{Th}$ & 0.51 & & 0.47 & & & 0.40 & 0.84 & & 0.45 & \\
\hline Dy & & 3.2 & & 2.5 & 4.4 & & & 5.8 & & 3.1 \\
\hline $\mathrm{Er}$ & & 2.1 & & 1.8 & 2.7 & & & 3.8 & & 2.0 \\
\hline $\mathrm{Yb}$ & 2.2 & 1.90 & 1.9 & 1.60 & 2.45 & 2.1 & 4.3 & 3.90 & 1.7 & 1.60 \\
\hline Lu & & & & & & & & & & \\
\hline $\mathrm{Sc}$ & 37.4 & & 35.4 & & & 37.7 & 14.1 & & 32.9 & \\
\hline$v$ & 368 & & & & 368 & 255 & 35 & & 231 & \\
\hline $\mathrm{Cr}$ & 40 & & 42 & & 58 & 256 & & & 943 & \\
\hline Co & 40.2 & & 39.1 & & 24 & 37.4 & 9.3 & & 39.2 & \\
\hline $\mathrm{Ni}$ & 33 & & 33 & & 24 & 75 & 0.9 & & 324 & \\
\hline$Y$ & & 20 & & 17 & 33 & & & 38 & & 18.5 \\
\hline $\mathrm{Nb}$ & & 1.2 & & 1.3 & 1.3 & & & 3.4 & & 6.3 \\
\hline
\end{tabular}


TABLE I

(Continued)

\begin{tabular}{|c|c|c|c|c|c|c|c|c|c|c|}
\hline $\begin{array}{l}\text { Location } \\
\text { Sample } \\
\text { Type }\end{array}$ & \multicolumn{2}{|c|}{ FUT } & $\begin{array}{c}\text { FU' } \\
20 \mathrm{M} \\
\text { b }\end{array}$ & & $\begin{array}{c}\mathrm{FU} \\
21 \mathrm{~N} \\
\mathrm{e}+\end{array}$ & & & T1 & $\begin{array}{r}\text { FU } \\
17 \mathrm{~N} \\
\mathrm{e}\end{array}$ & \\
\hline $\mathrm{SiO}_{2}$ & 50.20 & & 50.50 & & 50.75 & & 53.45 & . & 54.10 & \\
\hline $\mathrm{TiO}_{2}$ & 0.50 & & 0.86 & & 0.64 & & 0.82 & & 0.68 & \\
\hline $\mathrm{Al}_{2} \mathrm{O}_{3}$ & 13.16 & & 18.30 & & 14.17 & & 14.72 & & 13.97 & \\
\hline $\mathrm{Fe}_{2} \mathrm{O}_{3}$ & 1.44 & & 1.40 & & 1.45 & & 1.44 & & 1.34 & \\
\hline $\mathrm{FeO}$ & 7.37 & & 7.14 & & 7.39 & & 7.37 & & 6.85 & \\
\hline $\mathrm{MnO}$ & 0.16 & & 0.16 & & 0.16 & & 0.18 & & 0.17 & \\
\hline $\mathrm{MgO}$ & 10.66 & & 4.52 & & 8.73 & & 4.57 & & 5.18 & \\
\hline $\mathrm{CaO}$ & 11.58 & & 11.48 & & 11.70 & & 6.71 & & 7.67 & \\
\hline $\mathrm{Na}_{2} \mathrm{O}$ & 1.73 & & 2.57 & & 1.92 & & 3.41 & & 3.19 & \\
\hline $\mathrm{K}_{2} \mathrm{O}$ & 0.32 & & 0.46 & & 0.96 & & 1.84 & & 1.64 & \\
\hline $\mathrm{P}_{2} \mathrm{O}_{5}$ & 0.08 & & 0.10 & & 0.30 & & 0.30 & & 0.30 & \\
\hline $\mathrm{H}_{2} \mathrm{O}^{+}$ & 1.13 & & 1.59 & & 0.50 & & 1.99 & & 1.86 & \\
\hline $\mathrm{H}_{2} \mathrm{O}^{-}$ & 0.43 & & 0.22 & & 0.53 & & 2.23 & & 1.34 & \\
\hline Total & 98.76 & & 99.30 & & 99.20 & & 99.03 & & 98.29 & \\
\hline Source & INA & ICP & INA & ICP & INA & ICP & INA & ICP & INA & ICP \\
\hline $\mathrm{Rb}$ & 4.8 & & 5.8 & & 13.7 & & 19.4 & & 28.8 & \\
\hline $\mathrm{Sr}$ & 321 & & 336 & & 618 & & 547 & & 437 & \\
\hline $\mathrm{Ba}$ & 52.7 & & 110 & & 157 & & 339 & & 277 & \\
\hline $\mathrm{Hf}$ & 1.0 & & 1.2 & & 2.1 & & 3.1 & & 2.5 & \\
\hline $\mathrm{Zr}$ & 28 & 30 & 52 & 37 & 87 & 84 & 135 & 109. & 86 & 87 \\
\hline $\mathrm{Ta}$ & 0.043 & & 0.021 & & 0.091 & & 0.28 & & 0.22 & \\
\hline Th & 0.12 & & 0.29 & & 1.09 & & 2.2 & & 1.76 & \\
\hline U & 0.09 & & 0.13 & & 0.80 & & 0.74 & & 0.79 & \\
\hline Cs & 0.25 & & 0.17 & & 0.24 & & 0.48 & & 0.84 & \\
\hline $\mathrm{Sb}$ & 0.06 & & 0.04 & & 0.04 & & 0.14 & & 0.11 & \\
\hline As & 0.6 & & 0.6 & & & & 1.1 & & 1.9 & \\
\hline $\mathrm{La}$ & 1.4 & 1.7 & 2.5 & 3.3 & 16.7 & 17.5 & 16.5 & 16 & 12.7 & 13.4 \\
\hline $\mathrm{Ce}$ & 3.9 & 4 & 6.1 & 9 & 44.3 & 45 & 28.0 & 34 & 22.8 & 30 \\
\hline Nd & & 3 & & 8 & & 32 & & 20 & & 17 \\
\hline $\mathrm{Sm}$ & 1.1 & & 2.3 & & 6.7 & & 4.4 & & 4.1 & \\
\hline Eu & 0.48 & 0.50 & 0.92 & 0.90 & 1.89 & 2.00 & 1.3 & 1.40 & 1.12 & 1.20 \\
\hline $\begin{array}{l}\mathrm{Gd} \\
\mathrm{Tb}\end{array}$ & 0.29 & & 0.44 & & 0.65 & & 0.69 & & 0.61 & · \\
\hline Dy & 0.27 & 1.9 & & 2.9 & & 3.6 & & 4.2 & & 3.8 \\
\hline $\mathrm{Er}$ & & 1.4 & & 2.0 & & 2.2 & & 2.8 & & 2.6 \\
\hline $\mathrm{Yb}$ & 1.6 & 1.35 & 1.8 & 1.75 & 1.58 & 1.80 & 3.1 & 2.7 & 2.6 & 2.25 \\
\hline $\mathrm{Lu}$ & & & & & & & & & & \\
\hline Sc & 39.7 & & 32.9 & & 41.3 & & 25.5 & & 28.4 & \\
\hline V & 216 & & 279 & & 361 & & 225 & & 195 & \\
\hline $\mathrm{Cr}$ & 574 & & 22 & & 400 & & 59 & & 139 & \\
\hline Co & 47.0 & & 30 & & 39.9 & & 28.1 & & 29.3 & \\
\hline $\mathrm{Ni}$ & 146 & & 32 & & 100 & & 30 & & 46 & \\
\hline Y & & 14 & & 19 & & 22 & & 28 & & 25 \\
\hline $\mathrm{Nb}$ & & 1.5 & & 1.0 & & 2.3 & & 5.2 & & 3.4 \\
\hline
\end{tabular}


TABLE /

(Continued)

\begin{tabular}{|c|c|c|c|c|c|c|c|c|c|c|}
\hline \multirow{3}{*}{$\begin{array}{l}\text { Location } \\
\text { Sample } \\
\text { Type }\end{array}$} & \multicolumn{2}{|c|}{ FUT } & FUT & \multicolumn{2}{|c|}{ FUT } & ANA & ANA & ANA & ANA & ANA \\
\hline & \multicolumn{2}{|c|}{$20 \mathrm{M} 6$} & $20 \mathrm{M} 1$ & \multicolumn{2}{|c|}{$20 \mathrm{M} 3$} & 4.311 & 4312 & 4313 & 4314 & 4315 \\
\hline & \multicolumn{2}{|c|}{$\mathrm{c}$} & c & \multicolumn{2}{|c|}{$c$} & $\mathrm{~h}$ & $\mathrm{~h}$ & $\mathrm{~h}$ & h & $\mathrm{h}$ \\
\hline $\mathrm{SiO}_{2}$ & \multicolumn{2}{|l|}{54.70} & 55.10 & \multicolumn{2}{|l|}{55.70} & 60.10 & 59.40 & 60.35 & 59.45 & 58.70 \\
\hline $\mathrm{TiO}_{2}$ & \multicolumn{2}{|l|}{1.09} & 1.23 & \multicolumn{2}{|l|}{0.95} & 0.85 & 0.89 & 0.87 & 0.83 & 0.83 \\
\hline $\mathrm{Al}_{2} \mathrm{O}_{3}$ & \multicolumn{2}{|l|}{19.46} & 17.60 & \multicolumn{2}{|l|}{17.30} & 14.35 & 15.16 & 14.70 & 13.95 & $1+.09$ \\
\hline $\mathrm{Fe}_{2} \mathrm{O}_{3}$ & \multicolumn{2}{|l|}{1.09} & 1.17 & \multicolumn{2}{|l|}{1.13} & 9.70 & 9.41 & 9.17 & 9.85 & 9.78 \\
\hline $\mathrm{FeO}$ & \multicolumn{2}{|l|}{5.58} & 5.95 & \multicolumn{2}{|l|}{5.77} & & & & & \\
\hline $\mathrm{MnO}$ & \multicolumn{2}{|l|}{0.13} & 0.14 & \multicolumn{2}{|l|}{0.14} & 0.20 & 0.19 & 0.17 & 0.21 & 0.21 \\
\hline $\mathrm{MgO}$ & \multicolumn{2}{|l|}{2.98} & 4.79 & 4.56 & & 2.04 & 1.92 & 1.93 & 1.99 & 1.99 \\
\hline $\mathrm{CaO}$ & 8.68 & & 8.32 & 8.30 & & 5.11 & 5.10 & 5.14 & 5.10 & 5.04 \\
\hline $\mathrm{Na}_{2} \mathrm{O}$ & 3.79 & & 3.87 & 3.38 & & 4.23 & 4.73 & 4.47 & 4.17 & 4.34 \\
\hline $\mathrm{K}_{2} \mathrm{O}$ & 0.80 & & 0.56 & 0.79 & & 2.28 & 2.44 & 2.35 & 2.37 & 2.04 \\
\hline $\mathrm{P}_{2} \mathrm{O}_{3}$ & 0.15 & & 0.30 & 0.15 & & 0.42 & 0.45 & 0.42 & 0.41 & 0.43 \\
\hline $\mathrm{H}_{2} \mathrm{O}^{+}$ & 0.10 & & 0.09 & 0.50 & & 0.87 & 0.15 & 0.07 & 1.47 & 1.62 \\
\hline $\mathrm{H}_{2} \mathrm{O}^{-}$ & 0.08 & & 0.06 & 0.14 & & & & & & \\
\hline Total & 98.63 & & 99.18 & 98.81 & & 100.15 & 99.84 & 99.64 & 99.80 & 99.07 \\
\hline Source & INA & ICP & $\mathrm{AA} / \mathrm{ICP}$ & INA & ICP & ICP & ICP & ICP & ICP & ICP \\
\hline $\mathrm{Rb}$ & 10.1 & & 7 & 11.6 & & 25 & 30 & 42 & 30 & 24 \\
\hline $\mathrm{Sr}$ & 329 & & 249 & 363 & & 408 & 420 & 413 & 398 & 400 \\
\hline $\mathrm{Ba}$ & 147 & & 68 & 145 & & 270 & 284 & 270 & 273 & 257 \\
\hline $\mathrm{Hf}$ & 2.4 & & & 2.2 & & & & & & \\
\hline $\mathrm{Zr}$ & 92 & 90 & 142 & 86 & 86 & 107 & 112 & 108 & 102 & 105 \\
\hline $\mathrm{Ta}$ & 0.13 & & & 0.13 & & & & & & \\
\hline Th & 0.71 & & & 0.55 & & & & & & \\
\hline $\mathrm{U}$ & 0.29 & & & 0.30 & & & & & & \\
\hline $\mathrm{Cs}$ & 0.32 & & & 0.38 & & & & & & \\
\hline $\mathrm{Sb}$ & 0.06 & & & 0.10 & & & & & & \\
\hline As & 1.3 & & & 1.7 & & & & & & \\
\hline $\mathrm{La}$ & 5.9 & 6.7 & 7.5 & 5.5 & 6.20 & 10.85 & 12.45 & 11.35 & 12.10 & 11.35 \\
\hline $\mathrm{Ce}$ & 15.0 & 17 & 21 & 16.7 & 17 & & & & & \\
\hline $\mathrm{Nd}$ & & 13 & 15 & & 12 & 20 & 21 & 20 & 20 & 20 \\
\hline $\mathrm{Sm}$ & 3.6 & & & 3.5 & & & & & & \\
\hline Eu & 1.21 & 1.30 & 1.30 & 1.2 & 1.15 & 1.55 & 1.65 & 1.50 & 1.70 & 1.50 \\
\hline Gd & & & & & & & & & & \\
\hline Tb & 0.64 & & & 0.62 & & & & & & \\
\hline Dy & & 4.2 & 4.8 & & 3.9 & 5.5 & 6.1 & 5.4 & 5.7 & 5.5 \\
\hline Er & & 2.7 & 3.4 & & 2.7 & 3.8 & 4.0 & 3.6 & 3.7 & 3.7 \\
\hline $\mathrm{Yb}$ & 3.1 & 2.60 & 3.10 & 2.7 & 2.55 & 3.55 & 3.80 & 3.30 & 3.50 & 3.50 \\
\hline Lu & & & & & & & & & & \\
\hline Sc & 22.0 & & & 29.9 & & 19.0 & 19.0 & 19.5 & 19.0 & 18.5 \\
\hline V & 206 & & 240 & 218 & & 150 & 150 & 160 & 157 & 150 \\
\hline $\mathrm{Cr}$ & 15 & & 60 & 89 & & 2 & 3 & 5 & 3 & 3 \\
\hline Co & 18 & & 23 & 22.8 & & 20 & 19 & 19 & 20 & 19 \\
\hline $\mathrm{Ni}$ & 16 & & 26 & 50 & & 4 & 5 & 5 & 5 & 5 \\
\hline Y & & 28 & 32 & & 27 & $3 n$ & 39 & 36 & 36 & 36 \\
\hline $\mathrm{Nb}$ & & 2.1 & 2.6 & & 2.3 & 1.75 & 1.95 & 1.95 & 1.45 & 0.85 \\
\hline
\end{tabular}


TABLE II

(Continued)

\begin{tabular}{|c|c|c|c|c|c|c|c|c|c|}
\hline $\begin{array}{l}\text { Location } \\
\text { Sample } \\
\text { Type }\end{array}$ & $\begin{array}{c}\text { ANA } \\
4316 \\
h\end{array}$ & $\begin{array}{c}\text { ANA } \\
4318 \\
\mathrm{~h}\end{array}$ & $\begin{array}{c}\text { ANA } \\
43110 \\
\mathrm{~h}\end{array}$ & $\begin{array}{c}\text { ANA } \\
43112 \\
\mathrm{~h}\end{array}$ & $\begin{array}{c}\text { ANA } \\
4421 \\
b\end{array}$ & $\begin{array}{c}\text { ANA } \\
4422 \\
\text { b }\end{array}$ & $\begin{array}{c}\text { ANA } \\
4423 \\
b\end{array}$ & $\begin{array}{c}\text { ANA } \\
4424 \\
\text { c }\end{array}$ & $\begin{array}{c}\text { ANA } \\
4531 \\
\text { h }\end{array}$ \\
\hline $\mathrm{SiO}_{2}$ & 58.65 & 58.60 & 58.60 & 58.85 & 48.60 & 48.80 & 48.80 & 51.00 & 60.15 \\
\hline $\mathrm{TiO}_{2}$ & 0.83 & 0.82 & 0.81 & 0.82 & 0.70 & 0.70 & 0.71 & 1.12 & 0.76 \\
\hline $\mathrm{Al}_{2} \mathrm{O}_{3}$ & 13.95 & 13.86 & 13.90 & 14.03 & 17.10 & 17.05 & 17.20 & 14.50 & 14.20 \\
\hline $\begin{array}{l}\mathrm{Fe}_{2} \mathrm{O}_{3} \\
\mathrm{FeO}\end{array}$ & 9.67 & 9.60 & 9.65 & 9.70 & 11.70 & 11.71 & 11.90 & 14.55 & 8.79 \\
\hline $\mathrm{MnO}$ & 0.21 & 0.21 & 0.21 & 0.21 & 0.19 & 0.19 & 0.20 & 0.24 & 0.20 \\
\hline $\mathrm{MgO}$ & 1.94 & 1.95 & 1.93 & 1.95 & 7.13 & 6.90 & 6.98 & 5.22 & 1.90 \\
\hline $\mathrm{CaO}$ & 5.03 & 4.96 & 5.00 & 4.98 & 11.40 & 11.35 & 11.52 & 9.85 & 4.73 \\
\hline $\mathrm{Na}_{2} \mathrm{O}$ & 4.30 & 4.40 & 4.33 & 4.27 & 2.45 & 2.39 & 2.43 & 2.80 & 4.36 \\
\hline $\mathrm{K}_{2} \mathrm{O}$ & 2.15 & 2.10 & 2.05 & 2.17 & 0.23 & 0.21 & 0.21 & 0.32 & 2.34 \\
\hline $\mathrm{P}_{2} \mathrm{O}_{5}$ & 0.40 & 0.41 & 0.40 & 0.40 & 0.12 & 0.12 & 0.12 & 0.17 & 0.41 \\
\hline $\begin{array}{l}\mathrm{H}_{2} \mathrm{O}^{+} \\
\mathrm{H}_{2} \mathrm{O}^{-}\end{array}$ & 1.95 & 3.40 & 2.73 & 2.30 & -0.27 & -0.35 & -0.31 & -0.20 & 1.91 \\
\hline Total & 99.08 & 100.31 & 99.61 & 99.68 & 99.35 & 99.07 & 99.76 & 99.57 & 99.75 \\
\hline Source & ICP & ICP & ICP & ICP & ICP & ICP & ICP & ICP & ICP \\
\hline $\mathrm{Rb}$ & 30 & 32 & 31 & 45 & 4 & 4 & 4 & 4 & 31 \\
\hline $\mathrm{Sr}$ & 397 & 390 & 396 & 398 & 390 & 410 & 398 & 402 & 382 \\
\hline $\begin{array}{l}\mathrm{Ba} \\
\mathrm{Hf}\end{array}$ & 260 & 260 & 260 & 264 & 41 & 42 & 41 & 59 & 273 \\
\hline $\begin{array}{l}\mathrm{Zr} \\
\mathrm{Ta} \\
\mathrm{Th} \\
\mathrm{U} \\
\mathrm{Cs} \\
\mathrm{Sb} \\
\mathrm{As}\end{array}$ & 104 & 102 & 102 & 102 & 22 & 23 & 23 & 34 & 116 \\
\hline $\begin{array}{l}\mathrm{La} \\
\mathrm{Ce}\end{array}$ & 10.85 & 10.70 & 10.70 & 11.25 & 2.45 & 2.40 & 2.45 & 3.70 & 11.95 \\
\hline $\begin{array}{l}\mathrm{Nd} \\
\mathrm{Sm}\end{array}$ & 19 & 20 & 19 & 20 & 6 & 6 & 6 & 9 & 20 \\
\hline $\begin{array}{l}\mathrm{Eu} \\
\mathrm{Gd} \\
\mathrm{Tb}\end{array}$ & 1.45 & 1.55 & 1.45 & 1.35 & 0.75 & 0.75 & 0.65 & 1.10 & 1.45 \\
\hline Dy & 5.5 & 5.4 & 5.5 & 5.5 & 2.4 & 2.4 & 3.0 & 3.4 & 5.3 \\
\hline $\mathrm{Er}$ & 3.7 & 3.5 & 3.6 & 3.5 & 1.4 & 1.5 & 1.5 & 2.3 & 3.7 \\
\hline $\begin{array}{l}\mathrm{Yb} \\
\mathrm{La}\end{array}$ & 3.45 & 3.45 & 3.38 & 3.43 & 1.43 & 1.45 & 1.45 & 2.08 & 3.45 \\
\hline $\mathrm{Sc}$ & 18.5 & 18.5 & 18.0 & 18.5 & 38.0 & 38.0 & 37.0 & 45.0 & 17.0 \\
\hline V & 153 & 150 & 150 & 153 & 371 & 378 & 375 & 520 & 137 \\
\hline $\mathrm{Cr}$ & 3 & 4 & 3 & 5 & 73 & 63 & 63 & 30 & 9 \\
\hline Co & 20 & 19 & 18 & 19 & 41 & 40 & 40 & 38 & 18 \\
\hline $\mathrm{Ni}$ & 5 & 5 & 5 & 6 & 54 & 49 & 50 & 20 & 8 \\
\hline $\mathrm{Y}$ & 36 & 35 & 35 & 37 & 15 & 15 & 15 & 22 & 36 \\
\hline $\mathrm{Nb}$ & 1.45 & 1.5 & 1.3 & 1.7 & 0.6 & 0.5 & 0.5 & 0.65 & 1.5 \\
\hline
\end{tabular}


TABLE \|

(Comtinued)

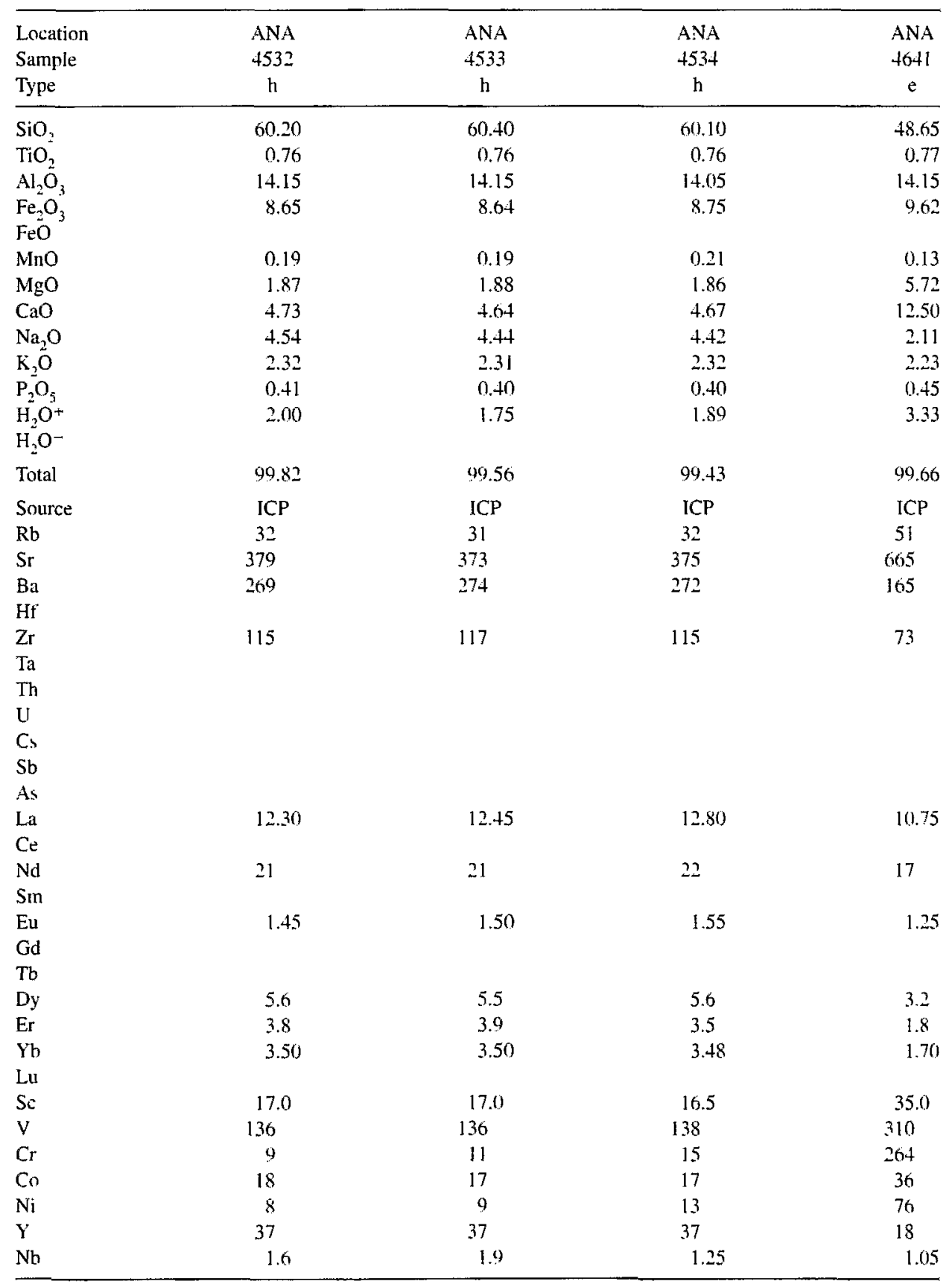


TABLE III

K/Ar Ages of Volcanic Samples ${ }^{a}$

\begin{tabular}{|c|c|c|c|c|c|}
\hline Sample & Age (Ma) & Type & Sample & Age (Ma) & Type \\
\hline \multicolumn{3}{|c|}{ Jean-Charcot Troughs } & \multicolumn{3}{|c|}{ Coriolis Troughs } \\
\hline \multicolumn{3}{|c|}{ Vanikoro area (VAN) } & \multicolumn{3}{|c|}{ Efate area (EFA) } \\
\hline $7 \mathrm{M} 2$ & $12.4 \pm 0.9$ & a & $27 \mathrm{M} 12$ & $3.5 \pm 0.3$ & d \\
\hline 3M4 & $1.1 \pm 0.2$ & f & 29M6 & $3.2 \pm 0.2$ & $e+d$ \\
\hline $5 \mathrm{M} 1$ & $2.9 \pm 0.4$ & f & 31M2 & $1.5 \pm 0.2$ & d \\
\hline 6M1 & $2.6 \pm 0.5$ & c & 31M1 & $1.4 \pm 0.2$ & d \\
\hline $5 \mathrm{M} 4$ & $3.9 \pm 0.6$ & $\mathrm{f}$ & $30 \mathrm{M} 2$ & $1.4 \pm 0.2$ & d \\
\hline 3M3 & $1.8 \pm 0.3$ & $\mathrm{f}$ & 30M1 & $1.1 \pm 0.2$ & d \\
\hline $7 \mathrm{M} 4$ & $2.3 \pm 0.2$ & $e+c$ & $27 \mathrm{M} 17$ & $3.4 \pm 0.2$ & $\mathrm{i}$ \\
\hline 3M1 & $1.8 \pm 0.1$ & $\mathrm{~g}$ & $27 \mathrm{Ml}$ & $2.2 \pm 0.1$ & $\mathbf{i}$ \\
\hline $3 \mathrm{M} 2$ & $1.5 \pm 0.4$ & $\mathrm{~g}$ & $27 \mathrm{M} 4$ & $2.4 \pm 0.1$ & $\mathbf{i}$ \\
\hline $1 \mathrm{M} 9$ & $1.5 \pm 0.1$ & $\mathrm{~g}$ & 29M3 & $3.0 \pm 0.2$ & $\mathrm{i}$ \\
\hline $1 \mathrm{M} 8$ & $1.1 \pm 0.2$ & $\mathrm{~g}$ & $28 \mathrm{M} 1$ & $2.2 \pm 0.2$ & $\mathbf{i}$ \\
\hline 1M5 & $<0.3$ & $\mathrm{~g}$ & $26 \mathrm{M} 6$ & $0.4 \pm 0.05$ & $\mathrm{~h}$ \\
\hline $1 \mathrm{M} 3$ & $1.1 \pm 0.2$ & $\mathrm{~g}$ & $26 \mathrm{M} 7$ & $0.5 \pm 0.1$ & h \\
\hline 3152 & $<0.3$ & $\mathrm{~g}$ & \multicolumn{3}{|c|}{ Erromango area (ERR) } \\
\hline \multicolumn{3}{|c|}{ Tikopia area (TIK) } & $25 \mathrm{M} 2$ & $4.1 \pm 0.3$ & $\mathrm{c}$ \\
\hline $3981 \mathrm{x}$ & $3.7 \pm 0.2$ & $\mathrm{e}$ & $25 \mathrm{M} 4$ & $4.0 \pm 0.6$ & c \\
\hline $415 \mathrm{X}$ & $<0.3$ & $\mathrm{~g}$ & $24 \mathrm{M} 6$ & $3.6 \pm 0.2$ & b \\
\hline \multicolumn{3}{|c|}{ Vot Tande area (VOT) } & $24 \mathrm{M} 4$ & $4.1 \pm 0.2$ & d \\
\hline $11 \mathrm{MI}$ & $4.9 \pm 0.2$ & $\mathrm{e}+\mathrm{c}$ & $24 \mathrm{M} 3$ & $2.7 \pm 0.1$ & $\mathrm{~h}$ \\
\hline $10 \mathrm{M} 1$ & $2.8 \pm 0.1$ & $c$ & \multicolumn{3}{|c|}{ Futuna area (FUT) } \\
\hline 10M2 & $2.7 \pm 0.1$ & c & 19M1 & $2.6 \pm 0.2$ & $c+d$ \\
\hline $12 \mathrm{M} 1$ & $2.8 \pm 0.1$ & $d$ & $21 \mathrm{M} 7$ & $6.5 \pm 0.5$ & $\mathrm{~d}$ \\
\hline 11M2 & $4.8 \pm 0.2$ & $e+c$ & $21 \mathrm{M} 1$ & $6.1 \pm 0.3$ & $e+d$ \\
\hline \multirow{2}{*}{\multicolumn{3}{|c|}{ Hazel Holme area (HAZ) }} & $16 \mathrm{M} 1$ & $5.2 \pm 0.3$ & $\mathrm{e}$ \\
\hline & & & $17 \mathrm{M} 3$ & $6.1 \pm 0.3$ & $\mathrm{e}$ \\
\hline $14 \mathrm{M} 2$ & $5.2 \pm 0.8$ & $\mathbf{a}$ & $20 \mathrm{M} 6$ & $0.7 \pm 0.2$ & $\mathrm{c}$ \\
\hline 14M1 & $5.5 \pm 0.4$ & $\mathbf{a}$ & 20M1 & $0.7 \pm 0.3$ & $\mathrm{c}$ \\
\hline 15M6 & $4.1 \pm 0.2$ & b & & & \\
\hline $15 \mathrm{M} 12$ & $3.5 \pm 0.3$ & $\mathrm{i}$ & & & \\
\hline
\end{tabular}

aSee Monjaret (1989) and Monjaret et al. (1991) for analytical procedure.

Footnote to Table II.

aPetrological types a to i correspond to mid-ocean ridge basalts (MORB) (a), IAT (island-arc tholeiites) (b, c, d), calc-alkaline basalts and andesites (CAB) (e), backarc basin basalts (BABB) (f), high-Na/low-K dacites (g), high-K dacites (h), and hyper-K dacites (i), respectively (see text for discussion).

Analytical methods: $\mathrm{AA}=$ atomic absorption (J. Cotten, $\mathrm{UBO}$ ). $\mathrm{XRF}=\mathrm{X}$-ray fluorescence (R. C. Price, La Trobe University; S. Nakada, Kyushu University). INA = instrumental neutron activation (J. L. Joron, Pierre-Süe; A. Fujinawa, Ibaraki University, for 3321, 3152, 4152, 415X, 3981X, 3982, 3983, 4294, 4295, CY11, CY31, CY34, CY36; see Nakada et al., 1994). ICP = inductively coupled plasma emission spectrometry (ICP-ES, J. Cotten, UBO). Note: For 3151, 3154, 3981, 4150, 4151, 4153, and 4155, Nb and REE by ICP (J. Cotten, UBO); for 3M1, 10MI, 10M2, 27M1, and 24M3, Cr by AA (J. Cotten, UBO); for all analyses, V by AA (J. Cotten, UBO) or XRF (S. Nakada, Kyushu University, for the 13 analyses listed in INA).

Analytical procedure for inductively coupled plasma emission spectrometry (ICP-ES) and atomic absorption spectrometry (AA) analyses (J. Cotten, UBO): Rock powders were digested in closed vessels with $4 \mathrm{ml}$ of a concentrated hydrofluoric/nitric acid mixture. $\mathrm{H}_{3} \mathrm{BO}_{3}$ was then added to dissolve the precipitated fluorides and to neutralize the excess HF. International standards (JB1, JB2, BEN, Mica-Fe, GSN, ACE) were used for calibration.

Major elements except $\mathrm{P}_{2} \mathrm{O}_{5}$ : AA analyses with a relative standard deviation (RSD) close to $2 \% . \mathrm{P}_{2} \mathrm{O}_{5}$ : colorimetry with a standard deviation of $0.05 \%$.

Trace elements: Rb, Sr (AA), limit of detection (LOD): 1 ppm, RSD: 5\%; Ba, V (AA), LOD: 25 ppm; RSD: 10\%; Cr, Co, Ni (AA): LOD: 2 ppm; RSD: 5\%; Ce, Nd, Zr (ICP-ES), LOD: 2 ppm; RSD: 5\%; Nb, La, Er (ICP-ES), LOD: 1 ppm; RSD: 5\%; Sc, Y, Dy (ICP-ES), LOD: 0.5 ppm, RSD: 5\%; Eu, Yb (ICP-ES), LOD: 0.2 ppm; RSD: 5\%. 


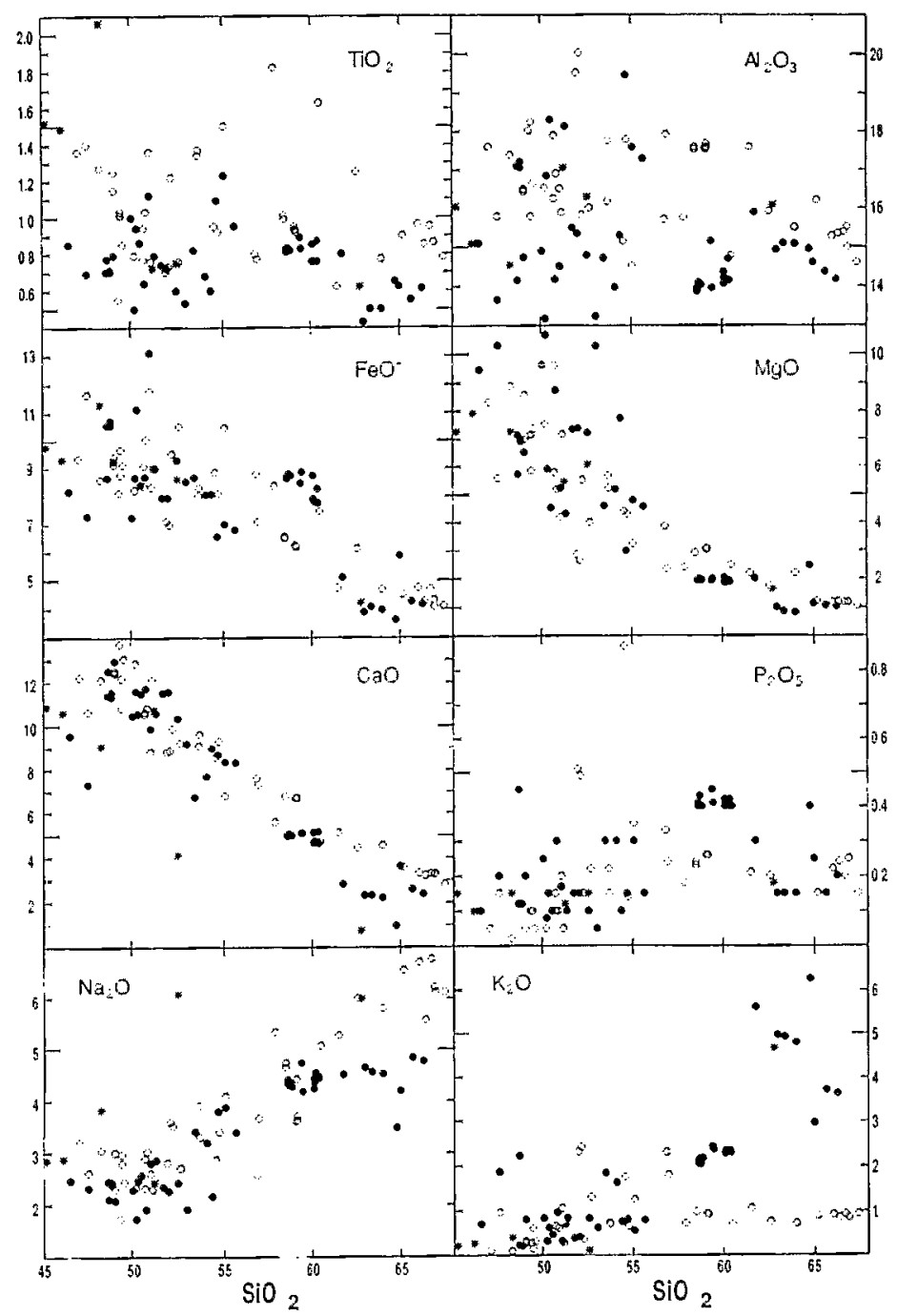

FIGURE 5.16. Major elements 1 fri versus $\mathrm{SiO}_{2}$ ( $\%$ ) diagrams for volcanic samples from the NHBAT. Open circles: northern Jean-Charcot troughs (JCT); filled circles: southern Coriohs troughs (CT): asterisks: western termination of the Hazel Holme Ridge. Data from Table II.

with an average of $74 \mathrm{~mW} / \mathrm{m}^{2}$, indicating a rather low heat flow. The highest value $(161$ $\mathrm{mW} / \mathrm{m}^{2}$ ) was recorded at station 40 in the Tikopia area $12^{\circ} 46.033^{\prime} \mathrm{S}-167^{\circ} 49.504^{\prime} \mathrm{E}$ : water depth: $3027 \mathrm{~m}$ : Fig. 5.5). This is comparable to the mean of heat flow values on the North Fiji Basin seafloor (150-250 mW/m²) (KAIYO 89 Cruise Report. 1990).

One of the aims of the SAVANES cruise (1991) was to conduct dives with the Cyant submersible on possible active hydrothermal sites in the JCT. previously surveyed during the KAIYO 89 cruise. Diplomatic restrictions imposed by Solomon Islands authorities, relating to their 200 nautical mile boundary, prevented dives at station 31, and consequently the KAIYO 89 observation could not be confirmed. However, a living biological community was discovered southward, at station 41 in the Tikopia area. near sampling cite 

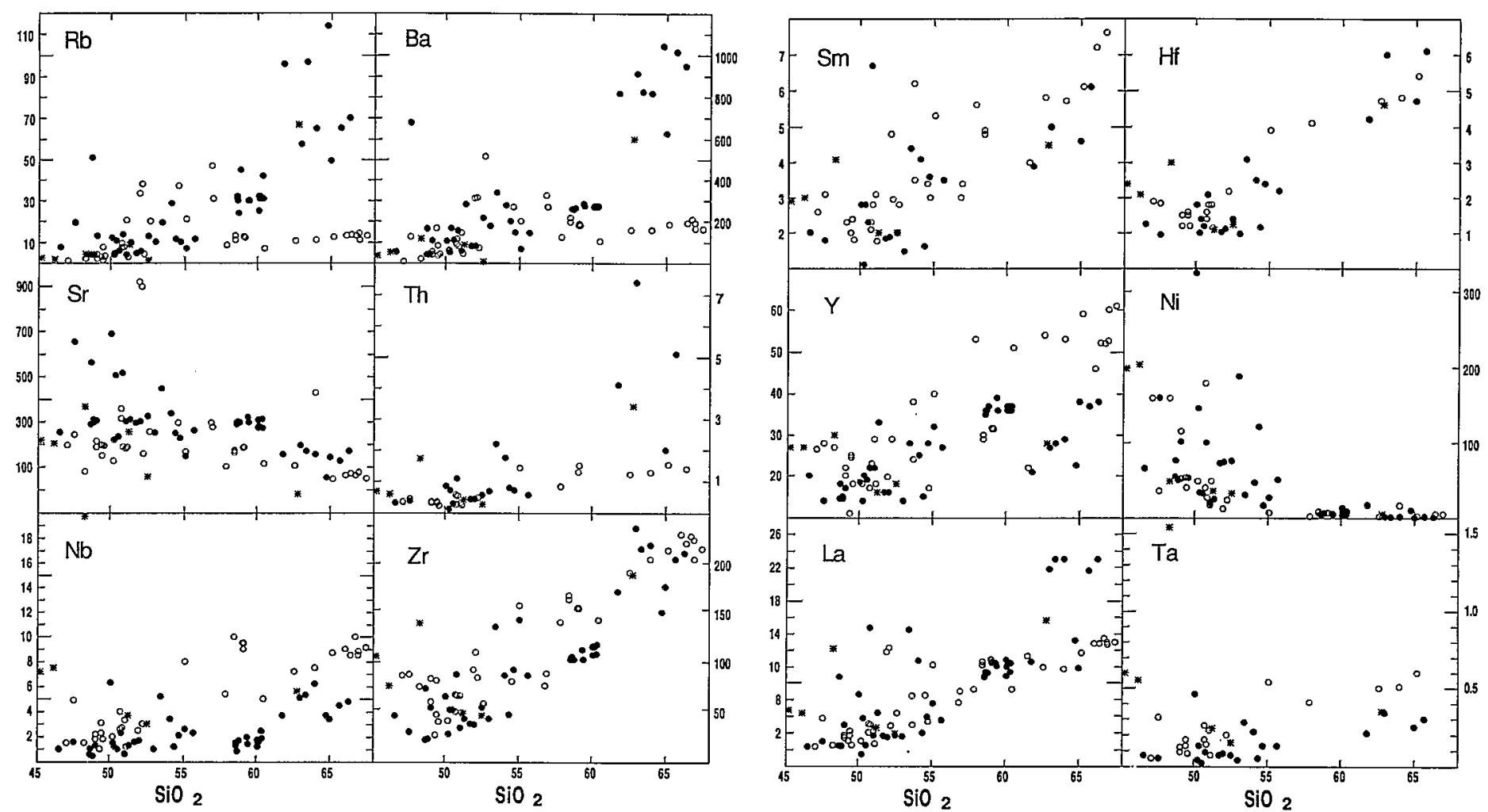

FIGURE 5.17. Trace elements (ppm) versus $\mathrm{SiO}_{2}(\%)$ diagrams for volcanic samples from the NHBAT. Same symbols as in Fig. 5.16. Data from Table II. 


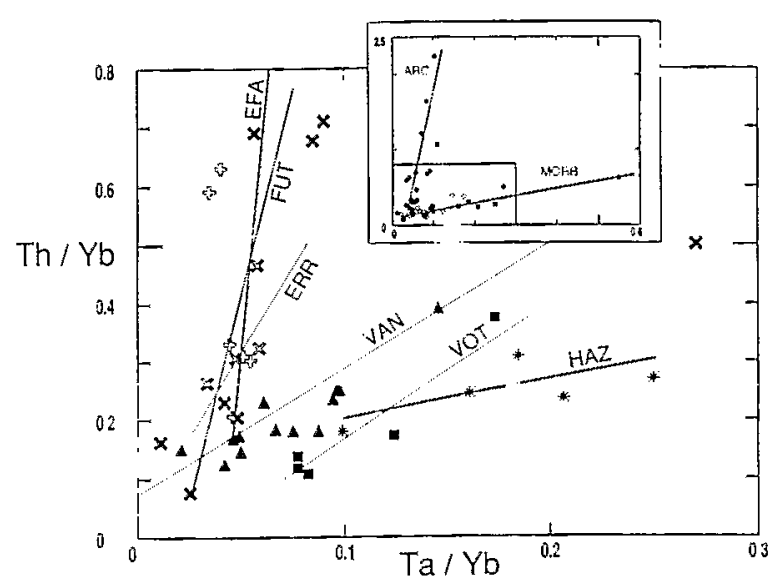

FIGURE 5.18. Th/Yb versus $\mathrm{Ta} / \mathrm{Yb}$ diagram for volcanic samples from the NHBAT. Data from Table II. JCT samples: filled triangles (Vanikoro area, VAN) and filled squares (Vot Tande area. VOT). Hazel Holme samples: asterisks. CT samples: open crosses (Efate area. EFA), oblique open crosses (Erromango area. ERR) ant oblique filled crosses (Futuna area, FUTı. An arbitrary correlation line for each area is indicated. The extended diagram is shown in inset. JCT samples: filled circles; Hazel Holme samples: asterisks: CT samples: open circles. ARC and MORB fields are indicated as arbitrary lines.

CY36 (Table I: Fig. 5.5). On the summit of the eastern seamount of station 41 $\left(12^{\circ} 32.6^{\prime} \mathrm{S}-167^{\circ} 47.3^{\prime} \mathrm{E}\right)$, at a depth of $1425 \mathrm{~m}$, the Cyana submersible team discovered and videotaped a flourishing colony of algae, sponges, corals, galatheas. and shrimp resting on a $50 \times 50 \mathrm{~m}$ peak of massive to blocky lava. Shimmering water was not observed on the spot during the dive nor on the video records, but a local increase in seawater temperature $\left(3.27^{\circ} \mathrm{C}\right.$ instead of $2.52^{\circ} \mathrm{C}$ in the surroundings) might suggest a hydrothermal environment (SAVANES 91-92 Cruise Report, 1992). However, chemical analyses of seawater sampled on this site did not confirm this hypothesis (D. Grimaud, personal communication).

\subsubsection{Ferromanganese Crusts}

The study of ferromanganese crusts in island arcs gives good environmental criteria to distinguish hydrothermal impact from sedimentary processes.

During the R/V Jean Charcot SEAPSO 2 cruise. 18 sites bearing ferromanganese crusts were dredged in the NHBAT, in water depths ranging from 500 to $3000 \mathrm{~m}$. along fault scarps or volcanic cones (Fig. 5.20: Gérard et al., 1987: Gérard, 1993). The crusts were dredged in five Sea Beam-surveyed areas, two in the northern JCT. Vanikoro (VAN) and Vot Tande (VOT), and three in the southern CT. Efate (EFA), Erromango (ERR), and Futuna (FUT). The more complex ferromanganese crusts are essentially located on volcanic cones in the Vanikoro area and along the eastern faulted border of the Futuna Trough. Most of the crusts show coatings 0.1 to $1 \mathrm{~cm}$ thick on volcaniclastic rocks. However, the complex crusts from dredges SPS2D4. SPS2D5 (Vanikoro area) and SPS2D19 (Futuna area) cover and impregnate the volcano-sedimentary deposits up to $10 \mathrm{~cm}$ thick or show massive figures.

The main oxyhydroxide manganiferous phases present in these crusts are vernadite (a low-crystalline manganese oxide mineral), todorokite, and buserite. Birnessite is less common. The mineralogical structure of todorokite. buserite, and birnessite refers to the 
evolution of 10- $\AA$ and 7- $\AA$ manganates (Person, 1980; Usui et al., 1989). Buserite is an instable 10- $\AA$ manganate which transforms to a 7- $\AA$ manganate upon dehydration; todorokite is a stable $10-\AA$ manganate, and birnessite is a stable $7-\AA$ manganate. These minerals are good criteria to distinguish hydrothermal and hydrogenous processes. Based on microstructural and mineralogical data, two major genetical types of ferromanganese encrustations are found in the NHBAT, a thalassic type and a hydrothermal type (Gérard, 1993).

In the thalassic type, the common crusts consist of $\mathrm{dMnO}_{2}$ (vernadite) and amorphous $\mathrm{FeOOH}, \mathrm{xH}_{2} \mathrm{O}$. Samples from SPS2D4 and SPS2D5 dredges (Vanikoro area; Fig. 5.20) show such coatings on volcaniclastic rocks which are interpenetrated by buserite with dendritic structures (Fig. 5.21). These crusts of hydrogenous precipitations display botryoidal microstructures associated with bacteriomorph occurrences (Fig 5.21), and are characterized by simultaneous precipitation of $\mathrm{Fe}$ and $\mathrm{Mn}$ (Table IV).

The hydrothermal type is characterized by stable todorokite (which resists transformation upon dehydration), celadonite (Fe-phyllosilicate), amorphous Fe hydroxide (goethite), or birnessite. Paleohydrothermalism is characterized by a Fe-Mn segregation on a macroscale, with patches of todorokite and celadonite, and amorphous Fe-phase. This todorokite displays a well-crystallized microstructure, namely spheres of todorokite with lamellar shape (Fig. 5.22). Celadonite may be the result of the evolution of hydrothermal, "metastable" nontronite (Alt, 1988; Weaver, 1989); it also may result from the slow evolution of biogenic silica and hydrothermal iron or from direct precipitation associated with low hydrothermal activity (Odin and Desprairies, 1988). Birnessite crusts similar to those of the vents of Teahitia submarine volcano in the central Pacific (Hoffert et al., 1987) are rarer. They are attributed to a more recent hydrothermal phase. A latter stage of hydrothermal activity is also noticeable. Thin cracks of micritic calcite and phillipsite cut the Mn deposits in some todorokite crusts. They do not contain any biogenic fraction, in contrast to the major and older cracks. These crystallizations in the thin cracks are attributed to a last phase of hydrothermal activity.

Chemically, these two types of ferromanganese encrustations can also be distinguished (Table IV): high $\mathrm{Mn} / \mathrm{Fe}$ ratios and low $\mathrm{Co}+\mathrm{Ni}+\mathrm{Cu}$ contents characterize the hydrothermal encrustations, whereas low $\mathrm{Mn} / \mathrm{Fe}$ ratios and "higher" $\mathrm{Co}+\mathrm{Ni}+\mathrm{Cu}$ contents characterize the thalassic (hydrogenous) coatings and impregnations. Based on correlation values between major, trace, and rare-earth elements (REE) within the two types of crusts (Gérard, 1993), the principal differentiations are as follows:

1. Si or Fe and REE are positively correlated in the hydrothermal (todorokite) crusts, which is attributed to the adsorption of REE on clays (celadonite), and negatively correlated in the thalassic crusts.

2. $P$ and REE are positively correlated in the thalassic (hydrogenous) group; no significative correlation appears for $\mathrm{P}$ in the hydrothermal (todorokite) group. The behavior of REE is mostly attributed to oxidation processes, the todorokite phase being a relatively oxidant phase. The two types of crusts (thalassic and hydrothermal) are therefore essentially controlled by redox conditions. Other determining factors are the low mobility of $\mathrm{Al}$ and $\mathrm{Ti}$ during the thalassic alteration phase. The high $\mathrm{Si} / \mathrm{Ti}$ ratio characterizes the hydrothermal influence.

In summary, the ferromanganese crusts dredged along the NHBAT can be classified into two types: thalassic and hydrothermal. The common Fe-Mn crust is a vernadite coating. The more complex crusts are made up of todorokite, buserite, and birnessite, associated with a goethite-celadonite facies. 


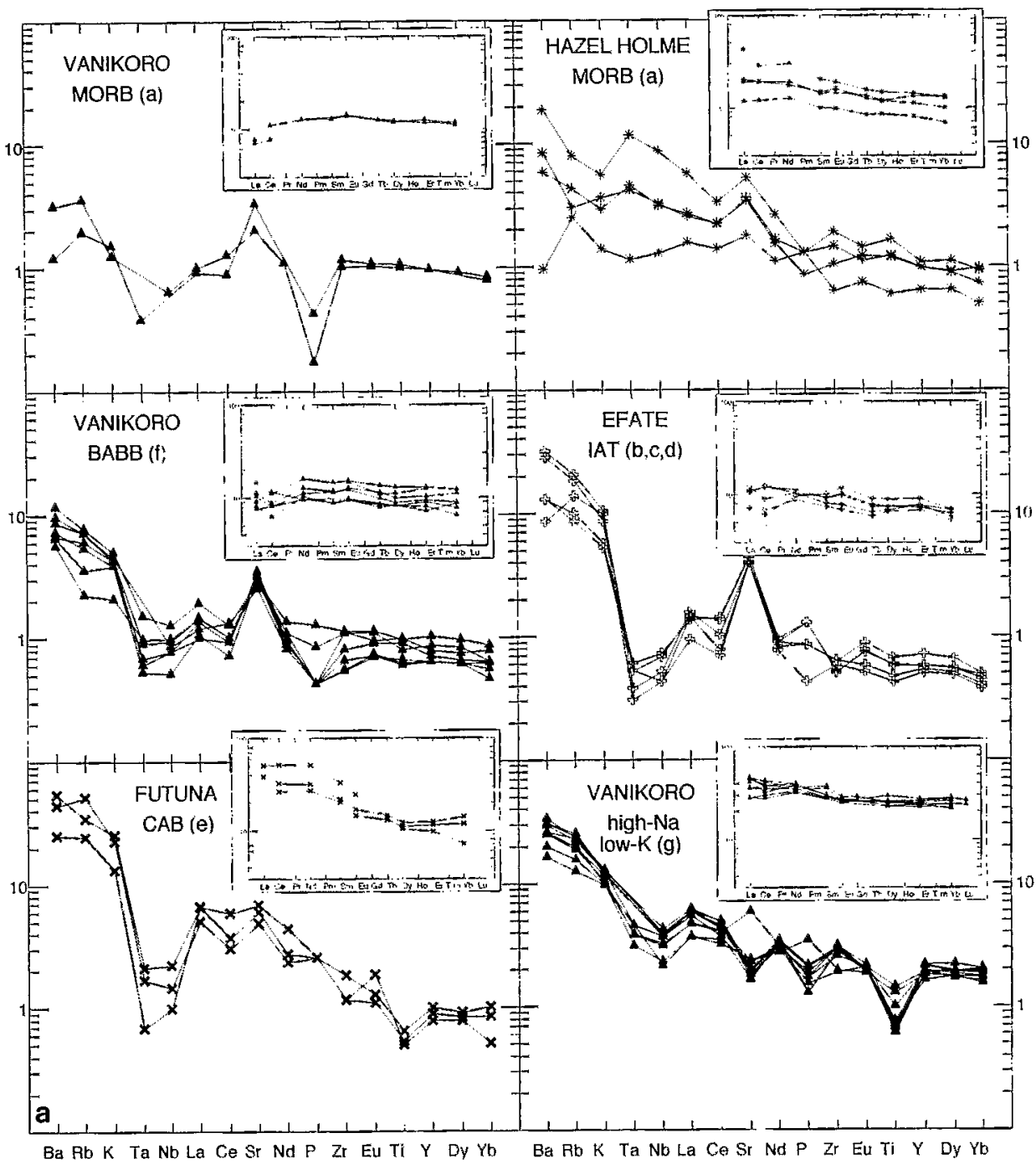

FIGURE 5.19. (a,b). N-MORB normalized "spiderdiagrams" and chondrite-normalized REE patterns (insets) for volcanic samples from the NHBAT. Data from Table II. Normalizing values: Sun and McDonough (1989) for "spiderdiagrams," Nakamura (1974) for REE. Letters in parentheses ia to i) refer to the different petrological types of Table II. Note on Fig. $5.19 \mathrm{~b}$ the chatge of vertical scale for the two bottom "spiderdiagrams" ihigh-K and hyper-K dacites). See text for discussion.

The most evolved thalassic crusts (vernadite and buserite) were dredged in the Vanikoro area (northern Jean-Charcot troughs) on a lateral cone of the $12^{\circ} 10^{\prime} \mathrm{S}$ central volcanic complex (D5: Fig. 5.20; Table IV).

The hydrothermal crusts were dredged in the Jean-Charcot troughs on a volcanic cone located at the eastern border of the same area (D4; Fig. 5.20; Table IV) and in the southern Coriolis troughs on the eastern faulted border of the Futuna Trough (D19; Fig. 5.20; Table IV). Three successive stages of hydrothermal activity have been identified. each with 


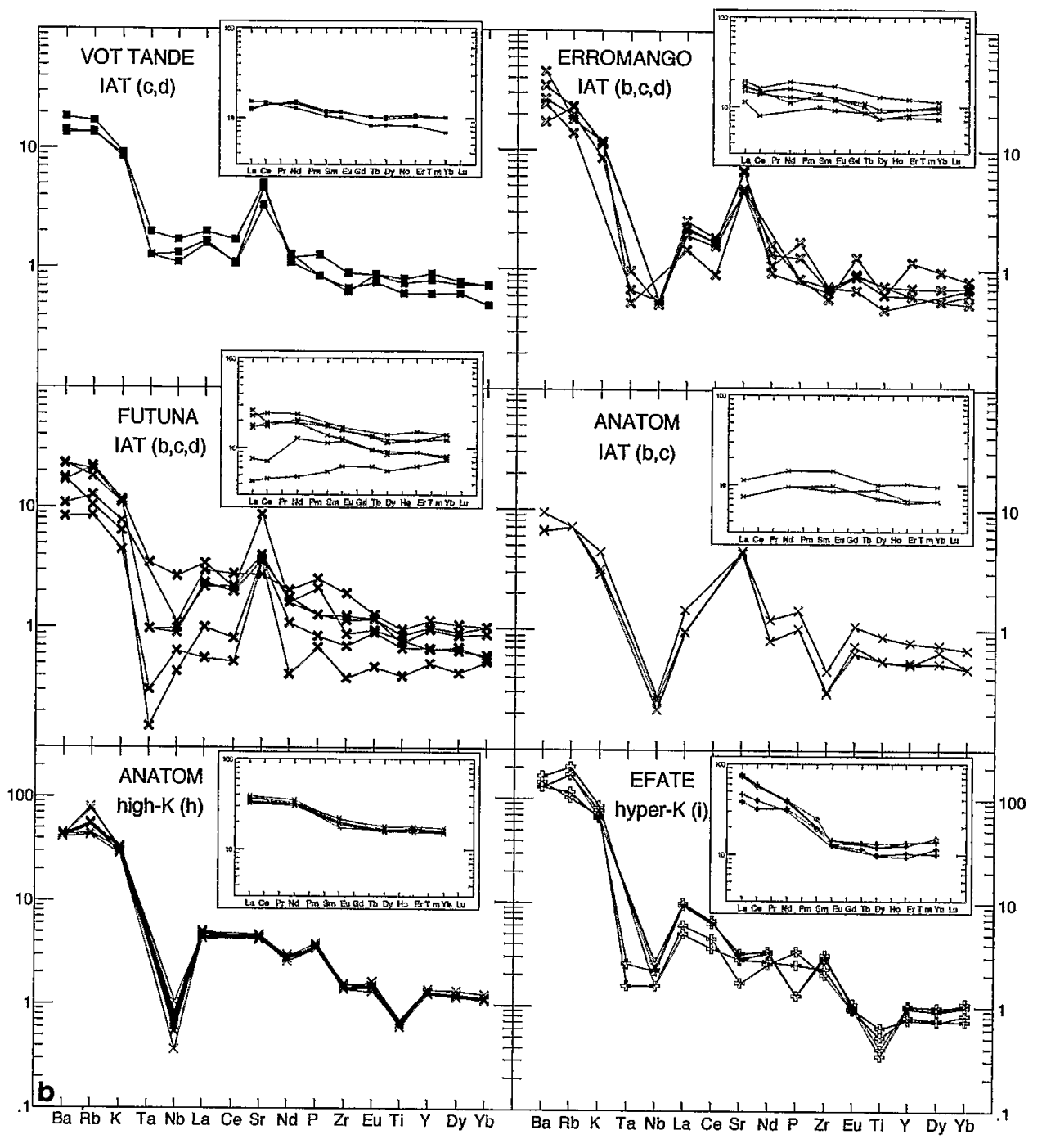

FIGURE 5.19. (Continued)

specific mineralizations. An ancient stage is characterized by todorokite and celadonite; a more recent stage is characterized by birnessite; a late hydrothermal stage, marked by micritic calcite and phillipsite in todorokite crusts, is thought to be relatively recent. This low hydrothermal activity seems essentially limited to the eastern border of the New Hebrides backarc troughs.

\section{DISCUSSION AND CONCLUSIONS}

This review of the NHBAT emphasizes a few regional and thematic points, which are summarized as follows. 


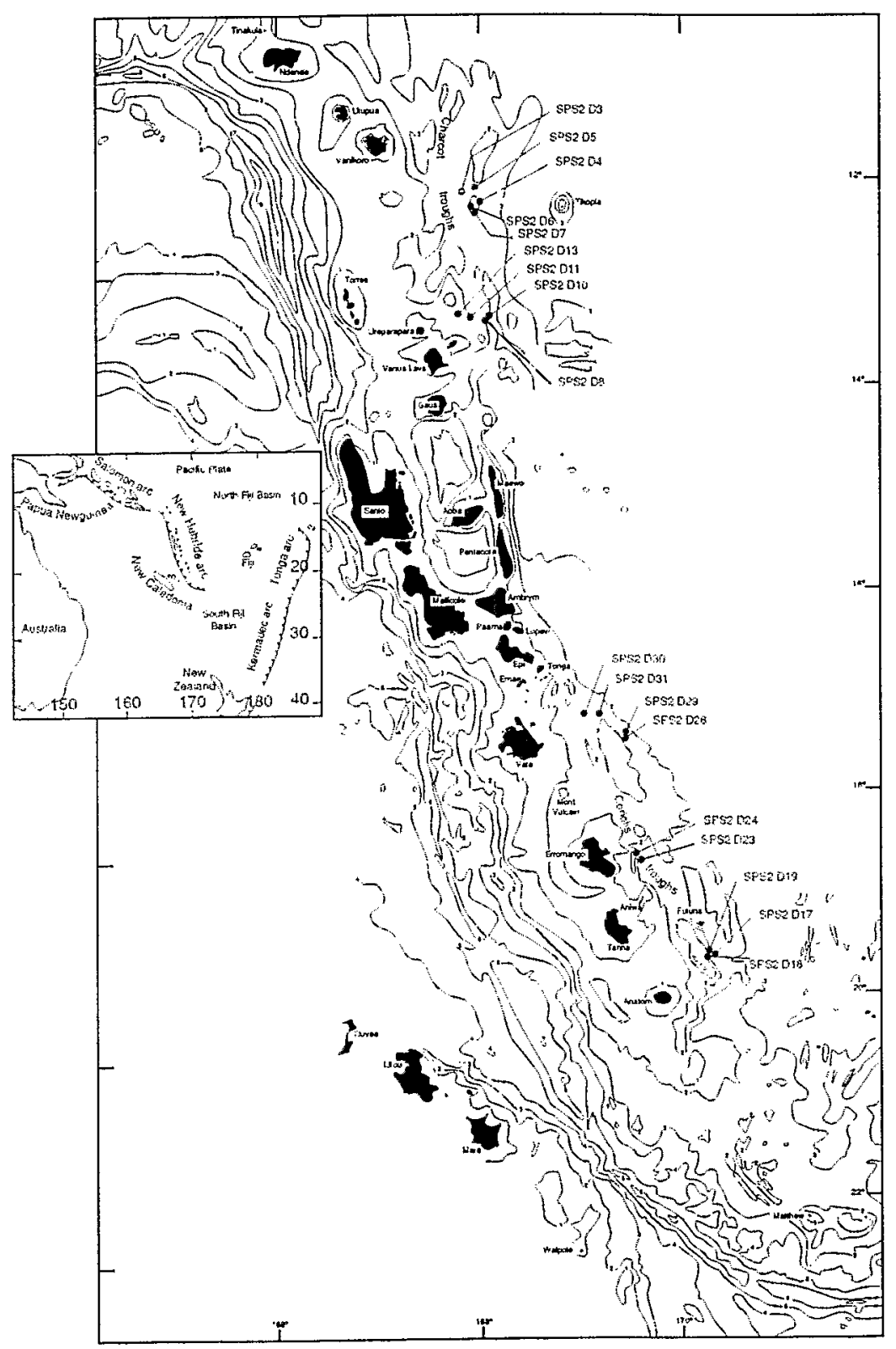

FIGURE 5.20. Location of ferromanganese crusts dredged in the Jeant-Charcot and Coriolis trulghs 1Gerard. 1993). Acronym SPS2 atands tor SEAPSO 2 cruise. See also Fig. 5.14 for comparison. 

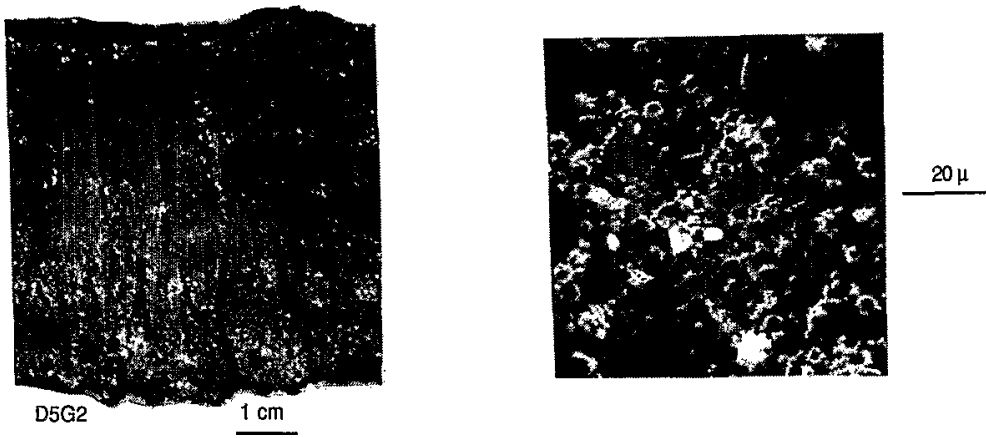

FIGURE 5.21. (Left): Macroscopic view of vernadite crusts with diagenetic buserite dendrites on volcanic sandstone. (Right): SEM view of bacteriomorphs in the vernadite crust.

1. The NHBAT correspond to a discontinuous alignment of tensional structures, bordering the eastern flank of the New Hebrides island arc. A diffuse horst-and-graben morphology, partly obscured in some places by recent volcanic complexes, characterizes the northern JCT. The general orientation of these northern troughs is slightly oblique to the arc central chain. In contrast, the southern CT show a more mature morphology (i.e., welldeveloped and clearly delineated flat-bottomed grabens), which strictly parallel the arc.

2. Several characteristics of these troughs are paradoxical.

(a) Seismic refraction and gravimetry studies (Collot and Malahoff, 1982; Pontoise et al., 1982; Sage and Charvis, 1991) indicate that the NHBAT partly developed on an ancient oceanic crust similar to that of the NFB. $\mathrm{N} 130^{\circ} \mathrm{E}$ magnetic lineations recognized in the NHBAT (JCT and CT) are typical of the magnetic pattern of the oldest part of the NFB and corroborate this point (Charvis and Pelletier, 1989; Sage and Charvis, 1991).

(b) The respective positions of the northern and southern troughs in the regional tectonic environment are different (Charvis and Pelletier, 1989). The northern Jean-Charcot troughs abut the western termination of the extensional Hazel Holme Ridge, from where they diffusely extend and widen northward. No subaerial volcanic edifice exists on the arc central chain between Vot Tande and Vanikoro Islands (i.e., opposite the troughs area). On the other hand, the southern Coriolis troughs strictly lie opposite Efate, Erromango, Tanna, and Anatom Islands. They terminate south of the latter island, where they merge into the island arc substratum. Furthermore, they are located well away from the N-S axis of the North Fiji Basin active spreading ridge (Monzier et al., 1984b; Maillet et al., 1989), and, consequently, any direct influence of this expanding ridge on the petrological evolution of these troughs can be excluded.

(c) As noted, two ridges of regional scale frame the backarc area; the d'Entrecasteaux zone on the subducting plate, and the Hazel Holme Ridge on the North Fiji Basin. Their tectonomagmatic influences on the formation of the NHBAT still remain to be deciphered. Two remarks can be made. First, the collision of the d'Entrecasteaux zone with the New Hebrides arc started around 4-3 Ma (Macfarlane et al., 1988); second, the Hazel Holme Ridge acts as an extensional structure in its westernmost termination (Pelletier et al., 1993a), namely, at the southern tip of the Jean-Charcot troughs. It is then possible that the structural and petrological differences observed between the northern and southern troughs may be due, at least in part, to the influences of these two ridges. 
TABLE N

Major Element Contents (wt $\%$ ). Minor and Rare Earth

Element (REE) Contents (ppm) of Some Typical

Hydrothermal and Thalassic Ferromanganese Crusts

\begin{tabular}{|c|c|c|c|c|c|}
\hline \multicolumn{3}{|c|}{ Hydrothermal crusts } & \multicolumn{3}{|c|}{ Thalassic crusts } \\
\hline Samples & $\mathrm{D} 4 \mathrm{G} 9$ & D19G3 & D5G2X & D5G2Y & D112G6 \\
\hline $\mathrm{Fe}(w \mathrm{t} / \mathrm{c})$ & 0.27 & 2.36 & 19.17 & 9.89 & 18.93 \\
\hline $\mathrm{Mn}$ & 38.03 & 38.57 & 11.33 & 14.71 & 10.16 \\
\hline $\mathrm{Si}$ & $i .31$ & 4.69 & 6.8 & 7.8 & 4.16 \\
\hline $\mathrm{Al}$ & 0.36 & 1.7 & 2.58 & 3.45 & 2.75 \\
\hline $\mathrm{Mg}$ & 3.02 & 2.27 & 1.36 & 1.73 & 1.08 \\
\hline $\mathrm{Ca}$ & 5.49 & 1.89 & 2.41 & 4.8 & 2.87 \\
\hline $\mathrm{Na}$ & 1.37 & 2.16 & 1.73 & 1.7 & 1.79 \\
\hline $\mathrm{K}$ & 0.32 & 0.68 & 0.56 & 0.51 & 0.5 \\
\hline $\mathrm{Ti}$ & tr & 0.1 & 0.89 & 0.58 & 1.03 \\
\hline$P$ & 0.03 & 0.04 & 0.15 & 0.08 & 0.10 \\
\hline Co (pprn) & 29 & 51 & 1238 & 499 & 1433 \\
\hline $\mathrm{Cr}$ & 1294 & 1227 & 231 & 428 & 160 \\
\hline $\mathrm{Cu}$ & 22 & 45 & $46 ?$ & 199 & 563 \\
\hline $\mathrm{Nb}$ & 24 & 14 & 44 & 31 & 46 \\
\hline $\mathrm{Ni}$ & 227 & 157 & 1829 & 731 & 1352 \\
\hline $\mathrm{Zn}$ & 44 & 40 & 695 & 563 & 555 \\
\hline $\mathrm{Mn} / \mathrm{Fe}$ & 140.85 & 16.34 & 0.59 & 1.49 & 0.54 \\
\hline $\mathrm{Mn} / \mathrm{Ti}$ & 3803 & 385.7 & 12.73 & 25.36 & 9.86 \\
\hline $\mathrm{Fe} / \mathrm{Ti}$ & 27 & 23.6 & 21.54 & 17.015 & 18.38 \\
\hline $\mathrm{Co} / \mathrm{Zn}$ & 0.66 & 1.28 & 1.78 & 0.89 & 2.58 \\
\hline $\mathrm{Cu}+\mathrm{Ni}+\mathrm{Cu}$ & 278 & 253 & 3529 & 1429 & 3348 \\
\hline Y (ppin) & 16.5 & 7.7 & 162.1 & 82.4 & 185.7 \\
\hline $\mathrm{La}$ & 2.5 & 4.1 & 140.5 & 64 & 171.2 \\
\hline $\mathrm{Cl}^{2}$ & 7.1 & 11.8 & 214.1 & 107.3 & 286 \\
\hline $\mathrm{Nd}$ & 2 & 4.5 & 106.8 & 51 & 132.5 \\
\hline $\operatorname{Sin}$ & 0.8 & 1.7 & 24.6 & 11.9 & 31.3 \\
\hline $\mathrm{Eu}$ & 0.2 & 0.3 & 6.4 & 3.1 & 7.8 \\
\hline Gd & 0.9 & 1 & 27.9 & 1.3 .5 & 33.9 \\
\hline Dy & 5.8 & 9.3 & 28.5 & 15.7 & 35.1 \\
\hline Er & 1.1 & 0.9 & 16 & 8.1 & 19.1 \\
\hline $\mathrm{Yb}$ & 0.8 & 0.7 & 15.7 & 7.9 & 18.9 \\
\hline $\mathrm{Lu}$ & 0.4 & 0.4 & 2.2 & 1.2 & 2.8 \\
\hline SUM REE & 21.48 & 34.76 & 582.70 & 283.7 & 738.48 \\
\hline $\mathrm{La} / \mathrm{Yb}$ & 3.2 & 5.9 & 9 & 8.1 & 9.1 \\
\hline $\mathrm{Ce} / \mathrm{La}$ & 2.9 & 2.9 & 1.5 & 1.7 & 1.7 \\
\hline $\mathrm{La} / \mathrm{Sm}$ & 3.15 & 2.46 & 5.72 & 5.37 & 5.47 \\
\hline
\end{tabular}

(d) Using seismological arguments, Charvis and Pelletier (1989) proposed to link the formation of the NHBAT to a general NE-SW extensional stress regime affecting the whole western part of the North Fiji Basin as well as its borders (i.e., the Hazel Holme Ridge and the northern and southern NHBAT). This interpretation is contrary to the view of Collot et al. (1985), who argued that the aftereffects of the collision-subduction of the d'Entrecasteaux zone is the main factor responsible for the formation of the NHBAT. Thus, there is 


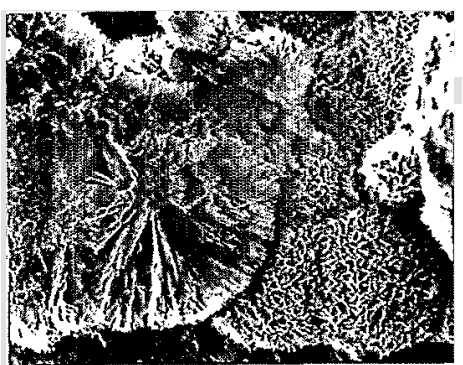

$20 \mu$

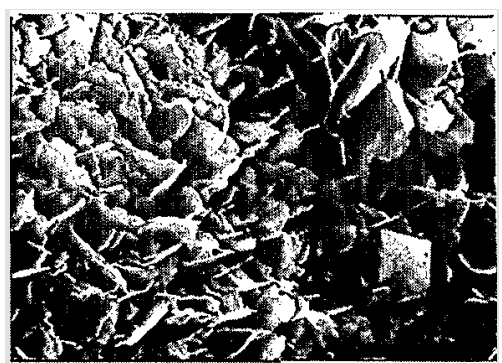

$5 \mu$

FIGURE 5.22. Todorokite facies. SEM views.

still debate concerning the respective influence of compressional and tensional stresses on the formation of the NHBAT.

3. Petrologically, no pronounced difference exists between the recent volcanic products of the New Hebrides central chain and the volcanics which crop out on the floor or on the faulted edges of the NHBAT. A ubiquitous orogenic, arc-related geochemistry prevails within the whole backarc area. Yet in the very northern part of the northern Jean-Charcot troughs, the presence of some BABB indicates an aborted tendency toward oceanic spreading, effective between 3.9 and $1.1 \mathrm{Ma}$. These unusual volcanics seem to be spatially restricted to a central volcanic complex in the northern Vanikoro area, where they neighbor coeval low-K, high-Na dacites (Nakada et al., 1994). Manned-submersible surveys, water chemistry analyses, and heat flow measurements do not indicate any widespread modern hydrothermal activity. Yet some ferromanganese crusts coating volcanic and volcanosedimentary formations result from a recent low hydrothermal activity, which is mainly limited to the eastern faulted border of the NHBAT.

4. The date of initiation of the formation of the NHBAT still remains imprecise, in spite of reliable K/Ar ages (Table III; Monjaret et al., 1991) and micropaleontological determinations (Gérard, 1993). There is a consensus that the age and nature of the volcanic and volcano-sedimentary formations sampled in the troughs or on their flanks are linked to the historical evolution of the New Hebrides central chain. However, Monjaret et al. (1991) argued that the formation of the NHBAT progressed from south to north, through successive volcano-tectonic phases. The Coriolis troughs developed first (the Futuna Trough around 6.5-6.1 Ma; the Erromango Trough around 4.1 Ma; the Efate Trough around 3.5 Ma) with the formation of the Jean-Charcot troughs (Vot Tande area, 2.7 Ma; Vanikoro area, $2.3 \mathrm{Ma}$ ) being more recent. Collision of the d'Entrecasteaux zone with the arc commenced around 4-3 Ma. This last tectonic phase affected the entire backarc region. In contrast, Récy et al. (1990) observed that arc tholeiitic eruptions on the eastern scarps of the NHBAT mostly ceased between 2.8 and $2.3 \mathrm{Ma}$. Accordingly, they argued that only one major tectonic phase was responsible for the formation of the NHBAT, between those two dates.

5. The NHBAT can be compared with the series of backarc structures and marginal basins from the western Pacific. If these are collectively considered to represent various stages of an evolving process leading to oceanic spreading through crustal extension and rifting, the NHBAT stand at the very least evolved point; that is, they are essentially 
characterized by crustal extension. Rifting without spreading occurs in the Okinawa Trough (Sibuet et al., 1987; Chapter 9 this volume) and in the Bonin Trough (Sumisu and Torishima rifts) (Leg 126 Scientific Drilling Party, 1989; Leg 126 Shipboard Scientific Party, 1989; Taylor et al.. 1990. 1991, 1992; Taylor, 1992). Oceanic spreading occurs in the Lau Basin (Hawkins and Melchior, 1985; Hawkins et al., 1990; Chapter 3 this volume: Leg 135 Scientific Party. 1992) and the North Fiji Basin (Auzende et al. 1990; Chapter 4 this volume).

In the NHBAT, arc lavas overwhelmingly predominate on BABB, as they do in the Okinawa Trough (Ishizuka et al. 1990). In contrast. rifting in the Bonin Trough is accompanied by a more pronounced BABB signature (Ikeda and Yuasa. 1989: Fryer et al. 1990: Hochstaedter et al., 1990a.b; Tatsumi et al., 1992; Taylor, 1992). Predominating BABB and MORB petrology is found in the Lau and North Fiji basins, where arc influences tend to diminish (Frenzel et al., 1990; Price et al.. 1990; von Stackelberg and von Rad. 1990: Johnson and Sinton, 1990: Eissen et al., 1991: 1994; Sigurdsson et al. 1993).

In conclusion. the volcanic-tectonic evolution of the New Hebrides backarc troughs results primarily from the concomitant effects of nearby subduction (along the New Hebrides subduction zone) and spreading (in the central North Fiji Basin), and secondarily from the aftereffects of collision (between the d'Entrecasteaux zone and the New Hebrides island arc). The long and complex history of the New Hebrides island arc, the maturity of the North Fiji Basin and its nonrigid plate behavior (Jarvis et al.. 1993) are thought to account for the progressive formation of such extensional structures.

\section{Acknowledgments}

Thanks are due to captains and crews of research ships and to chief scientists and scientific parties of numerous cruises. who helped, all together, collect data used in this chapter. Thanks also to Jean-Philippe Eissen (ORSTOM Brest), whose competence in computer drafting was appreciated. and to Kevin Speer (CNRS. Brest), who read an early draft of this paper. A. J. Crawford (University of Tasmania. Hobart) and an anonymous reviewer helped to improve this chapter.

\section{REFERENCES}

Alt, J. C. 1988. Hydrothermal oxide and nontronite deposits on seamounts in the eastern Pacific, Mar. Geol. 81:227-239.

Auzende, J. M., Honza, H., and Scientific Party. 1990. Active spreading and hydrothermalism in North Fiji Basin (SW Pacific): Results of Japanese French cruise Kaiyo 87. Mar. Geophys. Re's. 12:269-283.

Auzende, J. M.. and Urabe, T. 1994. The STARMER French-Japanese Joint Project. 1987-1992, Mar. Geol. 116:1-3.

Bellon, H., Marcelot, G.. Lefêvre. C., and Maillet. P. 1984. Le volcanisme de l'île d'Erromango (République de Vanuatu): Calendrier de l'activité idonnees 40K-40Ar), C. R. Acad. Sci. Paris 299(II):257-262.

Briqueu, L.. and Lancelot. J. R. 1983. Sr isotopes and K, Rh, Sr balance in sediments and igneous rocks from the subducted plate of the Vanuatu (New Hebrides) active margin. Geochim. Cosmochim. Acta 47:191-200.

Carney. J. N., Macfarlane. A., and Mallick, D. I. J. 1985. The Vanuatu island arc: an outline of the stratigraphy, structure and petrology. in The Ocean Basins and Margins. Vol, 7A: The Pacific Ocean (A. E. M. Nairn, F. G. Stehli, and S. Uyeda, eds.). pp. 683-718. Plenum Press. New York.

Charvis, P., and Pelletier. B. 1989 . The northern New Hebrides backarc troughs: History and relation with the North Fiji basin, Tectonophysics 170:259-277. 
Collot, J. Y., Daniel J., and Burne, R. V. 1985. Recent tectonics associated with the subduction/collision of the d'Entrecasteaux zone in the central New Hebrides, Tectonophysics 112:325-356.

Collot, J. Y., and Fisher, M. A. 1988. Crustal structure, from gravity data, of a collision zone in the central New Hebrides island arc, in Geology and Offshore Resources of Pacific Island Arcs-Vanuatu Region (H. G. Greene and F. L. Wong, eds.), Earth Science Ser., Vol. 8, pp. 125-139, Circum-Pacific Council for Energy and Mineral Resources, Houston, TX.

Collot, J. Y., Greene, H. G., Stokking, L., et l'équipe du Leg 134. 1991. Résultats préliminaires du Leg 134 de l'Ocean Drilling Program dans la zone de collision entre l'arc insulaire des Nouvelles-Hébrides et la Zone d'Entrecasteaux, C. R. Acad. Sci. Paris 313(II):539-546.

Collot, J. Y., Greene, H. G., Stokking, L. B., et al. 1992a. Proc. ODP, Init. Repts., 134, Ocean Drilling Program, College Station, TX.

Collot, J. Y., Lallemand, S., Pelletier, B., Eissen, J. P., Glaçon, G., Fisher, M. A., Greene, H. G., Boulin, J., Daniel, J., and Monzier, M. 1992b. Geology of the d'Entrecasteaux-New Hebrides Arc collision zone: Results from a deep submersible survey, Tectonophysics 212:213-241.

Collot, J. Y., and Malahoff, A. 1982. Anomalies gravimétriques et structure de la zone de subduction des Nouvelles-Hébrides, in Contribution à l'étude géodynamique du Sud-Ouest Pacifique, pp. 91-109, Travaux et Documents de l'ORSTOM n ${ }^{\circ} 147$.

Coulon, C., Maillet, P., and Maury, R. C. 1979. Contribution à l'étude du volcanisme de l'arc des NouvellesHébrides: Données pétrologiques sur les laves de l'île d'Efaté, Bull. Soc. Géol. France 7, 21(5):619-629.

Crawford, A. J., Greene, H. G., and Exon, N. F. 1988. Geology, petrology and geochemistry of submarine volcanoes around Epi Island, New Hebrides island arc, in Geology and Offshore Resources of Pacific Island Arcs-Vanuatu Region (H. G. Greene and F. L. Wong, eds.), Earth Science Ser., Vol. 8, pp. 301-327, CircumPacific Council for Energy and Mineral Resources, Houston, TX.

Daniel, J. 1982. Morphologie et structures superficielles de la partie sud de la zone de subduction des NouvellesHêbrides, in Contribution à l'étude géodynamique du Sud-Ouest Pacifique, pp. 39-60, Travaux et Documents de l'ORSTOM n ${ }^{\circ} 147$.

Daniel, J., Gérard , M., Mauffret, A., Boulanger, D., Cantin, B., Collot, J. Y., Durand, J., Fisher, M. A., Greene, H. G., Michaux, P., Pelletier, B., Pezzimenti, A., Renard, V., Schaming, M., and Tissot, J. D. 1989. Déformation compressive d'un bassin intra-arc dans un contexte de collision ride-arc: Le bassin d'Aoba, arc des Nouvelles-Hébrides, C. R. Acad. Sci. Paris 308(II):239-245.

Dubois, J., Dugas, F, Lapouille, A., and Louat, R. 1978. The troughs at the rear of the New Hebrides island arc: Possible mechanisms of formation, Can. J. Earth Sci. 15:351-360.

Dugas, F., Carney, J. N., Cassignol, C., Jezek, P. A., and Monzier, M. 1977. Dredged rocks along a cross-section in the southern New Hebrides island arc and their bearing on the age of the arc, in International Symposium on Geodynamics in South-West Pacific, Nouméa (New Caledonia), 27 August-2 September 1976, pp. 105-116, Editions Technip, Paris.

Dupont, J., and Herzer, R. H. 1985. Effect of subduction of the Louisville Ridge on the structure and morphology of the Tonga arc, in Geology and Offshore Resources of Pacific Island Arcs-Tonga Region (D. W. Scholl and T. L. Vallier, eds.), Earth Science Ser., Vol. 2, pp. 323-332, Circum-Pacific Council for Energy and Mineral Resources, Houston, TX.

Eissen, J. P., Lefèvre, C., Maillet, P., Morvan, G., and Nohara, M. 1991. Petrology and geochemistry of the central North Fiji Basin spreading centre (Southwest Pacific) between $16^{\circ} \mathrm{S}$ and $22^{\circ} \mathrm{S}, \mathrm{Mar}$. Geol. 98:201-239.

Eissen, J. P., Nohara, M., Cotten, J., and Hirose, K. 1994. North Fiji Basin basalts and their magma sources. I: Incompatible element constraints, Mar. Geol. 116:153-178.

Eissen, J. P., Robin, C., and Monzier, M. 1992. Découverte et interprétation d'ignimbrites basiques à Tanna (Vanuatu, SO Pacifique), C. R. Acad. Sci. Paris 315(II):1253-1260.

Falvey, D. A., and Greene, H. G. 1988. Origin and evolution of the sedimentary basins of the New Hebrides arc, in Geology and Offshore Resources of Pacific Island Arcs-Vanuatu Region (H. G. Greene and F. L. Wong, eds.), Earth Science Ser., Vol. 8, pp. 413-442, Circum-Pacific Council for Energy and Mineral Resources, Houston, TX.

Frenzel, G., Mühe, R., and Stoffers, P. 1990. Petrology of the volcanic rocks from the Lau Basin, Southwest Pacific, Geol. Jb D 92:395-479.

Fryer, P., Taylor, B., Langmuir, C. H., and Hochstaedter, A. 1990. Petrology and geochemistry of lavas from the Sumisu and Torishima backarc rifts, Earth Planet. Sci. Lett. 100:161-178.

Gérard, M. 1993. Bassins d'arc et fossés arrière-arc dans un contexte de collision-subduction: l'arc des NouvellesHébrides (Vanuatu). Hydrothermalisme, néogenèses, diagenèse d'une série volcanosédimentaire, Thèse de Doctorat, Université de Paris-Sud, Orsay, France. 
Gérard. M.. Person. A., Récy, J., and Dubois. J. 1987 . Preliminary results of petrological and mineralogical studies of manganesiferous encrustations dredged over the New Hebrides back arc (Vanuatu), E.U.G.-E.G.S. VII. Strasbourg, 13-16 April 1987, Terra Cognita 7:2-3.

Gill, J. B. 1981. Orogenic Andesites and Plate Tectonics. Springer-Verlag, Berlin, Heidelberg. New York.

Gorton. M. P. 1974. The geochemistry and geochronology of the New Hebrides. Ph.D. thesis, Australian National University.

Gorton. M. P. 1977. The geochemistry and origin of Quaternary volcanism in the New Hebrides. Geochim. Cosmochim. Acta 41:1257-1270.

Greene, H. G., and Johnson, D. P. 1988. Geology of the central basin region of the New Hebrides arc inferred from single-channel seismic-reflection data. in Geology and Offishore Resumes of Pacific Island Ars-Vamuatu Region iH G Greene and F I Wong. eds . Farth Science Ser. Vol. 8. pp 177-199. Circum-Pacific Council for Energy and Nineral Resources, Houston. TX.

Greene, H. G., Macfarlane. A.. and Wong. F. L. 1988a. Geology and oftshore resources of Vanuatu-Introduction and summary, in Geology and Offshor Re sources of Pacific lsland Arcs-Vimuatu Re'gion (H. G. Greene. and F. L. Wong, eds. . Earth Science Ser. Vol. 8. pp. 1-25. Circum-Pacific Council for Energy and Mineral Resources. Houston. TX.

Greene. H. G., Macfarlane, A.. Johnson. D. P.. and Crawford, A. J. 1988b. Structure and tectonics of the central New Hebrides arc. in Geology and Offshor Resubres of Pacific Island Arcs-Vinuatu Region (H. G. Greene. and F. L. Wong. eds.). Earth Science Ser., Vol. 8. pp. 377-413, Circum-Pacific Counc1l for Energy and Mineral Resuurces, Houston, TX.

Hawkins, J. W., Lonsdale. P. F. Macdougall, J. D., and Volpe. A. M. 1990. Petrolngy of the axial ridge of the Mariana Trough bacharc spreading center, Earth Planet. Sci. Lett. 100:226-250.

Hawkins, J. W., and Melchior, J. T. 1985. Petrology of Mariana Trough and Lau Basin basalts, J. Geophrs. Res. 90:11,431-11,468.

Hochstaedter. A. G., Gill. J. B.. Kusakahe, M., Newman. S.. Pringle. M.. Taylor, B.. and Fryer, P. 1990a. Volcanism in the Sumisu Rift. I: Major element, wolatile. and stable iscitope geochemistry, Earth Planct. Sci. Lett. 100:179-194.

Hochstaedter, A. G. Gill, J. B.. and Morris, J. D. 1990 b. Volcanism in the Surnisu Rift. Il: Subduction and nonsubduction related components, Earth Planet. Sci. Lett. 100:195-209.

Hoffert, M.. Cheminée. J. L.. Larque. P.. and Person, A. 1987. Dépôt hydrothermal associé au voleanisme sousmarin "intraplaque" oceanique. Prélevements effectués avee Cyana sur le volcan actif de Téahitia. $C . R$. Arad. Sci. Paris 304(1I):829-833.

Holmes, M. L., 1988. Seismic refraction meatsurements in the summit basins of the New Hebrides are, in Giolegy and Offshore Resources of Pacific lsland Arss- Limuan Re'gion iH. G. Greene, and F. L. Wong. eds. I. Earth Science Ser. Vol. 8, pp. 163-176. Circum-Pacitic Council for Energy and Mineral Resiources, Houston. TX.

Huchon, Ph., Gracia, E.. Ruellan. E.. Ioshima. M.. and Auzende, J. M. 1994. Kinematics of active spreading in the central North Fiji Basin (Southwest Pacific), Mar: Geol. 116:69-87.

Ikeda, Y. and Yuasa. M. 1989. Volcanism in nascent back-arc basms behind the Shichito Ridge and adjacent areas in the Izu-Ogasawara arc. northwest Pactic: Evidence for mixing between E-type MORB and island arc magnas at the initiation of backarc rifting. Contrib. Nineral. Petrol. 101:377-393.

Isacks, B. L.. Cardwell. R. K., Chatelain. J. L., Barazangi. M., Marthelot. J. M., Chinn. D., and Louat. R. 1981. Seismicity and tectonics of the central New Hebrides island arc. in Earthugake Prediction: An Intemutionul Review (D. W. Simpson and P. G. Richatrds, eds.), Vol. 4. pp. 93-116. American Geophycical Union Maurice Ewing Series.

Ishizuka, H. Kawanobe, Y., and Sakai. H. 1990. Petrology and geochemistry of volcanic rochs dredged from the Ohinaw a Trough. an active back arc basin, Goochem. J. 24:75-42.

Jarvis, P. A.. Kroenke, L. W. Price, R. C., and Maillet, P. 1993. GLORIA imagery of sea floor structures in the northern North Fiji Basin. Goo-Mar. Lett. 13:90-97.

Johnson. D. P.. Maillet. P., and Price, R. C. 1993. Regional setting of a complex backarc: New Hebrides Arc. northern Vanuatu-eastern Sulomon islands. Geo-Mar. Lett. 13: $\$ 2-89$.

Johnson, K. T. M., and Sinton. J. M. 1990. Petrolngy, tectonic setting. and the formation of backarc basin hasalts in the North Fiji Basin. Geol. th D 92:517-545.

KAIYO 89 Cruise Report. 1990. (KAIYO 89 cruise in the North Fiji Basin and Vanuatu backare troughs, 14 December 1989-13 January 1990). STARMER Cruise Report Vol. V, unpublshed.

Kronke. L. W. 1984. Cenonot tectonic development of the Southwest Pacific, U. N. ESCAP. CCOP/SOPAC Tech. Bull. 0. 
Kroenke, L. W., Smith, R., and Nemoto, K. 1994. Morphology and structure of the seafioor in the northern part of the North Fiji Basin, in Basin Formation, Ridge Crest Processes, and Metallogenesis in the North Fiji Basin (L. W. Kroenke and J. V. Eade, eds.), Earth Science Ser, Vol. 12, pp. 15-25, Circum-Pacific Council for Energy and Mineral Resources, Springer, Heidelberg.

Lallemand, S. E., Malavieille, J., and Calassou, S. 1992. Effects of oceanic ridge subduction on accretionary wedges: experimental modeling and marine observations, Tectonics 11(6):1301-1313.

Leg 126 Scientific Drilling Party. 1989. ODP Leg 126 drills the Izu-Bonin arc, Geotimes 34(10):36-38.

Leg 126 Shipboard Scientific Party. 1989. Arc volcanism and rifting, Nature 342:18-20.

Leg 135 Scientific Party. 1992. Evolution of backarc basins: ODP Leg 135, Lau Basin, EOS, Trans. AGU 73:22.

Louat, R., Hamburger, M., and Monzier, M. 1988. Shallow and intermediate-depth seismicity in the New Hebrides arc: constraints on the subduction process, in Geology and Offshore Resources of Pacific Island ArcsVanuatu Region (H. G. Greene and F. L. Wong, eds.), Earth Science Ser., Vol. 8, pp. 329-356, Circum-Pacific Council for Energy and Mineral Resources, Houston, TX.

Louat, R., and Pelletier, B. 1989. Seismotectonics and present-day relative plate motions in the New HebridesNorth Fiji Basin region, Tectonophysics 167:41-55.

Macfarlane, A., Carney, J. N., Crawford, A. J., and Greene, H. G. 1988. Vanuatu-A review of the onshore geology, in Geology and Offshore Resources of Pacific Island Arcs-Vanuatu Region (H. G. Greene and F. L. Wong, eds.), Earth Science Ser., Vol. 8, pp. 45-91, Circum-Pacific Council for Energy and Mineral Resources, Houston, TX.

Maillet, P., Monzier, M., Eissen, J. P., and Louat, R. 1989. Geodynamics of an arc-ridge junction: the case of the New Hebrides Arc/North Fiji Basin, Tectonophysics 165:251-268.

Maillet, P., Monzier, M., and Lefèvre, C. 1986. Petrology of Matthew and Hunter volcanoes, south New Hebrides island arc (southwest Pacific), J. Volcanol. Geotherm. Res. 30:1-27.

Maillet, P., Monzier, M., Selo, M., and Storzer, D. 1983. The d'Entrecasteaux zone (southwest Pacific), a petrological and geochronological reappraisal, Mar. Geol. 53:179-197.

Matsumoto, T., Iwabuchi, Y., and Maillet, P. 1992. Tectonics in the Vanuatu backarc basin as derived from precise bottom topography, International Geological Congress, Kyoto, Japan, August 1992, Abstracts Volume, p. 36.

Minster, J. B., and Jordan, T. H. 1978. Present day plate motions, J. Geophys. Res. 83:5,331-5,354.

Monjaret, M. C. 1989. Le magmatisme des fossés à l'arrière de l'arc des Nouvelles-Hébrides (Vanuatu) (Campagne SEAPSO 2 du N. O. Jean Charcot). Implications géodynamiques. Chronologie, pétrologie, géochimie, Thèse de Doctorat, Université de Bretagne Occidentale (UBO), Brest, France.

Monjaret, M. C., Bellon, H., and Maillet, P. 1991. Magmatism of the troughs behind the New Hebrides island arc (RV Jean-Charcot SEAPSO 2 cruise): K-Ar geochronology and petrology, J. Volcanol. Geoth. Res. 46: $265-280$.

Monjaret, M. C., Bellon, H., Maillet, P., and Récy, J. 1987. Le volcanisme des fossés arrière-arc des NouvellesHébrides (campagne SEAPSO Leg 2 du N/O Jean-Charcot dans le Pacifique Sud-Ouest): Datations K-Ar et données pétrologiques préliminaires, C. R. Acad. Sci. Paris 305(II):605-609.

Monzier, M., Collot, J. Y., and Daniel, J. 1984a. Carte bathymétrique des parties centrale et méridionale de l'arc insulaire des Nouvelles-Hébrides, ORSTOM, Paris.

Monzier, M., Maillet, P., and Dupont, J. 1991. Carte bathymétrique des parties méridionales de l'arc insulaire des Nouvelles-Hébrides et du bassin Nord-Fidjien, Institut Français de Recherche Scientifique pour le Développement en Coopération (ORSTOM), Paris.

Monzier, M., Maillet, P., Foyo Herrera, J., Louat, R., Missègue, F., and Pontoise, B. 1984b. The termination of the southern New Hebrides subduction zone (southwestern Pacific), Tectonophysics 101:177-184.

Nakada, S., Maillet, P., Monjaret, M. C., Fujinawa, A., and Urabe, T. 1994. High-Na dacite from the Jean-Chareot Trough (Vanuatu), Southwest Pacific, Mar. Geol. 116:197-213.

Nakamura, N., 1974, Determination of REE, $\mathrm{Ba}, \mathrm{Fe}, \mathrm{Mg}, \mathrm{Na}$ and $\mathrm{K}$ in carbonaceous and ordinary chondrites, Geochim. Cosmochim. Acta 38:757-773.

Nohara, M, Hirose, K., Eissen, J. P., Urabe, T., and Joshima, M. 1994. The North Fiji Basin basalts and their magma sources. II: Sr-Nd isotopic and trace element constraints, Mar. Geol. 116:179-195.

Nojiri, Y., and Ishibashi, J. 1991. Hydrothermal plumes observed in the North Fiji Basin, in STARMER Symposium, Geology and Biology of the Rift System in the North Fiji and Lau Basins, 7-11 Feb. 1991, Noumea, New Caledonia, Abstracts Volume, p. 41.

Odin, G. S., and Desprairies, A. 1988. Nature and geological significance of celadonite, in Green Marine Clays (G. S. Odin, ed.), Developments in Sedimentology 45, Elsevier, Amsterdam.

Pearce, J. A. 1983. The role of sub-continental lithosphere in magma genesis at destructive plate margins, in 
Continental Basalts and Mantle Xenoliths (C. J. Hawkesworth and M. J. Norry, eds.), pp. 230-249, Nantwich, Shiva.

Pelletier, B., Charvis, P., Daniel, J., Hello. Y., Jamet, F., Louat, R., Nanat. P., and Rigolot, P. 1988. Structure et linéations magnétiques dans le coin Nord-Ouest du bassin Nord-Fidjien: résultats préliminaires de la campagne Eva 14 (août 1987), C. R. Acad. Sci. Paris 306(II):1247-1254.

Pelletier, B., and Dupont. J. 1990a. Erosion, accrétion, extension arrière-arc et longueur du plan de subduction le long de la marge active des Kermadec. Pacifique Sud-Ouest. C. R. Acad. Sci. Paris 310(II):1657-1664.

Pelletier, B.. and Dupont. J. 1990b. Effets de la subduction de la ride de Louisville sur l'arc des Tonga-Kermadec, Oceanol. Acta 10:57-76.

Pelletier, B., Lafoy, Y.. and Missègue. F. 1993a. Morphostnucture and magnetic fabric of the northwestern North Fiji Basin, Geophys. Res. Leti. 20012i:115i-1154.

Pelletier. B., and Louat, R. 1989. Mouvements relatifs des plaques dans le Sud-Ouest Pacifique, C. R. Actd. Sci. Paris 308(II): $123-130$

Pelletier, B., Missègue. F., Lafoy, Y., Mollard, L., Decourt, R., Dupont, J., Join, Y., Perrier, J.. and Récy, J. $1993 \mathrm{~b}$. Extrêmités nord du hassin Nord-Fidjien et des fossés arrière-arc des Nouvelles-Hébrides: morphostructure et signature magnétique, C. R. Acad. Sci. Paris 316(II):637-644.

Person. A. 1980. Concrétions polymétalliques des sédiments de l'océan Pacifique équatorial-zone nord est: étude diffractométrique du comportement aux contraintes thermiques de la todorokite, Bull. Soc. Fr. Mineral. Cristallogr: $103(2)$.

Picard, C., Monzier. M., Eissen, J. P.. and Rohin. C. 1995. Concomitant evolution of tectonic environment and magma geochemistry, Ambrym volcano (Vanuatu-New Hebrides arc). in Volcanism Associated with Extension at Consuming Plate Margins (J. L. Smellie, ed.), Geological Society Special Publication No. 81. pp. $135-154$

Pontoise, B., Latham. G. V., and Ibrahim, A. B. K. 1982. Sismique réfraction: structure de la croute aux NouvellesHébrides, in Contribution à l'étude gêdonnamiqué du Sud-Ouest Pacitique. pp. 79-90. Travaux et Documents de l'ORSTOM, n'147.

Price. R. C., and Kroenke, L. W. 1991. Tectonics and magma genesis in the northern North Fiji Basin, Mar. Geol. 98:241-258

Price, R. C.. Johnson. L. E. , and Crawford, A. J. 1990. Basalts of the North Fiji Basin: the generation of back are basin magmas by mixing of depleted and enriched mantle sources, Contrib. Mineral. Petrol. 105:10h-121.

Price, R. C., Maillet, P., and Johnson, D. P. 1993. Interpretation of GLORIA side-scan sonar imagery for the Coriolis troughs of the New Hebrides backarc, Geo-Mar. Lett. 13:71-81.

Puech, J. L.. and Reichenfeld, C. 1969. Etudes bathymétriques dans la région des îles Erromango. Tanna et Anatom (Nouvelles-Hébrides), C. R. Acad. Sci. Puris 208:1259-1201.

Récy, J., Charvis. P.. Ruellan. E.. Monjaret. M. C., Gérard, M., Auclair, G., Baldassari. C., Boirat. J. M.. Brown. G. R.. Butscher, J.. Collot. J. Y.. Daniel, J.. Louat, R.. Monzier, M.. and Pontoise. B. 1986. Tectonique et volcanisme sous-marin à l'arrière de l'arc des Nouvelles-Hebrides (Vanuatul: résultats préliminaires de la campagne SEAPSO (leg 2) du N/O Jean Charcot. C. R. Acad. Sci. Paris 303(II):685-690.

Récy. J., Pelletier. B., Charvis, P.. Gérard. M.. Monjaret, M. C., and Maillet. P. 1990. Structure, âge et origine des fossés arrière-arc des Nouvelles-Hébrides (Sud-Ouest Pacifique). Océanol. Acta 10:165-182.

Robin, C., Eissen, J. P.. and Monzier. M. 1994. Ignimbrites of basaltic andesite and andesite compositions from Tanna (New Hebrides Arc), Bull. Wolcunol. 56:10-22.

Robin. C., Monzier. M., Eissen. J. P., Picard, C., and Camus, G. 1991. Coexistence de lignées HK et MK dans les pyroclastites associées à la caldera d'A mbrym (Vanuatu-Arc des Nouvelles-Hébrides), C. R. Acud. Sci. Parts 313(II): $1425-1+32$.

Roca. J. L. 1978. Contribution a l'étude petrologique et structurale des Nouvelles-Hébrides. Thèse de 3ème cycle. Université des Sciences et Techniques du Languedoc. Montpellier. France.

Sage, F.. and Charvis, P. 1991. Structure profonde de la transition are insulaire-bassin marginal dans le nord des Nouvelles-Hébrides (Vanuatu. Pacifique sud-ouest), C. R. Arad. Sci. Paris 313(II):41-48.

Saunders, A. D., and Tarney, J. 1984. Geochemical characteristics of hasaltic volcanism within backare basins, in Marginal Basins Geology: Whlcanism and Associated Sedimemany and Tectonic Processes in Medern and Ancient Marginal Basins (B. P. Kokelitar and M. F. Howels, eds.), pp. 59-76. Blackwell Scientitic, Cambridge. MA.

SAVANES 91-92 Cruise Report. 1992. (SAVANES $91-92$ cruise with Cyanu submersible in the northern Vanuatu backarc troughs). 19 December 1991-12 January 1992, STARMER Cruise Report Vol. VIII. unpublished.

Sibuet, J. C., Letouzey. J.. Barbier. F. Charvet. J., Foucher, J. P.. Hilde. T. W. C.. Kimura. M.. Ling-Yun, C. 
Marsset, B., Muller, C., and Stephan, J. F. 1987. Backarc extension in the Okinawa trough, J. Geophys. Res. 92:14,041-14,063.

Sigurdsson, I. A., Kamenetsky, V. S., Crawford, A. J., Eggins, S. M., and Zlobin, S. K. 1993. Primitive island arc and oceanic lavas from the Hunter Ridge-Hunter fracture zone. Evidence from glass, olivine and spinel compositions, Mineral. Petrol. 47:149-169.

Sinton, J. M., Price, R. C., Johnson, K. T. M., Staudigel, H., and Zindler, A. 1994. Petrology and geochemistry of submarine lavas from the Lau and North Fiji back-arc basins, in Basin Formation, Ridge Crest Processes, and Metallogenesis in the North Fiji Basin (L. W. Kroenke and J. V. Eade, eds.), Earth Science Ser., Vol. 12, pp. 155-177, Circum-Pacific Council for Energy and Mineral Resources, Springer, Heidelberg.

Sun, S.-s., and McDonough, W. F. 1989. Chemical and isotopic systematics of oceanic basalts: implications for mantle composition and processes, in Magmatism in the Ocean Basins (A. D. Saunders and M. J. Norry, eds.), pp. 313-345, Geological Society Special Publication No. 42.

Tatsumi, Y., Murasaki, M., and Nohda, S. 1992. Across-arc variation of lava chemistry in the Izu-Bonin arc: identification of subduction components, J. Volcanol. Geotherm. Res. 49:179-190.

Taylor, B. 1992. Rifting and the volcanic-tectonic evolution of the Izu-Bonin-Mariana arc, in Proc. ODP, Sci. Results Vol. 126 (B. Taylor, K. Fujioka et al., eds.), pp. 627-651, Ocean Drilling Program, College Station, TX.

Taylor, B., Brown, G., Fryer, P., Gill, J. B., Hochstaedter, A. G., Hotta, H., Langmuir, C. H., Leinen, M., Nishimura, A., and Urabe, T. 1990. ALVIN-Sea Beam studies of the Sumisu Rift, Izu-Bonin arc, Earth Planet. Sci. Lett. 100:127-147.

Taylor, B., K. Fujioka, K., et al. 1992. Proc. ODP, Sci. Results, Vol. 126: College Station, TX (Ocean Drilling Program).

Taylor, B., Klaus, A., Brown, G. R., and Moore, G. F. 1991. Structural development of Sumisu rift, Izu-Bonin arc, J. Geophys. Res. 96:16,113-16,129.

Thorpe, R. S (Editor). 1982. Andesites, Orogenic Andesites and Related Rocks, Wiley, New York.

Tiffin, D. L. 1993. Tectonic and structural features of the Pacific/Indo-Australian plate boundary in the North FijiLau Basin regions, southwest Pacific, Geo-Mar, Lett. 13:126-131.

Usui, A., Mellin, T. A., Nohara, M., and Yuasa, M. 1989. Structural stability of marine $10 \AA$ manganates from the Ogasawara (Bonin) arc: implication for low-temperature hydrothermal activity, Mar. Geol. 86:41-56.

Vallot, J. 1984. Volcanites draguées au large de l'arc insulaire des Nouvelles-Hébrides. Implications pétrologiques, Thèse de 3ème cycle, Université de Paris-Sud, Orsay, France.

Von Stackelberg, U., and von Rad, U. 1990. Geological evolution and hydrothermal activity in the Lau and North Fiji basins (SONNE cruise SO-35) - a synthesis, Geol. Jb D 92:629-660.

Weaver, C. E. 1989. Clays, Muds and Shales, Developments in Sedimentology, Vol. 44, Elsevier, Amsterdam. Weissel, J. K., and Karner, G. D. 1989. Flexural uplift of rift flanks due to mechanical unloading of the lithosphere during extension, J. Geophys. Res. 94:13,919-13,950.

Wilson, M. 1989. Igneous Petrogenesis, A Global Tectonic Approach, Unwin Hyman, London. 